NBER WORKING PAPER SERIES

\title{
WHAT HAS BEEN HAPPENING TO UK INCOME INEQUALITY SINCE THE MID-1990S? ANSWERS FROM RECONCILED AND COMBINED HOUSEHOLD SURVEY AND TAX RETURN DATA
}

\author{
Richard V. Burkhauser \\ Nicolas Hérault \\ Stephen P. Jenkins \\ Roger Wilkins \\ Working Paper 21991 \\ http://www.nber.org/papers/w21991 \\ NATIONAL BUREAU OF ECONOMIC RESEARCH \\ 1050 Massachusetts Avenue \\ Cambridge, MA 02138 \\ February 2016
}

This research is supported by an Australian Research Council Discovery Grant (award DP150102409). In addition, Burkhauser over the past three years has received funding in excess of $\$ 5,000$ from the American Enterprise Institute; the Employment Policies Institute; the Lynde and Harry Bradley Foundation Graduate and Post-Graduate Fellowship Program; the Michigan Retirement Research Consortium (from the Social Security Administration), and the Russell Sage Foundation. Hérault over the past three years has received funding in excess of $\$ 5,000$ from an Australian Research Council Discovery Grant. Jenkins over the past three years has received funding in excess of \$5,000 from the Research Centre on Micro-Social Change at the Institute for Social and Economic Research by the University of Essex and the UK Economic and Social Research Council (award ES/L009153/1). Wilkins over the past three years has received funding in excess of $\$ 5,000$ from the Australian Government Department of Social Services, the Australian Fair Work Commission, and the Australian Workforce and Productivity Agency. The findings and views reported in this paper are those of the authors and should not be attributed to any of the above-mentioned organizations. For helpful discussions about the World Top Incomes Database and about the HBAI data and SPI adjustments, we thank Tony Atkinson and Facundo Alvaredo, and Peter Matejic (DWP), respectively. For comments on an early draft, we thank Tony Atkinson, Peter Matejic, Brian Nolan, Holly Sutherland, and the LSE Quantitative Social Policy reading group. The views expressed herein are those of the authors and do not necessarily reflect the views of the National Bureau of Economic Research.

NBER working papers are circulated for discussion and comment purposes. They have not been peerreviewed or been subject to the review by the NBER Board of Directors that accompanies official NBER publications.

(C) 2016 by Richard V. Burkhauser, Nicolas Hérault, Stephen P. Jenkins, and Roger Wilkins. All rights reserved. Short sections of text, not to exceed two paragraphs, may be quoted without explicit permission provided that full credit, including (C) notice, is given to the source. 
What has Been Happening to UK Income Inequality Since the Mid-1990s? Answers from

Reconciled and Combined Household Survey and Tax Return Data

Richard V. Burkhauser, Nicolas Hérault, Stephen P. Jenkins, and Roger Wilkins

NBER Working Paper No. 21991

February 2016

JEL No. C81,D31

\section{ABSTRACT}

Estimates of UK income inequality trends differ substantially according to whether estimates are based on household survey data (used for official statistics) or tax return data (used in the top incomes literature). We reconcile differences in variable definitions and combine survey and tax return data in order to take advantage of the much better coverage of top incomes in the latter, and provide improved estimates of UK inequality trends since the mid-1990s. We show there was a marked increase in income inequality in the early 2000s that survey-based estimates do not reveal, and our conclusions are robust to changes in the definitions of income, income-sharing unit, and summary inequality measure. In addition, our reconciled and combined data provide more comparable estimates of UK-US inequality trends than the top incomes literature to date.

Richard V. Burkhauser
Cornell University
Department of Policy Analysis
\& Management
259 MVR Hall
Ithaca, NY 14853-4401
and University of Melbourne
and also NBER
rvb1@cornell.edu
Nicolas Hérault
Melbourne Institute of Applied Economic
and Social Research
Level 5, 111 Barry St
Carlton, VIC 3053
nherault@unimelb.edu.au

Stephen P. Jenkins

Department of Social Policy

London School of Economics

and Political Science

Houghton Street

London WC2A 2AE

United Kingdom

s.jenkins@1se.ac.uk

Roger Wilkins

Melbourne Institute of Applied Economic

and Social Research

University of Melbourne

Faculty of Business and Economics Building

5th floor

Victoria 3010, Australia

r.wilkins@unimelb.edu.au 


\section{Introduction}

Income inequality levels and trends are increasingly a subject of public discussion and the subject of much analysis by economists and other social scientists. Major books about inequality receive public attention (e.g. Atkinson 2015, Piketty 2014). Productive debate about what is happening to inequality requires reliable estimates and yet the two main sources of information - household surveys and tax return data - can provide very different estimates of inequality trends. We address this problem, demonstrating that it is possible to reconcile and combine tax return and survey data in a manner that exploits the strengths of each source, and thereby provide better answers to questions such as: what has been happening to income inequality since the mid-1990s?

Household survey data are the most commonly used source for monitoring income inequality levels and trends in most rich countries. Survey data are used to derive official statistics in countries such as the UK and the USA and elsewhere; they are the basis of crossnational comparative studies such as those undertaken by the $\operatorname{OECD}(2008,2011,2015)$; and they are the source for most of the distributional analysis by other researchers. The incomesharing unit in virtually all these studies is the household and the income definition is disposable (post-tax post-transfer) income, adjusted for differences in household size and composition using an equivalence scale. Inequality is typically summarised using indices such as the Gini coefficient that are based on the entire income distribution.

A long-standing challenge to survey-based estimates is that they do not provide the full picture about inequality and its trends because they capture top incomes inadequately or not at all. In contrast, the personal tax return data used by the top income shares literature do a much better job of capturing top incomes. This benefit is gained at the cost of being constrained to use the definitions of income and income-sharing unit used by each country's tax administration (definitions that differ from the survey-based ones), and being restricted to summary inequality measures that do not incorporate differences across the full income range (i.e. top income shares). Survey-based studies do not face these problems.

The need to reconcile and combine data is demonstrated by Figure 1. The figure shows income inequality trends in the UK over the last five decades using commonly-used measures derived from tax return data (the share of total income received by the richest 1\%) and from household survey data (the Gini coefficient and $p 90 / p 10$, the ratio of the $90^{\text {th }}$ percentile to the $10^{\text {th }}$ percentile). We express each measure relative to its value in 1962 so that proportionate changes in the measures can be readily compared. The survey data estimates 
are the same as those provided by UK's official income distribution statistics (the annual 'Households Below Average Income’ reports), and the tax return data are derived from the World Top Incomes Database which in turn derives estimates from the Survey of Personal Incomes (the UK tax return data). As we explain later, the definitions of income and the income-sharing unit differ in each source.

It is immediately apparent that UK income inequality trends differ substantially depending on which source (and hence which inequality measure) is used. ${ }^{1}$ Between 1962 and 1978, the top $1 \%$ share fell by almost a third, but the Gini coefficient and $p 90 / p 10$ by only around 5\%. The increase in inequality between 1978 and 1991 according to the top 1\% share measure is twice the increase in the Gini (80\% compared to 42\%). The striking contrasts between the series persist in more recent years. Between 1991 and 2007, the top 1\% share rose by $50 \%$, but the Gini coefficient rose by only $5 \%$ and the $p 90 / p 10$ actually fell by $5 \%$.

By referring to official estimates based on the survey data (essentially those shown in Figure 1), Young (2015) can state that 'there's not much evidence that the United Kingdom became more unequal in the last parliament'. Referring to the top income share estimates derived from tax return data, Atkinson writes that 'the last quarter of the twentieth century saw an almost complete reversal of the decline in observed inequality at the top that had taken place in the preceding 25 years' (2007: 98). Figure 1 shows that this U-shaped trend is not apparent for survey-based estimates. Roser (2015) comments that '[i]f anything, income inequality has actually fallen in the UK over the past 25 years', though he also goes on to remark that 'the incomes of the poor in the UK are growing as fast as the incomes of the rich, apart from the top 1\%, whose incomes are racing away’. Roser bases his conclusion on estimates from both survey and tax data (as in Figure 1), but he does not point out that the definitions employed by the two data sources differ. ${ }^{2}$

In this paper, we provide improved estimates of trends in UK income inequality since the mid-1990s, reconciling survey and tax return data definitions and combining data to derive new series. Reconciliation of definitions is essential because, otherwise, like is not being compared with like. Data combination takes account of under-coverage in the survey

\footnotetext{
${ }^{1}$ Estimates of US income inequality trends also differ substantially depending on whether survey and tax return data are used: see Appendix Figure A1.

2 The closest to a systematic comparison to date of survey and tax data estimates for the UK is provided by Brewer, Sibieta, and Wren-Lewis (2007) who, for example, compare the growth in average annual income between 1996/97 and 2004/05 for each percentile within the richest tenth (Table 14). However they do not compare like with like because they use the standard source-specific definitions of income and income-sharing unit.
} 
data.

The UK tax return data files contain relatively few variables and it is not possible to link individuals belonging to the same family or household. As a consequence, we cannot use the tax data to construct measures based on the definitions of income and income-sharing unit (family and household) used by the UK official income distribution statistics, based on household survey data, and which are essentially the same as those used by Eurostat and the OECD. However, because of the wealth of detail available in the surveys and access to the unit record data, we are able to do an innovative cross-walk from the survey-based definitions of income and income-sharing unit to the tax return data definitions. With this reconciliation, we are able to combine data on a like-to-like basis and derive new income inequality series. And we can explore the consequences of using different definitions and different summary inequality measures.

In Section 2, we provide key details about the tax return and household data that we use and explain how we reconcile and combine the two sources, with further information provided in Appendices. As we explain, the UK Department for Work and Pensions who produce the official survey-based inequality estimates already employ a limited form of data combination in the form of an 'SPI-adjustment'. Our data combination procedure uses similar ideas but it is more extensive and we benchmark it against top income share estimates from the World Top Incomes Database.

Our results are presented in Sections 3-5. First, we show how poorly existing survey data estimates of top income shares track their tax return data counterparts. Second, and by contrast, we show how with our combined data, we can derive estimates of top income shares that are almost identical to those reported by the World Top Incomes Database. Then we exploit the flexibility of the survey data and employ our combined data to analyse the implications of changing definitions of income and income-sharing unit, and to compare top income share estimates in the UK and the USA using more harmonised definitions. We show that conclusions about transatlantic differences in top income shares depend on which income group one considers; but the UK trends are similar whichever distributional definitions we employ.

Finally, we use our combined data to examine inequality trends using summary inequality measures that take into account income differences over the full income range (Gini coefficients and generalized entropy indices) rather than top income shares. Because the combined data take greater account of changes in top incomes than do the survey data reference point, our estimate of the increase in the Gini coefficient between fiscal years 
2003/04 and 2007/08 is greater according to the former than the latter. Using more topsensitive inequality measures shows an even sharper inequality rise. These trends differ from those implied by the survey-based data underlying the UK official income distribution statistics (cf. Figure 1).

\section{Data sources and variables: reconciliation and combination}

\subsection{Tax return data: the Survey of Personal Incomes and the World Top Incomes Database}

In the UK, unit record income tax return data have been made available in the Survey of Personal Incomes (SPI) since the mid-1990s. It is these data, as well as published tabulations from the SPI and from supertax and surtax returns for earlier years, that Atkinson (2005) used in his pioneering analysis of trends in UK top income shares since 1908. Atkinson's methods are similar to those of Piketty (2003), who estimated top income shares in France. See also Piketty and Saez (2003) on top income shares in the USA. Atkinson, Piketty, and Saez (2011) survey the methodology, main findings, and perspectives emerging from the research projects using personal income tax record data. Output from the 28 country studies to date is now available in the World Top Incomes Database (WTID), updated each year, with top income share estimates and associated metadata such as control totals freely downloadable (Alvaredo, Atkinson, Piketty, and Saez 2015).

The SPI does not contain the universe of all income tax returns. Each year's SPI observations are a stratified sample of administrative records for individuals who could be liable to UK tax, with the sample drawn from three databases. The first, 'COP', currently contributes over half the SPI records, and covers employees and occupational pension recipients with a Pay-As-You-Earn record who do not also have a self-assessment record. The second database, 'CESA', covers individuals with self-employment, rental or untaxed investment income (and company directors, those subject to higher rate tax and other people with complex tax affairs), and currently contributes around $40 \%$ of SPI cases. The third database, contributing relatively few cases, covers individuals without COP or CESA records who have had too much tax deducted at source and who claim repayment. Sampling fractions vary substantially within and between databases (and hence so too do the SPI grossing-up weights). The total number of individuals in the SPI has increased steadily over time, from around 57,000 individuals in 1995/96 to nearly 677,500 in 2010/11, corresponding to around 
32 million taxpayers. For further details, see the documents accompanying HM Revenue and Customs KAI Data, Policy and Co-ordination (2014) and corresponding documentation for previous years' data.

The principal variables available refer to gross income (total taxable income from the market plus taxable government transfers, and before the deduction of income tax), and net income (gross income after the deduction of tax). We focus on the pre-tax gross income variable because the WTID and the top income shares literature use this measure.

We cannot derive top income share estimates directly from the SPI unit record data because the SPI does not cover all individuals in the UK population or all of their income. To derive estimates of top income shares that refer to shares in total income among all individuals aged 15 years or more, the WTID uses external population and income control totals for each year, i.e. estimates of the total number of individuals aged 15 or more, and of the total income held by them. For 2009 and later years, the WTID derives its control totals for income from the national accounts (Atkinson 2012). For earlier years, total income is derived from income tax statistics and estimates of the income of those tax units not covered (Atkinson 2007, Atkinson and Ooms 2015). WTID control totals for the population aged 15 and over come from the Office for National Statistics mid-year population estimates (Atkinson 2012). We use the WTID control totals throughout this paper.

\subsection{Household survey data: the Family Resources Survey, and Households Below Average Income subfiles}

For analysis of the UK income distribution, the most-commonly-used data source is the Family Resources Survey (FRS), a large cross-sectional household survey, and the accompanying subfiles of derived income variables called the Households Below Average Income (HBAI) dataset. ${ }^{3}$ The Department for Work and Pensions (DWP) administers the FRS, and DWP staff produce the HBAI subfile that they use to derive the UK's official

\footnotetext{
${ }^{3}$ The first editions of HBAI data were derived from the Family Expenditure Survey (now called the Living Costs and Food Survey, LCFS), a smaller survey less focused on collection of income data than the FRS. The FRS-based HBAI series refer to fiscal (tax) years 1994/95 onwards. (The fiscal year runs from April through to the following March.) The UK income distribution statistics incorporated in the EU's cross-national database EU-SILC are derived by the UK Office for National Statistics (ONS) using what was formerly known as the General Household Survey (now the General Lifestyle Survey) but have recently switched to using the FRS. ONS uses the LCFS for its annual article on the effects of taxes and benefits on household incomes (see e.g. ONS 2015). In neither case does the ONS make any adjusts to better account for under-coverage of top incomes whereas the HBAI does (we explain the HBAI's 'SPI-adjustment' later). The UK Gini coefficient estimates in EU-SILC differ markedly from those in the HBAI: see Jenkins (2015).
} 
income distribution statistics published annually. ${ }^{4}$ Despite its label, the HBAI provides information about the income distribution as a whole.

A major shortcoming of household surveys in general, and the UK FRS in particular, is their inability to fully capture income in the top ranges of the income distribution because of non-coverage of top income earners or under-reporting by those who respond. Atkinson, Piketty, and Saez (2011) provide the most striking example of this issue to date. Referring to the USA, they state that 'the top percentile plays a major role in the increase in the Gini over the last three decades and [Current Population Survey] data that do not measure top incomes fail to capture about half of this increase in overall inequality' (2011: 32).

Under-coverage at the top is an issue that has long exercised the producers of the UK's HBAI statistics and, each year since 1992, the derived variables in the HBAI subfile accompanying the basic survey dataset have contained an 'SPI-adjustment' to 'improve the quality of data on very high incomes and combat spurious volatility' (Department of Social Security 1996: 23). The SPI-adjustment substitutes survey income values for a small number of very rich individuals with values derived from unit record tax return data contained in the Survey of Personal Incomes (SPI) and also recalibrates the survey grossing-up weights (as we discuss in more detail later). We use the term HBAI-SPI data to refer to these DWP-produced variables and to distinguish them from the HBAI-SPI2 data which are those that we derive using an alternative SPI adjustment procedure. Later, we compare estimates of top income shares and other inequality measures and their trends using the FRS, the HBAI-SPI, and HBAI-SPI2 series.

This paper addresses the problem that the HBAI-SPI and the SPI-based WTID series use different definitions of income and of the income-sharing unit. The principal measures in the HBAI-SPI refer to household net (or 'disposable') income, i.e. the sum over all individuals within a household of all income from the market plus government cash transfers and after the deduction of personal income taxes and social security contributions. The definitions in the SPI reflect the administration of the UK personal income tax system, which has been individual-based since 1990: the data used by WTID refer to the gross incomes of adult individuals, where gross income is market income plus most government cash transfers.

The public-release FRS files contain a large number of income variables, but the additional variables provided in the separately-released HBAI subfiles are the primary data

\footnotetext{
${ }^{4}$ The most recent edition is Department for Work and Pensions (2015) covering fiscal years 1994/95 through 2013/14. The Institute for Fiscal Studies, who are contracted by the DWP to check its HBAI calculations, produce their own annual report based on the data. The most recent edition is Belfield et al. (2015).
} 
source of analysis of the UK income distribution and its trends. There are income variables in the HBAI subfiles that incorporate a number of adjustments by DWP staff to improve the validity of the measures (for brevity, we refer to these as the HBAI variables). In addition, the HBAI subfiles contain another set of variables incorporating a further modification - the SPI adjustment. It is these 'HBAI-SPI' variables that are used to produce the official income distribution statistics and the ones most commonly-used by other researchers (cf. Figure 1).

The income statistics that the DWP publishes (such as Department for Work and Pensions 2015) are based on a specific income distribution definition: net (i.e. disposable) household income adjusted for size and composition using the modified-OECD scale, with each individual attributed the equivalised net income of the household to which s/he belongs. ${ }^{5}$ However, access to unit record data allows researchers like us to change the definitions of income and the income-sharing unit, though the scope to do so is constrained by which of the DWP's derived variables are released in the files (and this has changed over time).

The income variables that we use are listed in Table 1 . There are three income definitions (market, gross and net income) and three income-sharing units (the individual, the family, and the household). ${ }^{6}$ We distinguish between the variables made available to researchers - those that come from the survey directly or the DWP's calculations - and the additional variables that we have been able to construct. We discuss the available variables in the next subsection and our constructed ones in section 2.4.

[Table 1 near here]

\subsection{Households Below Average Income data and the SPI adjustment}

The SPI adjustment to each year's HBAI data consists of two elements. One, in order to include more top income, the DWP replaces the individual incomes of a small number of very rich individuals in the FRS with individual incomes they derive from the SPI. Two, to improve representation of top income individuals per se, the survey weights are modified slightly. The new weights use the SPI-derived numbers of very rich individuals as control totals alongside the other control totals used to create the weights for FRS and non-SPIadjusted HBAI data (Department for Work and Pensions 2010, Appendix 2).

\footnotetext{
${ }^{5}$ The headline household net income 'before the deduction of housing costs' measure is essentially the same as that used by Eurostat and the OECD for cross-national comparisons and accords with the recommendations of international bodies such as the Canberra Group (2011).

${ }^{6}$ For brevity, we refer throughout to the 'family', i.e. the nuclear family. More specifically, our family definition is the 'benefit unit', which is the definition of the family used in the UK when assessing benefit eligibility and by household surveys. See Department for Work and Pensions (2015: Annex 5) for details.
} 
To implement the first element, DWP staff derive annual income variables for each adult to match the SPI annual income definition. ${ }^{7}$ They use four different high-income thresholds to determine an FRS individual's eligibility, depending on whether the individual is a pensioner or not, and whether resident in Great Britain or Northern Ireland. (This implies that individuals subject to the SPI adjustments are not necessarily the individuals with the highest incomes.) For example, in 2012/13, 'non-pensioners in Great Britain are subject to the SPI adjustment if their gross income exceeded $£ 236,694$ per year ( $£ 131,166$ per year in Northern Ireland) and pensioners in Great Britain are subject to the SPI adjustment if their gross income exceeded £73,631 per year (£60,088 per year in Northern Ireland)' (Department for Work and Pensions 2014: 11).

The DWP adjusts the thresholds each year (see Appendix Table B1 for a list of all thresholds) and they have changed the adjustment rule slightly over time. Most notably, a change was introduced in 2009/10 to base 'the SPI adjustment methodology [...] on adjusting a fixed fraction of the population rather than on adjusting the incomes of all those individuals with incomes above a fixed cash terms level. This should prevent an increasing fraction of the dataset being adjusted' (Department for Work and Pensions 2010: 242). The DWP introduced further change in 2009/10, basing the threshold for non-pensioners on net of tax income rather than gross income. SPI adjustment rules were also modified when the FRS expanded its coverage to also include respondents from Northern Ireland from 2002/03. (Previously, the data covered Great Britain only, i.e. England, Wales, and Scotland.)

The SPI adjustment method and its changes over time have resulted in the number of individuals in the HBAI subject to adjustment varying from year to year. Focusing on individuals aged 15 years or more (the population included in WTID analyses), between 45 and 175 individuals were subject to the SPI adjustment each year between 1994/95 and 2012/13, representing between $0.12 \%$ and $0.52 \%$ of the weighted adult population. See Appendix Table B2 for details.

Once an FRS individual eligible for the SPI adjustment is identified, his or her individual income is replaced by the average SPI income above the high-income threshold

\footnotetext{
${ }^{7}$ Most FRS income questions ask about the amount last received (around the time of the interview) or the 'usual' amount, and also the period to which the payment refers. These variables are used to create consistent 'weekly' amounts pro rata - it is these that are in the HBAI subfiles. Because FRS interviews occur throughout the year, HBAI income values are also adjusted to a common date using a within-year price index to account for inflation. For the SPI adjustment (and for our derivations), these adjusted weekly amounts are multiplied by $365 / 7$ to derive annual amounts (366/7 in leap years).
} 
among SPI respondents with the same pensioner-location status as the FRS individual. ${ }^{8}$

Because SPI data take longer to become available than the survey data, the SPI income values used for the adjustment for a given year are based on projections made by HMRC staff using SPI data from two years earlier. (The projection method is undocumented.)

After the individual-level income imputations, DWP statisticians recalculate incomes at the family (benefit unit) and household levels. The official income distribution statistics use these SPI-adjusted household income variables.

\subsection{Constructing the missing individual-level HBAI and HBAI-SPI variables}

Individual-level income variables are, for the most part, not available in the HBAI and HBAISPI public-use datasets: see Table 1. The exception is individual-level gross income, which is available but only from 2005/06. Here we explain how we constructed a full set of individuallevel market and gross income variables for the whole period.

The FRS documentation lists all income components that enter into the computation of each FRS income variable. By contrast, the HBAI subfile documentation is limited and does not explain the construction of all its new income variables. ${ }^{9}$ However, some income components are provided in the files and we are able to reconstruct some of the HBAI and HBAI-SPI income variables by adding up the relevant components. For example, government transfers are provided for each income series so that it is possible to construct market income variables at all three income-sharing unit levels.

To obtain HBAI individual-level income variables, we proceed in two steps. From the FRS, we extract the share of family income accruing to each unit's adult member. ${ }^{10}$ We do this separately for gross and market incomes. We then apply these shares to the HBAI family gross and market incomes to obtain our new HBAI individual gross and market income variables. Assuming that individuals' income shares within each family are left unchanged by the HBAI adjustments, this process ensures that the derived HBAI individual income series

\footnotetext{
${ }^{8}$ Because of subsequent re-incorporation of individual-specific survey information after the SPI adjustment, SPI-adjusted individuals in the same group may not have exactly the same post-adjustment individual income in the HBAI-SPI data. For example, according to internal DWP documentation, 'we also add back in other deductions ... but exclude personal pension payments ... as these are not included in the SPI definition of net income. We also take out any housing benefit as this is arbitrarily allocated to the head of the benefit unit (BU) and does not necessarily constitute part of their individual income' (Gray 2007: 3).

${ }^{9}$ For FRS details, see the documents accompanying Department for Work and Pensions, National Centre for Social Research and Office for National Statistics Social and Vital Statistics Division (2014). For HBAI subfiles details, see the documents accompanying Department for Work and Pensions (2013).

${ }^{10}$ We do not make any change to children's incomes as careful examination revealed that children's incomes are identical in the FRS and HBAI data.
} 
are fully consistent with the HBAI family and household income data. ${ }^{11}$

Once we have obtained our HBAI individual-income series, the HBAI-SPI individual income series is derived from it. For all individuals in families not subject to the SPI adjustments we set individual gross and market incomes equal to the corresponding HBAI values for years before 2005/06.

For individuals in a family subject to the SPI adjustment, we start from the raw FRS individual gross and market income series rather than the HBAI series. This is because the HBAI-SPI individual income series available from 2005/06 onwards reveal that members of couples who are not subject to the SPI adjustment themselves but who belong to an SPIadjusted family, are assigned their FRS income rather than their HBAI income. We calculate the income change associated with the SPI adjustment as the difference between HBAI-SPI and FRS incomes at the family level for gross and market incomes respectively. We then identify individuals subject to the SPI adjustments and add the income change to their individual income. Before 1997/98 this is straightforward because individuals subject to the SPI adjustment within each family are explicitly identified in the HBAI subfiles. For 1997/98 onwards, we know only the number of individuals within each family subject to the SPI adjustment, and whether these individuals are pensioners or non-pensioners. If this is insufficient information to uniquely identify the individual subject to the SPI adjustment, we assume it is the individual with the largest FRS individual gross income who is subject to the SPI adjustment. In the few cases where both members of a couple are subject to the SPI adjustment, we assume equal sharing of the SPI adjustment. We ignore the post-SPI adjustment modifications made to individual incomes by DWP statisticians.

When we compare our derived variables and the actual SPI-adjusted variables, an exercise possible for 2005/06 and later years, we find that our approach allows us to accurately identify the individuals subject to the SPI adjustment with very few exceptions, and our methods yield a very close approximation to the actual SPI-adjusted variables. For the 1,105 individuals subject to SPI adjustments between 2005/06 and 2012/13, and the 939 partners of these individuals, the average difference between our derived gross income variables and their HBAI-SPI counterpart is $£ 0.01$ per week. The difference is greater than $£ 4$ in 66 cases only. In addition, we obtain almost exactly the same mean and median for gross

\footnotetext{
${ }^{11}$ Although our assumption that income-shares of individuals within families are unaffected by HBAI adjustments is often violated, the deviations from this assumption only have minor effects in the sense that, for years when they can be compared, our SPI-adjusted income variables are very close to those created by the DWP (see below).
} 
and market incomes (Appendix Figure C1). ${ }^{12}$

The DWP does not make individual-level net income variables available in the publicuse files and we are unable to derive them. There is no publicly-accessible tax-benefit microsimulation model like the DWP's that could do the requisite calculations for each year over the period we consider.

\subsection{Our HBAI-SPI2 adjustment}

Estimates of top income shares derived from HBAI-SPI data do not match the corresponding top income shares estimated by WTID from tax data, as we show below. This motivates our 'SPI2' adjustment to improve the top income coverage of the HBAI data.

In terms of the DWP's goals for the SPI adjustment of improving the quality of data on top incomes and combatting spurious volatility (see the Introduction), our strategy focuses on the first aim though with a different reference point (WTID estimates of top income shares rather than SPI ones). However, as we show below, our approach also reduces year-to-year volatility in estimates.

We derive our HBAI-SPI2 income variables for each fiscal year as follows. First, we rank individuals in the SPI unit record data by their pre-tax income. Second, we allocate individuals to income groups, with the size of each group equal to $1 / 1000^{\text {th }}$ of the total adult population shown by the WTID control total for the relevant year. Third, we calculate the average income for each income group. Next, we repeat the first and second steps with the HBAI data for the same year using our derived measure of (pre-SPI adjustment) HBAI individual gross income and the FRS grossing-up weights. ${ }^{13}$ Finally, for each of the 100 top HBAI income groups (i.e. the top 10 per cent), we replace the individual-level HBAI incomes with the mean income of the corresponding group in the SPI.

This method ensures that total pre-tax (gross) income for the top 10 per cent - and for the 100 centile groups of the top $10 \%$ - is the same in the HBAI and in the SPI/WTID data. We also apply the same approach to derive SPI2-adjusted market income variables using group mean incomes from the SPI. ${ }^{14}$

\footnotetext{
${ }^{12}$ Our consistently estimated individual HBAI-SPI variables are available upon request.

${ }^{13}$ In additional work (available from the authors), we re-estimated our inequality estimates using the HBAI-SPI grossing-up weights instead of the FRS ones. It has virtually no effect on our results, because the differences in the weights are small.

${ }^{14}$ This may not lead to a perfect match in the top 10 per cent total market income in the HBAI and in the SPI to the extent that SPI members of the top 10 per cent may differ depending on whether the ranking is based on gross or market income. In practice, however, the difference is likely to be minimal.
} 
Our use of 1,000 income groups and 100 SPI cell-means for imputation is a choice that reflects the balance of multiple considerations. For example, 1,000 is the minimum number of income groups required to replicate total SPI income for each $0.1 \%$ of the population. The more income groups we use, the better will the adjusted survey data be able to account for income differences within the richest groups in the SPI. However, there are far fewer individuals in the HBAI than in the SPI data. This means that HBAI individual grossing-up weights are relatively large (typically between 500 and 1,500), which imposes a limit to the number of income groups we can construct. There is also a limit to how far down the income distribution it is desirable to go for the implementation of this alternative SPI adjustment. The lower the individual income, the more important that non-taxable income is and this is likely to be better captured by the survey than by the tax data. There is a further practical reason why we stop at the top 10\%: this is the largest top income group considered by the top incomes literature (and the WTID). ${ }^{15}$

Because the same SPI unit record data underlie both our HBAI-based data imputations and the WTID estimates, we ensure consistency in the total income of individuals in the top $10 \%$ of the distribution. Hence we will obtain the same top income shares from the two sources provided we use the same income and population control totals. For gross income, we can use either the income control total from the WTID or the internal HBAI control total (i.e. the weighted sum of individual incomes) and assess the difference it makes. However, when considering different income definitions - for instance, market income - we cannot use the WTID, which does not contain suitable income control totals for the UK. We therefore use internal HBAI control totals for these other income definitions.

By using the WTID estimates of the total adult population, we ensure that the number of individuals in the top 1 per cent is the same in the HBAI and in the WTID. However, WTID population controls are not available for alternative definitions of the incomereceiving unit such as the family or the household. Instead, we rely on the internal HBAI population control totals (the sum of the relevant grossing-up weights in each year). This approach slightly underestimates the size of the top income groups, and thus the top income shares, since between 1\% (in recent years) and 6\% (in early years) of the full UK adult population is not represented in the HBAI. This is because the FRS excludes homeless and institutionalized people as well as households containing a married adult whose spouse is

\footnotetext{
${ }^{15}$ In additional work (available from the authors), we have imputed SPI cell-means to only the top $1 / 2 \%$ of survey incomes rather than the top $10 \%$. (The former fraction roughly corresponds to the proportion of individuals with SPI-adjusted incomes.) Our qualitative results about inequality trends in this case are much the same as those reported below.
} 
temporarily absent and, before 2002/03, individuals living in Northern Ireland.

\section{How well do survey-based estimates of top income shares match those from the WTID?}

By means of our cross-walk of income and income-sharing unit definitions, from standard HBAI ones to those corresponding to the ones used in the WTID (individual-level gross income for individuals aged 15 years or more), we are now able to compare like with like. In this section, we analyse how well the various survey data estimates of top income shares match those provided by the WTID.

The first comparison is summarized in Figure 2, which shows estimates for the income shares of the top 1\% for 1995/96 through 2010/11 derived using multiple data sources and definitions. ${ }^{16}$ The notes to the figure provide a key to the series acronyms used here and in later figures and tables.

The benchmark reference point in Figure 2 is the WTID series, the uppermost one. According to this, the top 1\%'s share increases from around 11\% in 1995/96 to 13.5\% in $2000 / 01$, is slightly smaller over the next four years, before increasing to around $15.5 \%$ in 2007/08.

There is a sharp fall in the top 1\% share between 2009/10 and 2010/11. The Great Recession and its aftermath provide one obvious explanation but this conclusion must be treated with caution. A 50\% top marginal rate of income tax was introduced in April 2010 (up from 40\%), and the announcement and introduction of this tax rate provided incentives for high income tax payers to bring forward income to 2009/10 that would otherwise have been reported in 2010/11 income tax returns or possibly later years. This is the process of 'forestalling', discussed in more detail by HM Revenue and Customs (2012) and Cribb et al. (2012, 2013). This, and the unavailability of SPI data for 2008/09, make assessments of recent trends in the UK income distribution problematic for any measure calculated using data on top incomes, especially top income share statistics. We therefore focus our discussion on the estimates through to $2007 / 08$.

[Figure 2 near here]

\footnotetext{
${ }^{16}$ Our discussion here and later discusses point estimates of statistics; the focus is assessing differences associated with changing definitions and sources (non-sampling variation) rather than assessing the impact of sampling variability. However, for reference, we provide estimates of standard errors for all our inequality measures in Appendices F and G.
} 
The series shown in grey in Figure 2 refer to estimates based on the FRS and HBAI data, i.e. without SPI adjustments. These provide broadly similar estimates of levels and trends to each other, but compared to WTID series, the estimates are not only substantially lower in corresponding years but also fluctuate substantially from year to year. This is the 'spurious volatility’ that the HBAI’s producers aimed to offset by introducing the SPI adjustment.

The SPI adjustment is indeed successful in this respect: the HBAI-SPI series is much smoother than the two non- adjusted series and, in addition, the HBAI-SPI estimates are generally larger in each year as well. However, these estimates are distinctly smaller than the corresponding WTID ones. The differences range between around $1 \frac{1}{2} 2$ and 3 percentage points, with the larger differences more apparent in the mid- to late-2000s. For example, the WTID estimate of the top $1 \%$ share for $2007 / 08$ is $15 \frac{1}{2} \%$ compared to the HBAI-SPI estimate of $12 \frac{1}{2} 2$ percent, i.e. around one-fifth smaller, which is a relatively large difference. Put differently, we provide UK evidence to support Atkinson, Piketty, and Saez’s (2011) finding for the USA that household survey estimates do not fully capture the rise in inequality shown by tax data (see the Introduction).

Do our HBAI-SPI2 estimates of the share of the top 1\% do better? Look at Figure 3 which shows the WTID and HBAI-SPI series (as in Figure 2) plus two HBAI-SPI2 series. The first uses the WTID population and income controls, and SPI-derived values for the top $10 \%$ of individuals in the HBAI as discussed in Section 2. This is the series labelled 'HBAISPI2 individual gross income (WTID controls)'. The second series uses the same SPI values for the top $10 \%$ of individuals in the HBAI (the same numerator), but uses HBAI-estimated population-weighted total gross income in the denominator. The HBAI-SPI2 series with WTID controls is virtually identical to the WTID series (by construction). The HBAI-SPI2 series using HBAI population weights does less well but does much better than the HBAI-SPI series: it is much closer in levels and trends to the WTID series. Put differently, the use of the internal HBAI control totals rather than the WTID ones leads to an under-estimation of the income share of the top $1 \%$ by around one percentage point, but the trends are similar. ${ }^{17}$

[Figure 3 near here]

\footnotetext{
${ }^{17}$ For more information about differences between WTID and internal HBAI control totals, see Appendix D. Figure D1 summarizes differences in denominators, and shows that the increasing gap between WTID and HBAI-SPI2 total income between 2001/02 and 2004/05 largely explains the increasing gap over this period between top 1\% income shares based on WTID and HBAI control totals. In contrast, differences in population control totals in the WTID and HBAI adult populations do not appear to play an important role in explaining differences in top income shares (Figure D2).
} 
The close match between estimates based on HBAI-SPI2 data with WTID controls and the WTID estimates is also found if we examine different top income share statistics. See Appendix Figures E1 and E2 for comparisons of series for the top $0.1 \%$, top $10 \%$ to top 5\%, and top $5 \%$ to top $1 \%$ income groups.

We have demonstrated that our HBAI-SPI2 data are able to almost exactly capture WTID levels and trends based on the SPI unit record data when we use WTID population controls and it does a reasonable job of doing so even when we use internal HBAI population totals. It is the latter that we use in the next two sections for the reasons given earlier.

\section{Using our combined (HBAI-SPI2) data for better cross-national comparisons of top incomes in the UK and USA}

The top incomes literature employs only tax record data and is therefore limited to looking at distributions of taxable income among tax units. Because the definitions of the tax unit and taxable income differ across countries, there are potential comparability problems for crossnational comparisons of top income shares. By exploiting the flexibility of household survey data and using cross-walked definitions, we can address this issue.

We illustrate this lesson with the UK-US comparison summarized in Figure 4. The first top $1 \%$ income share series is taken from the WTID estimates for the USA, based on the estimates of Piketty and Saez $(2003,2008)$ and subsequent updates. Reflecting US personal tax administration, the WTID estimates refer to taxable market income and the incomesharing unit is the family. We focus on the US top income series that exclude taxable realized capital gains, since realized capital gains are not included in the UK series. ${ }^{18}$

Figure 4 shows that the share of market income held by the top 1\% of US families the series labelled 'US family market income' - increased from around 13.5\% in 1995 to around $16.5 \%$ in 2000 before falling over the recession years of the early-2000s. The share then reached a peak of just over 18\% in 2007, just before the Great Recession hit the USA. Shares then declined over the next two years but started to recover in 2010/11.

[Figure 4 near here]

In the top incomes literature, these US estimates of levels and trends are often compared with the WTID estimates for the UK discussed earlier: see the substantial review

\footnotetext{
${ }^{18}$ See Armour, Burkhauser, and Larrimore (2013, 2014) for discussions of the relative merits of including or excluding taxable realized capital gains in measures of income.
} 
articles by Atkinson, Piketty and Saez (2011) as well as Roine and Waldenström (2015), for example. This UK series refers to gross income and the sharing unit is the individual adult. According to the WTID series, top 1\% income shares are substantially lower in the UK than in the USA, but follow approximately the same trend though 2007.

When we cross-walk our UK survey data from a gross income definition to a market income definition (moving from the series labelled 'individual gross income' to the one labelled 'individual market income'), the estimated top 1\% share increases by around 2 percentage points each year, a relatively large change. ${ }^{19}$ On the other hand, if we shift to the family but retain the gross income definition, estimated top $1 \%$ shares fall by about 1 percentage point or slightly more: look at the 'family gross income' series.

The UK definition that is most comparable with the US one is the distribution of market income among families (the 'family market income' series). Figure 4 shows that the net result of using this series rather than the 'individual gross income' one is only a relatively small increase in the share of income held by the top $1 \%$. The reason is that the two definitional changes not only go in opposite directions but almost completely offset each other.

This robustness in the cross-national comparison is not necessarily the general rule. See the series for the top $0.1 \%$, top $5 \%$ to $1 \%$, and top $10 \%$ to $5 \%$ shares presented in Figures 5 to 7 in the same format as Figure 4. The further up the distribution the shares refer to, the more important is the shift from an individual to a family definition of the tax unit and the less important is the shift from gross to market income (at the very highest top income ranges almost all income is market income). When we focus on the top $0.1 \%$, our ' $U K$ family gross income' estimates are smaller than the 'UK individual gross income' estimates (Figure 5). At the lower top income ranges not only are the estimates from the 'UK family market income' series greater than the 'UK individual gross income' estimates, they are greater than the corresponding estimates for the USA (Figures 6 and 7).

[Figures 5-7 near here]

The other series shown in Figures 4 to 7 allow us to examine what happens to top income shares if definitions are employed that are the norm in income distribution analysis based on household survey data. It has long been argued that the appropriate income-sharing unit is the household, that nominal incomes should be adjusted to account for differences in household size and composition using an equivalence scale, and that distributional statistics

\footnotetext{
${ }^{19}$ The UK estimate is slightly larger than its US counterpart in 2009/10 but we give little weight to this finding because of the forestalling problem discussed earlier.
} 
relate to all individuals in the population. Burtless (2015) criticizes the definitions used in the top incomes literature on these grounds. More generally, see the case for the conventional survey definitions made by, inter alia, Gottschalk and Smeeding (1997), d'Ercole and Förster (2012), and the influential Canberra Group (2011).

Our 'UK household gross income' and 'UK equivalised household gross income' series show that once these factors are taken into consideration the share of income held by the top $1 \%$ of individuals is substantially reduced relative to the ' $\mathrm{UK}$ individual gross income' series which employs the definitions used in the top incomes literature. This finding is unsurprising since households are institutions that enable individuals to pool and share income, and larger households benefit from economies of scale relative to smaller-sized ones.

Although estimates of top income share levels are sensitive to the choice of definition of income and income sharing-unit, Figures 4 to 7 shows that estimates of trends are similar. All of the UK series move closely in parallel with each other. This finding echoes that of Lakner (2014) who showed that US top income share trends were similar when various adjustments were made for tax unit size.

\section{Using our combined (HBAI-SPI2) data to summarize inequality differently}

The very nature of tax return data means that inequality is summarized using top income share estimates, and the shares refer to incomes above the $90^{\text {th }}$ percentile. By contrast, most of the survey-based income distribution literature summarizes inequality using indices such as the Gini coefficient that take account of income differences throughout the full income range. A further advantage of our survey-based approach is that we can calculate these measures in addition to top income shares, and see the extent to which they move in tandem with top income shares. ${ }^{20}$

In Figure 8 we compare Gini coefficient estimates based on HBAI-SPI and HBAISPI2 data, and for both gross and market income definitions. The sharing unit is the household throughout, and estimates refer to all individuals (including those aged less than 15). The figure shows unsurprisingly that market income is more unequally distributed than

\footnotetext{
20 This is relatively unexplored territory. Leigh (2007) examined the association between movements in top income shares and Gini coefficients using a country panel data set for 13 rich countries, finding a positive but far from perfect correlation between the two measures. Our country case study approach allows us to examine in more detail (for the UK) when and how trends differ for the two measures and, moreover, the sources of any divergence in trends.
} 
gross income (the latter includes redistributive government transfers), regardless of which series is employed. Also unsurprising is that the Gini coefficients are larger for the HBAISPI2 series than for the HBAI-SPI in corresponding years, since the HBAI-SPI2 data capture top incomes better.

What is also of particular interest is the more marked increase in the Gini coefficient between 2004/05 and 2007/08 - reflecting better capture of the rise in top income shares over this period. The bottom series, in grey, is the HBAI-SPI series for household net income. This corresponds to the series reported in the official HBAI statistics (see also Figure 1). ${ }^{21}$ These Gini estimates are some 4 to 5 percentage points lower than their gross income counterparts but the trends are similar.

[Figure 8 near here]

Table 2 extends our comparisons of the HBAI-SPI2 and HBAI-SPI data by comparing the growth in equivalised household gross income at different points in the income distribution, from the bottom to the top. Unsurprisingly, there is very little difference between datasets in estimated income growth for the bottom $90 \%$ of the distribution since the adjustments incorporated to both series focus on the richest individuals. However, the HBAISPI2 data show higher income growth than the HBAI-SPI for individuals between the $91^{\text {st }}$ and $95^{\text {th }}$ percentiles and those between the $96^{\text {th }}$ and $99^{\text {th }}$ percentiles, and substantially greater income growth for the top $1 \%$ (102\% versus $76 \%)$. Interestingly, there is virtually no difference in estimates of the change in the median across the datasets. Differences are slightly more pronounced for the mean (35\% versus 31\%) and they appear to be driven by a divergence in income growth in the final subperiod (4\% versus 6\% between 2004/05 and 2007/08).

[Table 2 here]

We now expand the comparisons between data sets by looking at additional inequality indices. In addition to the Gini coefficient, we consider the mean logarithmic deviation (MLD), the Theil index, and half the squared coefficient of variation. These are members of the generalized entropy family of indices, with sensitivity parameters 0,1 , and 2 respectively. The larger the parameter, the more sensitive is the index to income differences at the top of the distribution relative to those in the middle or at the bottom (the Gini coefficient and MLD are middle-sensitive indices). Table 3 shows inequality levels for four years between 1995/96 and 2007/08 and changes over periods between those years. Again, the distributions refer to

\footnotetext{
${ }^{21}$ Recall that we cannot derive individual net income variables: see section 2.4.
} 
equivalised household income among all individuals, with gross income series for HBAISPI2 and HBAI-SPI, and a net income series for the latter only. Period-specific changes are quite similar for HBAI-SPI gross and net definitions; the main contrast is between the differently-adjusted gross income series. The exception is the period 1995/96 to 2001/02 when, for each index, all income definitions show similar inequality increases.

The Gini coefficient for the HBAI-SPI2 data is greater than the HBAI-SPI data for both $1995 / 96$ and $2007 / 08$, as is the percentage change between those two years (10\% versus $7 \%)$. Moving to the other three indices, we see again that the level of inequality is greater in the HBAI-SPI2 data. However, the more top-sensitive is the index (as we move down the panels in the table), the larger is the measured increase in inequality. For example, the increase between 1995/96 and 2007/08 in half the coefficient of variation squared according to the HBAI-SPI2 data is much larger than the increase according to the HBAI-SPI data (140\% versus 50\%). We know from the WTID estimates that the concentration of incomes at the very top increased substantially over the period as a whole according to the top income shares (cf. Figure 1 and 3), and the more comprehensive top-sensitive indices are also picking this up. (The subperiod changes - inequality rise, fall, and rise again - are also similar.) In short, the more that the survey data are adjusted to better capture top incomes, the greater is the effect on inequality that is observed.

[Table 3 near here]

\section{Summary and Conclusions}

Exploiting the flexibility provided by access to unit record household survey data, notably the ability to cross-walk between different sets of definitions so that like is compared with like, we have provided the most extensive comparison of UK inequality estimates derived from survey and income tax data. In addition, we have shown how, with reconciled definitions, the two data sources can be combined to yield better estimates of UK inequality levels and trends. We have also examined the consequences of using inequality indices that account for income differences throughout the income range, unlike top income share measures.

Our results, based on the reconciled and combined data, highlight that the magnitude of the estimated increase in inequality, especially between 2004/05 and 2007/08, depends on whether the index is middle- or top-sensitive. Nonetheless, all inequality indices show a greater increase in inequality over the period than do the estimates reported in the official 
income distribution statistics.

The flexibility of unit record survey data also allows us to employ different definitions of income and the income-sharing unit. We have shown how we can improve the comparability of cross-national comparisons. With UK definitions cross-walked to the definitions underlying the US top income share series, we have shown that conclusions about transatlantic differences in top income shares depend on which top income group one looks at.

More generally, we have shown that it is possible to adjust household survey data to take better account of their non-coverage of top incomes, as long as one has access to tax return data for top income groups. ${ }^{22}$ The official income distribution statistics in the UK have long exploited this possibility using their SPI adjustment, and we have shown with our SPI2 adjustment that it is possible to take even greater account of top incomes.

One advantage of our data combination approach relative to the DWP's is that we exploit the well-known WTID estimates based on tax return data to provide a benchmark. The accuracy of this benchmark is conditional on the reliability of the estimates of the population and income control totals that the WTID employs. Assessment of these would be a valuable topic for further research, with pay-offs for the top incomes literature as well as for survey-based approaches like ours.

A second advantage of our approach is that it is simpler than the DWP's. It does not use group-specific cell-means to do the 'SPI adjustment', no stratification groups need be defined, and there is no need for any SPI-based projections as currently employed. Given our interest in improving inequality estimates, we seek better coverage of high incomes regardless of who has them. Individuals with the top incomes in some stratification groups are not in the top income group for the population as a whole.

Arguably the DWP's current SPI adjustment is fit for purpose, because the principal focus of its official HBAI reports is the prevalence of low income with assessments based on low income cut-offs equal to fractions of median income (not fractions of mean income). Estimates of median-based cut-offs and of low income prevalence are likely to be insensitive to variations in the nature of SPI adjustment employed, ours included.

The problem with this argument is that it fails to recognise that the DWP's HBAI

\footnotetext{
${ }^{22}$ An alternative approach is to calculate summary inequality measures separately for the very rich using tax data and for the rest of the population using survey data and then combine the summary measures (rather than, as here, combining the data and calculating the inequality measure from these). See e.g. Atkinson (2007), Alvaredo (2011), and Jenkins (2015). Of course, this approach also requires like for like definitions in both sources.
} 
survey-based data are also the most commonly-used source for assessing inequality in the UK. Survey data are also employed in most other countries for the same purpose, and for cross-national comparisons. But household surveys in all countries are subject to undercoverage of top incomes. We therefore hope that our reconciled and combined data approach will stimulate further research on how to take better account of top incomes in inequality assessments.

\section{References}

Alvaredo, F. (2011). A note on the relationship between top income shares and the Gini coefficient. Economic Letters, 110 (3), 274-277.

Alvaredo, F., Atkinson, A. B., Piketty, T., and Saez, E. (2013). The top 1 percent in international and historical perspective. Journal of Economic Perspectives, 27 (3), 320.

Alvaredo, F., Atkinson, A. B., Piketty, T., Saez, E. (2015). The World Top Incomes Database. http://g-mond.parisschoolofeconomics.eu/topincomes/. Accessed Day Month Year.

Armour, P., Burkhauser, R. V. and Larrimore, J. (2013). Deconstructing income and income inequality measures: a crosswalk from market income to comprehensive income. American Economic Review, 101 (3), 173-177.

Armour, P., Burkhauser, R. V., and Larrimore, J. (2014). Levels and trends in United States income and its distribution: a crosswalk from market income towards a comprehensive Haig-Simons income measure. Southern Economic Journal, 14 (2), 271-293.

Atkinson, A. B. (2005). Top incomes in the UK over the twentieth century. Journal of the Royal Statistical Society, Series A, 168 (2), 325-343.

Atkinson, A. B. (2007). Measuring top incomes: methodological issues. In: A. B. Atkinson and T. Piketty, (eds), Top Incomes over the Twentieth Century: A Contrast Between Continental European and English-Speaking Countries. Oxford: Oxford University Press.

Atkinson, A. B. (2012). UK estimates of top income shares 2009-2010: Revised note on methods, World Top Incomes Database Methodological Notes, 12 April 2012.

Atkinson, A. B. (2015). Inequality. What Can Be Done? Cambridge, MA: Harvard University Press. 
Atkinson, A. B. and Brandolini, A. (2001). Promises and pitfalls in the use of secondary data sets: income inequality in OECD countries as a case study. Journal of Economic Literature 39 (3), 771-799.

Atkinson, A. B. and Ooms, T. (2015). UK estimates of top income shares 2012/2013: Note on methods, World Top Incomes Database Methodological Notes, 25 March 2015.

Atkinson, A. B., and Piketty, T. (eds). (2007). Top Incomes over the Twentieth Century: A Contrast Between Continental European and English-Speaking Countries. Oxford: Oxford University Press.

Atkinson, A. B., Piketty, T., and Saez, E. (2011). Top incomes in the long run of history. Journal of Economic Literature, 49 (1), 3-71.

Belfield, C., Cribb, J., Hood, A., and Joyce, R. (2015). Living Standards, Poverty and Inequality in the UK: 2015. Report 107. London: Institute for Fiscal Studies. http://www.ifs.org.uk/publications/7878

Brewer, M., Sibieta, L., and Wren-Lewis. S. (2007). Racing Away? Income Inequality and the Evolution of High Incomes. Briefing Note 76. London: Institute for Fiscal Studies. http://www.ifs.org.uk/bns/bn76.pdf

Burtless, G. (2015). Review of Thomas Piketty's Capital in the Twenty-First Century. Journal of Policy Analysis and Management, 34 (3), 719-727.

Canberra Group (2011). Handbook on Household Income Statistics, second edition. Geneva: United Nations Economic Commission for Europe.

Cribb, J., Joyce, R., and Phillips, D. (2012). Living Standards, Poverty and Inequality in the UK: 2012. Commentary C214. London: Institute for Fiscal Studies. http://www.ifs.org.uk/comms/comm124.pdf

Cribb, J., Hood, A., Joyce, R., and Phillips, D. (2013). Living Standards, Poverty and Inequality in the UK: 2013. Report R81. London: Institute for Fiscal Studies. http://www.ifs.org.uk/comms/r81.pdf

d'Ercole, M. M., and Förster, M. (2012). The OECD approach to measuring income distribution and poverty: strengths, limits and statistical issues. In: D. J. Besharov and K. A. Couch (eds.), European Measures of Income and Poverty: Lessons for the U.S. New York: Oxford University Press, 27-58.

Department of Social Security (1996). Households Below Average Income. Methodological Review. Report of a Working Group. London: Department of Social Security. 
Department for Work and Pensions (2010). Households Below Average Income An Analysis of the Income Distribution 1994/95 - 2008/09. London: Department for Work and Pensions.

Department for Work and Pensions (2013), Households Below Average Income, 1994/952012/13 [computer file]. 7th Edition. Colchester, Essex: UK Data Archive [distributor], October 2013. SN: 5828.

Department for Work and Pensions (2014). Households Below Average Income An Analysis of the Income Distribution 1994/95 - 2012/13. London: Department for Work and Pensions.

Department for Work and Pensions, National Centre for Social Research and Office for National Statistics Social and Vital Statistics Division (2014), Family Resources Survey, 2010-2011 [computer file]. 2nd Edition. Colchester, Essex: UK Data Archive [distributor], October 2014. SN: 7085, http://dx.doi.org/10.5255/UKDA-SN-7085-2 Department for Work and Pensions (2015). Households Below Average Income An Analysis of the Income Distribution 1994/95 - 2013/14. London: Department for Work and Pensions.

Gottschalk, P. and Smeeding, T. M. (1997). Cross-national comparisons of earnings and income inequality. Journal of Economic Literature 35 (2), 633-687.

Gray, C. (2007). SPI documentation - how to decide on thresholds. Unpublished paper. London: Department for Work and Pensions.

HM Revenue and Customs (2012). The Exchequer effect of the 50 per cent additional rate of income tax. London: HMRC.

HM Revenue and Customs KAI Data, Policy and Co-ordination (2014), Survey of Personal Incomes, 2010-2011: Public Use Tape [computer file]. Colchester, Essex: UK Data Archive [distributor], November 2014. SN: 7569, http://dx.doi.org/10.5255/UKDA-SN7569-1.

Jenkins, S. P. (2015). To what extent is inequality increasing? Some data issues. LIS Lecture presented at the $6^{\text {th }}$ ECINEQ conference, Luxembourg, 13 July 2015. http://www.lisdatacenter.org/news-and-events/2015-summer-lecture/

Lakner, C. (2014). Top incomes in the USA, 1960-2005: family size and factor income composition. Chapter 2 of The Determinants of Incomes and Inequality: Evidence from Poor and Rich Countries, DPhil thesis. Oxford: University of Oxford.

Leigh, A. (2007). How closely do top income shares track other measures of inequality? Economic Journal, 117 (524), F619-F633. 
OECD (2008). Growing Unequal? Income Distribution and Poverty in OECD Countries. Paris: OECD Publishing.

OECD (2011). Divided We Stand: Why Inequality Keeps Rising. Paris: OECD Publishing. OECD (2015). In It Together: Why Less Inequality Benefits All. Paris: OECD Publishing. Office for National Statistics (2015). The effects of taxes and benefits on household income, financial year ending 2014. London: Office for National Statistics. http://www.ons.gov.uk/ons/rel/household-income/the-effects-of-taxes-and-benefits-onhousehold-income/2013-2014/index.html

Piketty, T. (2003). Income inequality in France, 1901-1998. Journal of Political Economy 111 (5), 1004-1042.

Piketty, T. (2014). Capital in the Twentieth-First Century. Cambridge, MA, and London: The Belknap Press.

Piketty, T. and Saez, E. (2003). Income inequality in the United States, 1913-1998. Quarterly Journal of Economics 118 (1), 1-39.

Piketty, T. and Saez, E. (2008). Income inequality in the United States, 1913-1998 (tables and figures updated to 2006). http://www.econ.berkeley.edu/ saez/TabFig2006.xls

Roine, J. and Waldenström, D. (2015). Long run trends in the distribution of income and wealth. In: A. B. Atkinson and F. Bourguignon (eds), Handbook of Income Distribution, vol. 2A. Amsterdam: Elsevier-North Holland.

Roser, M. (2015). 'Income inequality: poverty falling faster than ever but the $1 \%$ are racing ahead’, The Guardian, 27 March 2015. http://www.theguardian.com/news/datablog/2015/mar/27/income-inequality-risingfalling-worlds-richest-poorest

Young, T. (2015). Lefty myths about inequality, The Spectator, 4 April 2015. http://new.spectator.co.uk/2015/04/lefty-myths-about-inequality/ 
Figure 1. Trends in UK income inequality since 1961

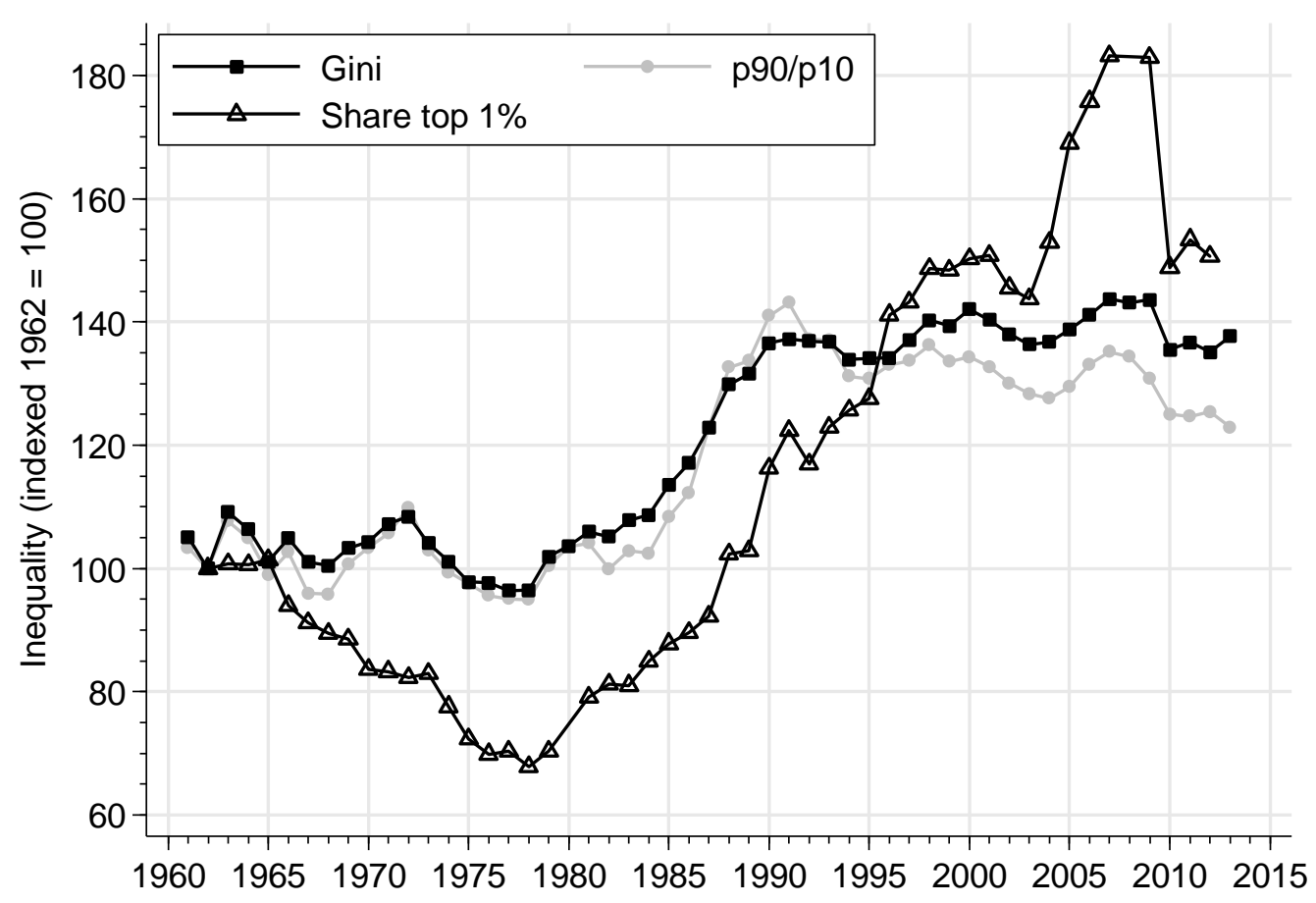

Notes: The Gini and p90/p10 measures are based on household survey data using the same definitions as employed by the UK's official income distribution statistics (source: authors' derivations from the spreadsheet accompanying Belfield et al. 2015). The top 1\% share measure is based on tax return data (source: authors' derivations from Alvaredo et al. 2015). The data sources and income definitions that each series employs are discussed further in Section 2. 
Figure 2. Top 1\% income shares: estimates from survey and tax return data

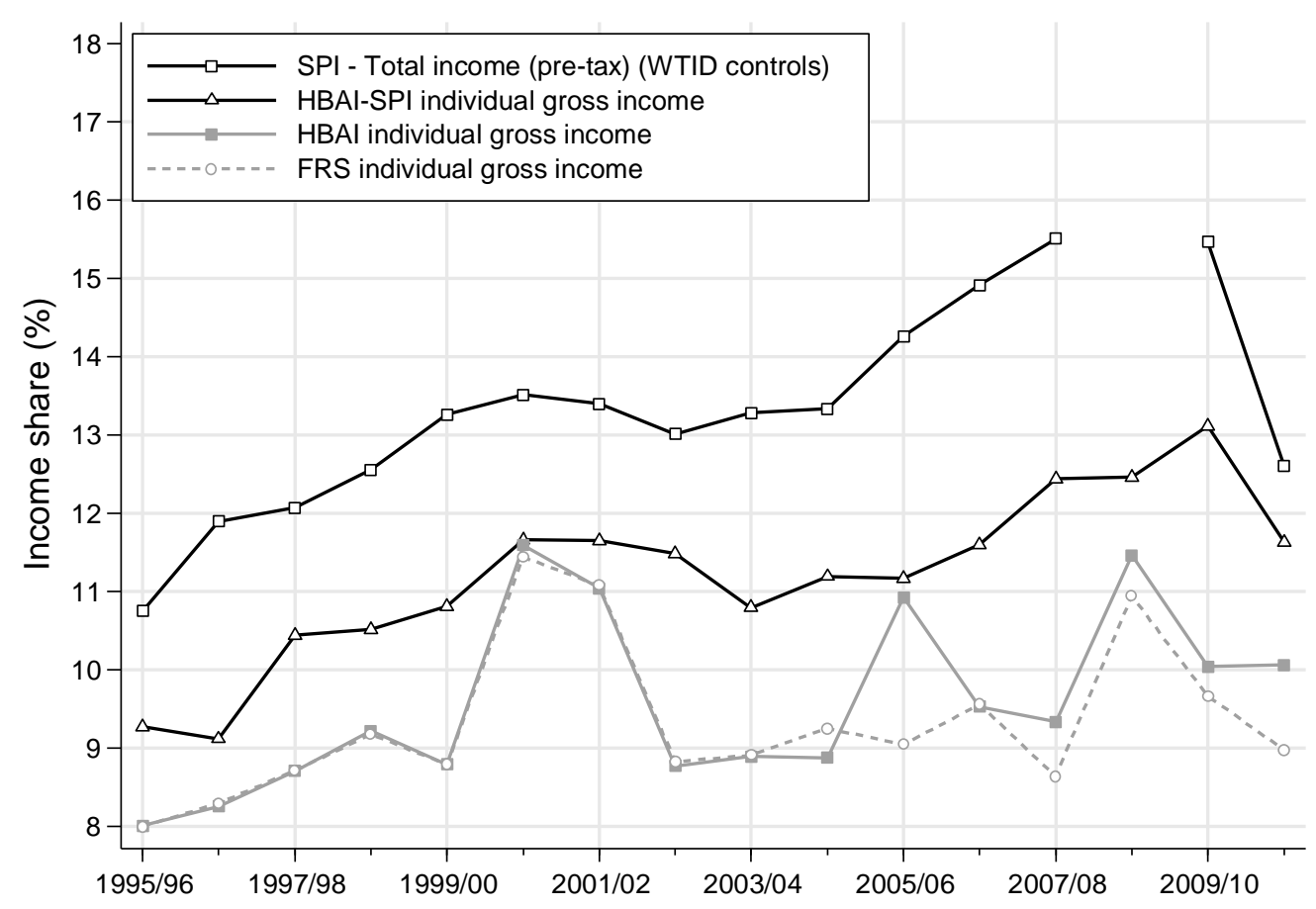

Notes: Northern Ireland is included in the survey-based series only from 2002/03 onwards. The acronyms refer to the following data sources and series:

SPI: the Survey of Personal Incomes (income tax return data)

FRS: Family Resources Survey, basic income variables

HBAI: the DWP's cleaned-up FRS income variables

HBAI-SPI: the HBAI series incorporating the SPI adjustment

WTID: World Top Incomes Database (Alvaredo et al. 2015).

The different series are explained further in Section 2.

Source: Authors' calculations based on FRS, HBAI, SPI and WTID data.

(Stata graph top1b1) 
Figure 3. Top 1\% income shares: estimates from SPI/WTID data and combined survey data

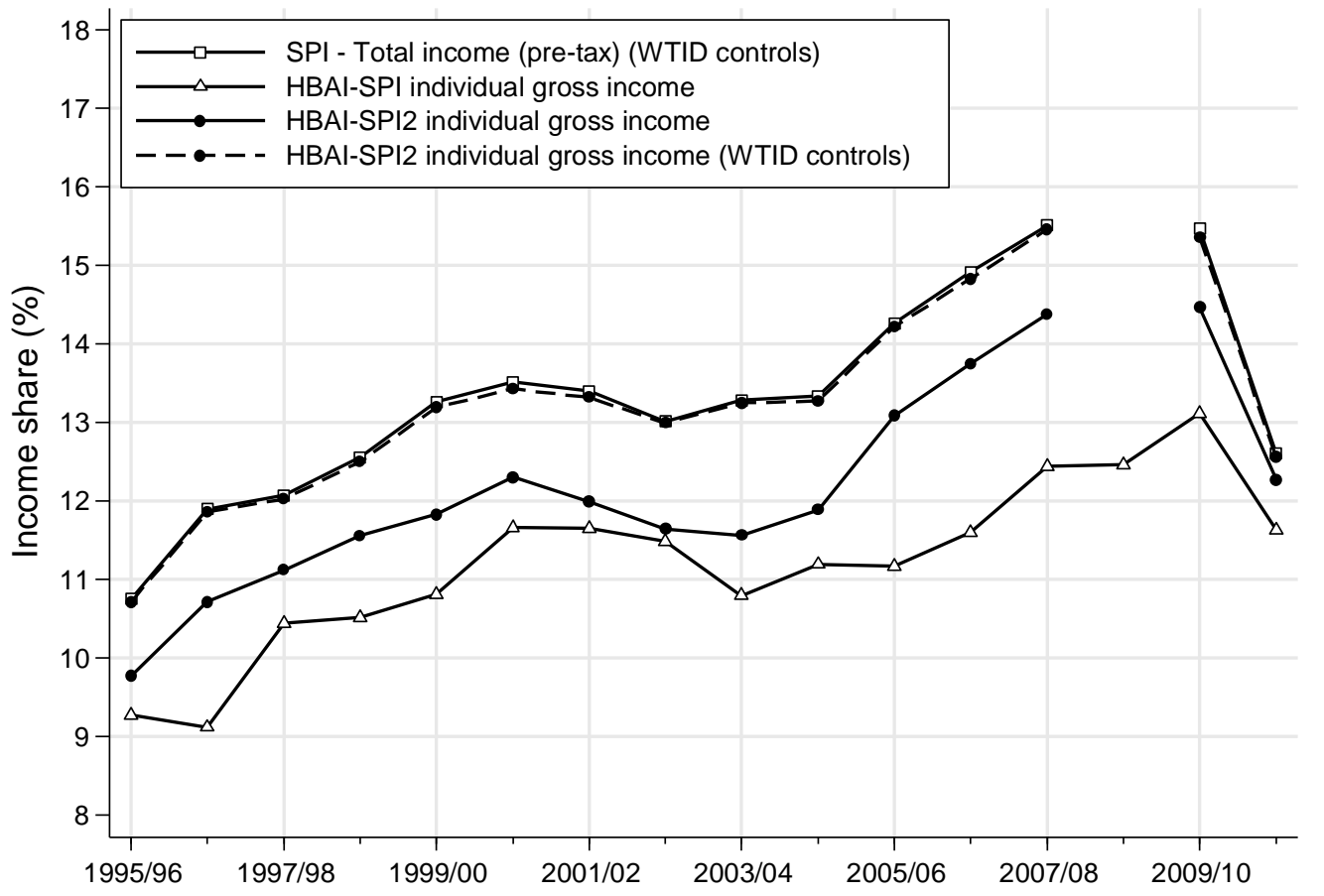

Notes and sources: As for Figure 2.

(Stata graph top1n1) 
Figure 4. Top 1\% income shares in the UK (HBAI-SPI2 series), with alternative units of analysis and income definitions and comparison with the USA

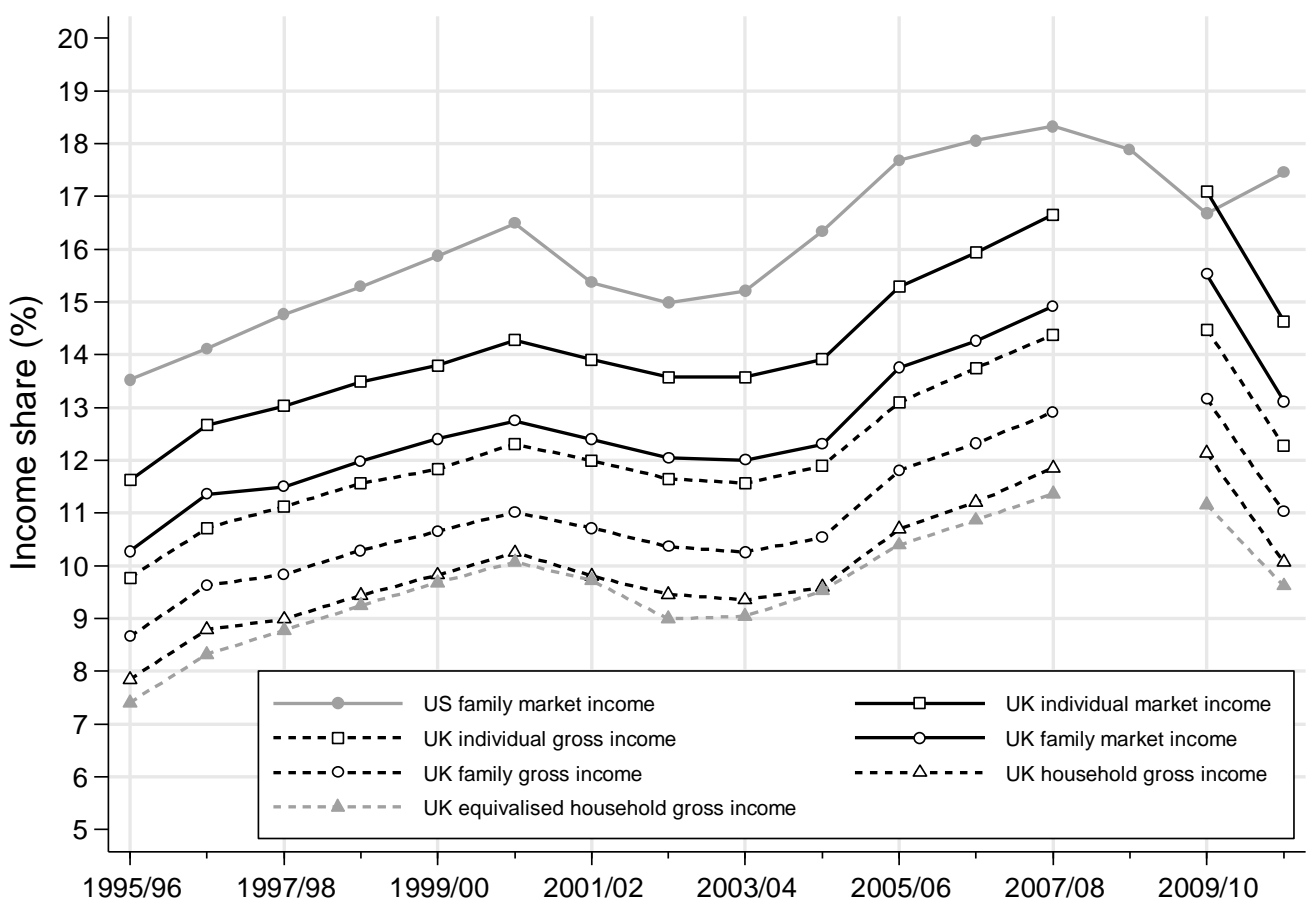

Notes and sources: as for Figure 2.

(Stata graph top1g) 
Figure 5. Top 0.1\% income shares in the UK (HBAI-SPI2 series), with alternative units of analysis and income definitions and comparison with the USA

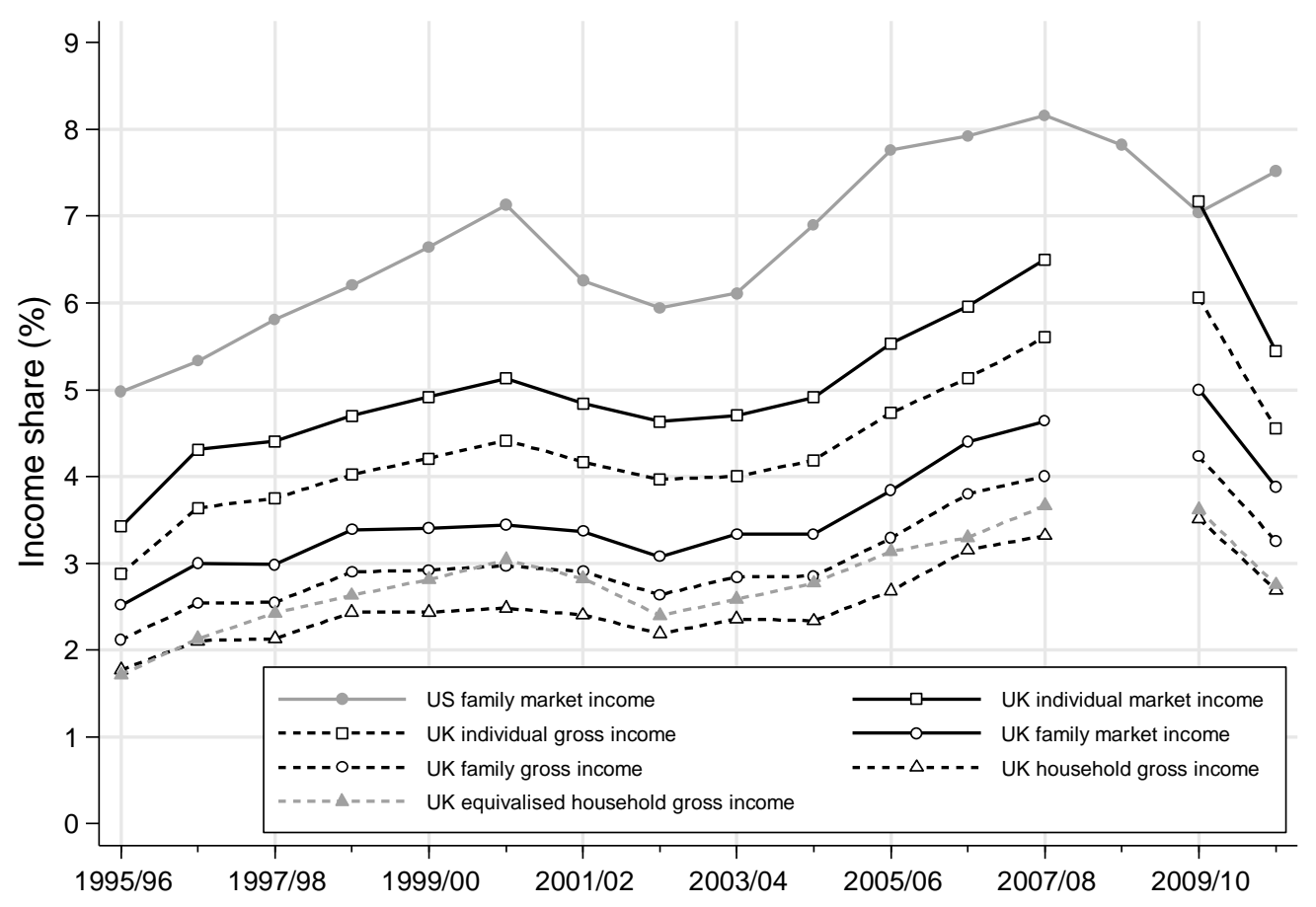

Notes and sources: as for Figure 2.

(Stata graph top01c) 
Figure 6. Top 5\% to $1 \%$ income shares in the UK (HBAI-SPI2 series), with alternative units of analysis and income definitions and comparison with the USA

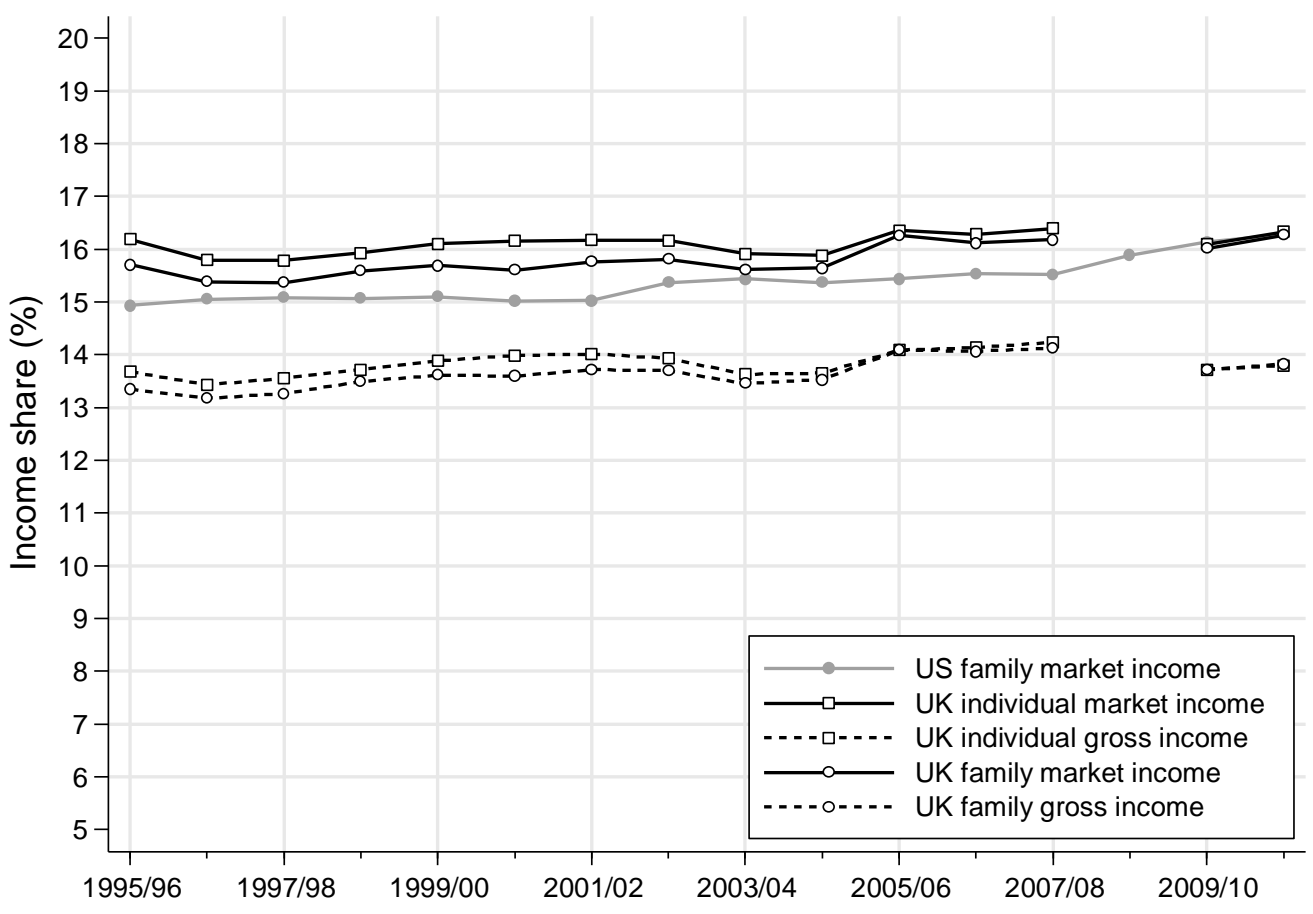

Notes and sources: as for Figure 2.

(Stata graph top5-1b) 
Figure 7. Top $10 \%$ to $5 \%$ income shares in the UK (HBAI-SPI2 series), with alternative units of analysis and income definitions and comparison with the USA

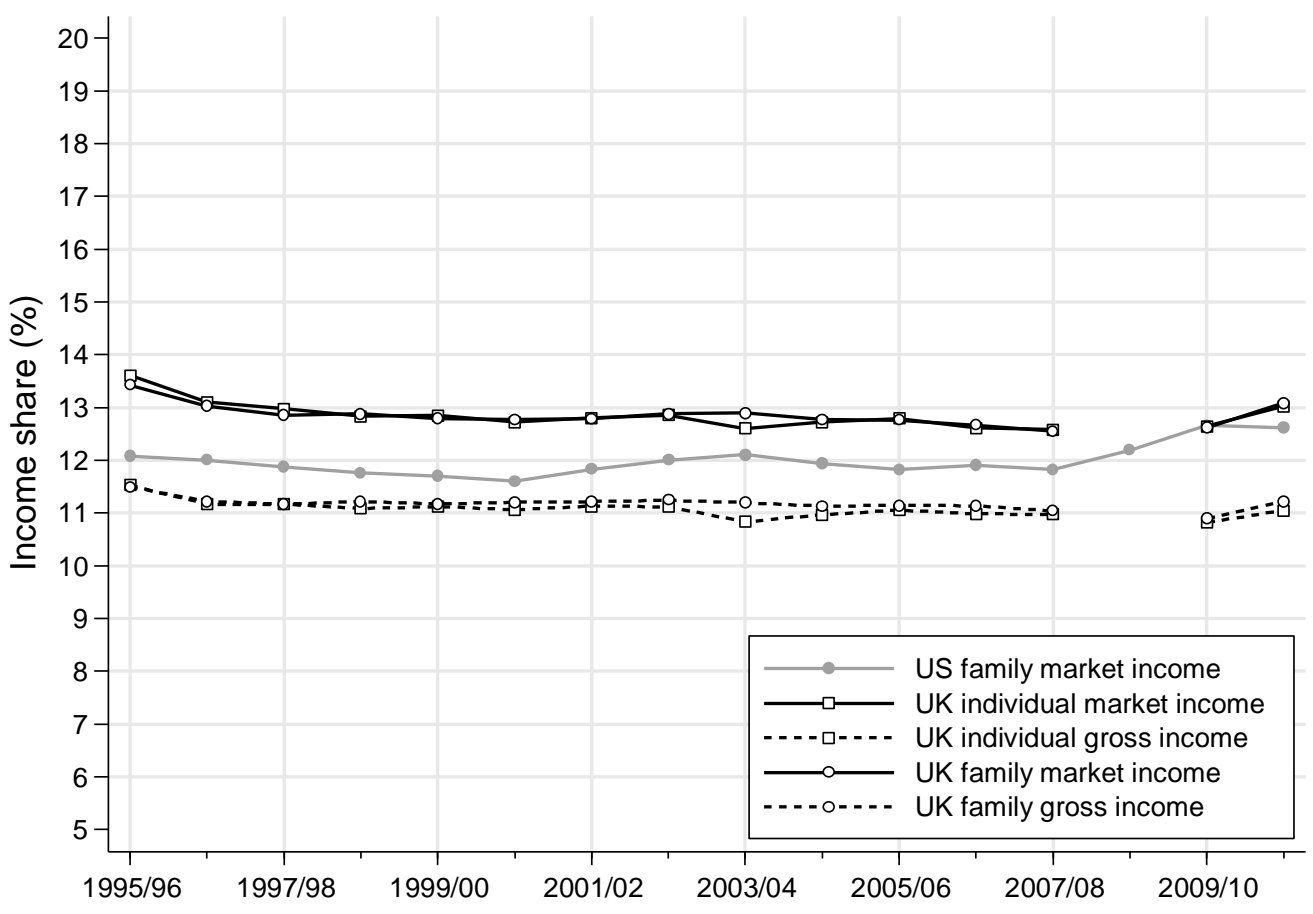

Notes and sources: as for Figure 2.

(Stata graph top10-5b) 
Figure 8. Gini coefficients using different household income definitions: HBAI-SP2 versus HBAI-SPI estimates

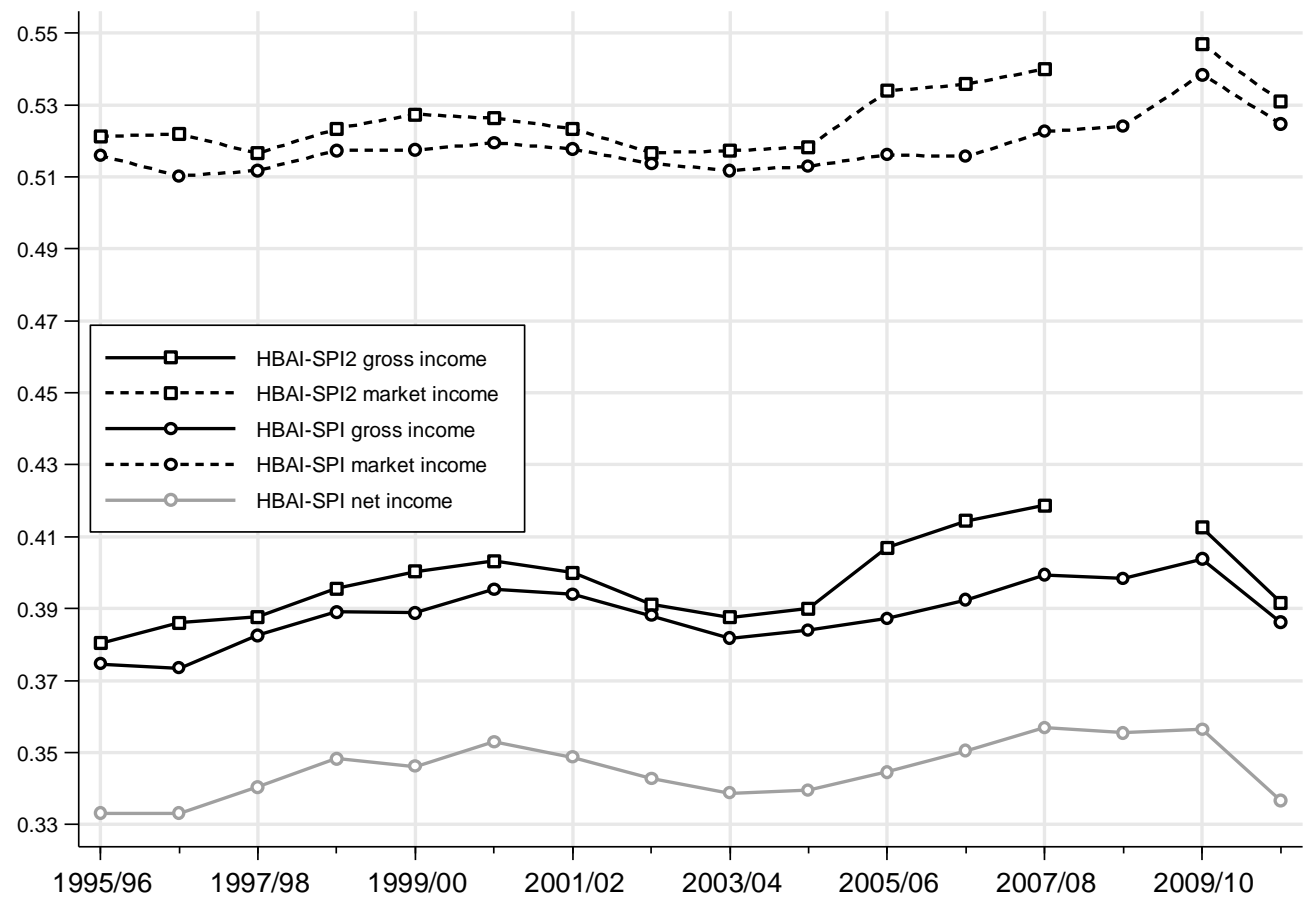

Notes: In each series, household income is equivalised using the modified-OECD scale. The individual is the unit of analysis. Estimates are based on the full population (aged less than 15 as well as aged $15^{+}$).

Sources: as for Figure 2.

(Stata graph Gini1) 
Table 1. Availability of income variables in the FRS and HBAI subfile unit record data, by definition of income and income-sharing unit

\begin{tabular}{|c|c|c|c|c|}
\hline \multirow{2}{*}{$\begin{array}{l}\text { Income-sharing } \\
\text { unit }\end{array}$} & \multirow{2}{*}{$\begin{array}{l}\text { Income } \\
\text { definition }\end{array}$} & \multicolumn{3}{|c|}{ Dataset } \\
\hline & & FRS & $\begin{array}{l}\text { HBAI } \\
\text { (without SPI } \\
\text { adjustments) }\end{array}$ & $\begin{array}{l}\text { HBAI-SPI } \\
\text { (including SPI adjustments) }\end{array}$ \\
\hline \multirow[t]{3}{*}{ Individual } & Market & $\begin{array}{l}\text { Derived by the } \\
\text { authors }\end{array}$ & $\begin{array}{l}\text { Derived by the } \\
\text { authors }\end{array}$ & Derived by the authors \\
\hline & Gross & Available & Unavailable & $\begin{array}{l}\text { Only available for 2005/06 } \\
\text { and later years, but derived } \\
\text { by the authors for earlier } \\
\text { years }\end{array}$ \\
\hline & Net & Available & Unavailable & Unavailable \\
\hline \multirow[t]{3}{*}{ Family } & Market & $\begin{array}{l}\text { Derived by the } \\
\text { authors }\end{array}$ & $\begin{array}{l}\text { Derived by the } \\
\text { authors }\end{array}$ & Derived by the authors \\
\hline & Gross & Available & Available & Available \\
\hline & Net & Unavailable & Available & Available \\
\hline \multirow[t]{3}{*}{ Household } & Market & $\begin{array}{l}\text { Derived by the } \\
\text { authors }\end{array}$ & $\begin{array}{l}\text { Derived by the } \\
\text { authors }\end{array}$ & Derived by the authors \\
\hline & Gross & Available & Available & Available \\
\hline & Net & Unavailable & Available & Available \\
\hline
\end{tabular}

Notes: 'Available' refers to variables either available in the FRS files or variables derived by the DWP and released in the public-use files for each year from 1994/95 through 2012/13. Market income is pre-tax pretransfer income; gross income is pre-tax post-transfer income; net income is post-tax post-transfer income. Variables derived by the authors are explained in the main text. 
Table 2. Percentage growth in equivalised gross household income between 1995/96 and 2007/08: HBAI-SPI versus HBAI-SPI2 estimates, by income group

\begin{tabular}{lcccccccc}
\hline & \multicolumn{2}{c}{$1995 / 96$ to } & \multicolumn{2}{c}{$1995 / 96$ to } & \multicolumn{2}{c}{$2001 / 02$ to } & \multicolumn{2}{c}{$2004 / 05$ to } \\
& \multicolumn{2}{c}{$2007 / 08$} & \multicolumn{2}{c}{ 2001/02 } & \multicolumn{2}{c}{ 2004/05 } & \multicolumn{2}{c}{ 2007/08 } \\
\cline { 2 - 9 } Income group & HBAI- & HBAI- & HBAI- & HBAI- & HBAI- & HBAI- & HBAI- & HBAI- \\
& SPI & SPI2 & SPI & SPI2 & SPI & SPI2 & SPI & SPI2 \\
\hline Poorest fifth & 22.7 & 22.6 & 17.3 & 17.2 & 6.2 & 6.3 & -1.5 & -1.6 \\
$2^{\text {nd }}$ poorest fifth & 30.1 & 29.9 & 22.4 & 22.3 & 5.2 & 5.3 & 1.0 & 0.9 \\
Middle fifth & 25.5 & 25.6 & 19.3 & 19.2 & 3.7 & 3.8 & 1.5 & 1.5 \\
$2^{\text {nd }}$ richest fifth & 24.3 & 24.9 & 17.8 & 17.8 & 3.4 & 3.3 & 2.0 & 2.7 \\
Richest fifth & 38.2 & 45.7 & 28.6 & 28.8 & 0.7 & 0.6 & 6.7 & 12.4 \\
Percentiles 81 to 90 & 25.3 & 27.4 & 19.3 & 19.7 & 1.8 & 1.2 & 3.2 & 5.2 \\
Percentiles 91 to 95 & 27.3 & 31.3 & 21.7 & 22.6 & 1.5 & 0.7 & 3.1 & 6.3 \\
Percentiles 96 to 99 & 41.3 & 46.1 & 28.1 & 29.4 & 2.6 & 0.9 & 7.5 & 11.9 \\
Top 1 percent & 76.1 & 102.3 & 59.3 & 55.0 & -4.4 & -0.3 & 15.7 & 31.0 \\
Median & 25.4 & 25.3 & 19.3 & 20.2 & 3.4 & 3.6 & 1.6 & 1.5 \\
Mean & 31.1 & 34.7 & 23.4 & 22.1 & 2.6 & 2.5 & 3.7 & 6.5 \\
\hline
\end{tabular}

Notes and sources: As for Figure 2. Household income is equivalised using the modified-OECD scale. The individual is the unit of analysis. Estimates are based on the full population (aged less than 15 as well as aged $15+$ ). The price index used is the all items RPI excluding Council tax (agg4111), a bespoke index created for the Department for Work and Pensions by the Office for National Statistics. 
Table 3. Increase in inequality of equivalised gross household income between 1995/96 and 2010/11 according to four inequality indices: HBAI-SPI2 versus HBAI-SPI data

\begin{tabular}{|c|c|c|c|c|c|c|c|c|c|c|}
\hline \multirow[b]{2}{*}{ Inequality index } & \multirow[b]{2}{*}{ Data set } & \multirow[b]{2}{*}{$\begin{array}{l}\text { Income } \\
\text { definition }\end{array}$} & \multicolumn{4}{|c|}{ Level } & \multicolumn{4}{|c|}{ Percentage change } \\
\hline & & & $1995 / 96$ & $2001 / 02$ & 2004/05 & $2007 / 08$ & $\begin{array}{c}1995 / 96 \\
\text { to } \\
2001 / 02\end{array}$ & $\begin{array}{c}2001 / 02 \\
\text { to } \\
2004 / 05\end{array}$ & $\begin{array}{c}2004 / 05 \\
\text { to } \\
2007 / 08\end{array}$ & $\begin{array}{l}1995 / 96 \\
\text { to } \\
2007 / 08\end{array}$ \\
\hline \multirow[t]{3}{*}{ Gini coefficient } & HBAI-SPI2 & Gross & 0.380 & 0.400 & 0.390 & 0.419 & 5.1 & -2.5 & 7.3 & 10.1 \\
\hline & HBAI-SPI & Gross & 0.375 & 0.394 & 0.384 & 0.399 & 5.2 & -2.5 & 4.0 & 6.6 \\
\hline & HBAI-SPI & Net & 0.333 & 0.349 & 0.339 & 0.357 & 4.7 & -2.6 & 5.1 & 7.1 \\
\hline \multirow{3}{*}{$\begin{array}{l}\text { Mean logarithmic } \\
\text { deviation (MLD) }\end{array}$} & HBAI-SPI2 & Gross & 0.245 & 0.275 & 0.261 & 0.305 & 12.2 & -5.2 & 16.9 & 24.3 \\
\hline & HBAI-SPI & Gross & 0.239 & 0.268 & 0.254 & 0.277 & 12.4 & -5.3 & 9.1 & 16.1 \\
\hline & HBAI-SPI & Net & 0.186 & 0.208 & 0.195 & 0.217 & 11.6 & -6.1 & 11.0 & 16.4 \\
\hline \multirow[t]{3}{*}{ Theil index } & HBAI-SPI2 & Gross & 0.275 & 0.333 & 0.317 & 0.396 & 21.3 & -5.0 & 24.9 & 44.0 \\
\hline & HBAI-SPI & Gross & 0.266 & 0.325 & 0.299 & 0.332 & 22.5 & -8.0 & 10.7 & 24.8 \\
\hline & HBAI-SPI & Net & 0.205 & 0.250 & 0.229 & 0.258 & 22.0 & -8.3 & 12.7 & 26.0 \\
\hline \multirow{3}{*}{$\begin{array}{l}\text { Half squared } \\
\text { coefficient of } \\
\text { variation }\end{array}$} & HBAI-SPI2 & Gross & 0.486 & 0.777 & 0.721 & 1.162 & 59.7 & -7.2 & 61.1 & 138.9 \\
\hline & HBAI-SPI & Gross & 0.470 & 0.765 & 0.619 & 0.705 & 62.5 & -19.0 & 13.8 & 49.8 \\
\hline & HBAI-SPI & Net & 0.330 & 0.527 & 0.430 & 0.501 & 59.8 & -18.4 & 16.5 & 52.0 \\
\hline
\end{tabular}

Notes and sources: As for Table 2. 


\title{
APPENDICES
}

\author{
accompanying
}

What has Been Happening to UK Income Inequality Since the Mid-1990s?

Answers from Reconciled and Combined Household Survey and Tax Return Data

by

Burkhauser, Hérault, Jenkins, and Wilkins

3 February 2016 


\section{Appendix A}

Figure A1. Trends in US inequality since 1967

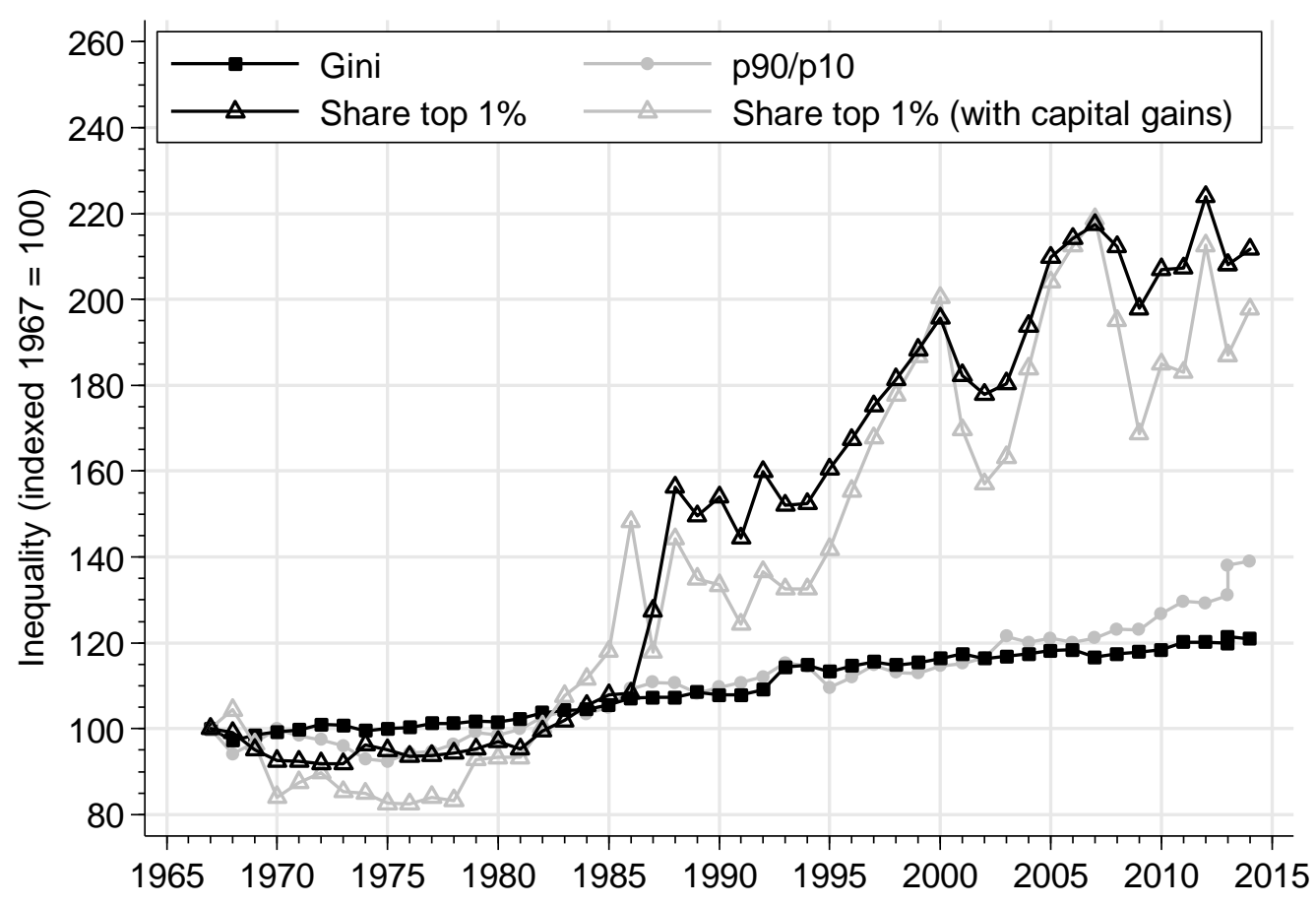

Notes: The Gini and p90/p10 measures are based on Current Population Survey data (source: authors' derivations from De-Nevas Walt and Proctor, 2015, Table A-2). The two top 1\% share measures are based on IRS tax return data (source: authors' derivations from the World Top Incomes Database). There were substantial changes in CPS survey design in 1993 and 2013, and the IRS tax return estimates are affected by the 1986 Tax Reform Act: see Atkinson et al. (2011) and Burkhauser et al. (2012) for detailed discussions. However, between the mid-1990s and 2012, there were no such changes hindering comparability of trends across the two sources. Over this period, the increase in inequality as measured by the change in the top $1 \%$ share was substantially greater than the increased measured by the Gini coefficient or $p 90 / p 10$.

Atkinson, A. B., Piketty, T., and Saez, E. (2011). Top incomes in the long run of history. Journal of Economic Literature, 49 (1), 3-71.

Burkhauser, R.V., Feng, S., Jenkins, S. P., and Larrimore, J. (2012). Recent trends in top income shares in the USA: reconciling estimates from March CPS and IRS tax return data, Review of Economics and Statistics, 94 (2), 371-388.

De-Nevas Walt, C. and Proctor, B. D. (2015). Income and Poverty in the United States: 2014. Washington, DC: US Bureau of the Census.

https://www.census.gov/hhes/www/poverty/data/incpovhlth/2014/index.html 
Appendix B. The SPI adjustment: income thresholds and numbers of eligible individuals (cf. section 2.3)

Table B1. Gross income thresholds for eligibility to the SPI adjustments (pounds per year, nominal)

\begin{tabular}{lrrrc}
\hline Fiscal year & \multicolumn{2}{c}{ Great Britain } & \multicolumn{2}{c}{ Northern Ireland } \\
& Non-pensioners & Pensioners & Non-pensioners & Pensioners \\
\hline $1994 / 95$ & 100,000 & 50,000 & - & - \\
$1995 / 96$ & 100,000 & 100,000 & - & - \\
$1996 / 97$ & 100,000 & 100,000 & - & - \\
$1997 / 98$ & 100,000 & 50,000 & - & - \\
$1998 / 99$ & 150,000 & 75,000 & - & - \\
$1999 / 00$ & 150,000 & 60,000 & - & - \\
$2000 / 01$ & 150,000 & 60,000 & - & - \\
$2001 / 02$ & 150,000 & 60,000 & - & - \\
$2002 / 03$ & 150,000 & 60,000 & 150,000 & 60,000 \\
$2003 / 04$ & 150,000 & 60,000 & 150,000 & 60,000 \\
$2004 / 05$ & 150,000 & 60,000 & 150,000 & 60,000 \\
$2005 / 06$ & 150,000 & 60,000 & 150,000 & 60,000 \\
$2006 / 07$ & 150,000 & 60,000 & 150,000 & 60,000 \\
$2007 / 08$ & 150,000 & 60,000 & 150,000 & 60,000 \\
$2008 / 09$ & 150,000 & 60,000 & 100,000 & 60,000 \\
$2009 / 10$ & 256,136 & 60,347 & 167,133 & 55,253 \\
$2010 / 11$ & 202,952 & 65,321 & 141,044 & 57,091 \\
$2011 / 12$ & 237,136 & 68,601 & 131,732 & 59,731 \\
$2012 / 13$ & 236,694 & 73,631 & 131,166 & 60,088 \\
\hline
\end{tabular}

Notes. In years prior to 2009/10, the thresholds are based on net rather gross income for nonpensioners. For all other years and groups, the thresholds are based on gross income. The Family Resources Survey did not include Northern Ireland before 2002/03.

Source: Department for Work and Pensions (2014, Appendix 2) for 2012/13 and previous HBAI reports for earlier years. 
Table B2. Weighted and unweighted numbers of individuals in HBAI data, by SPIadjustment eligibility (all individuals aged 15 years or more)

\begin{tabular}{|c|c|c|c|c|c|c|}
\hline \multirow[b]{2}{*}{$\begin{array}{c}\text { Fiscal } \\
\text { year }\end{array}$} & \multicolumn{2}{|c|}{ Non SPI-adjusted } & \multicolumn{2}{|c|}{ SPI-adjusted } & \multirow{2}{*}{$\begin{array}{c}\text { Share } \\
\text { (weighted, } \\
\% \text { ) }\end{array}$} & \multirow[b]{2}{*}{$\begin{array}{c}\text { Total } \\
\text { population }\end{array}$} \\
\hline & Weighted & Unweighted & Weighted & Unweighted & & \\
\hline $1994 / 95$ & $44,384,604$ & 48,848 & 77,999 & 77 & 0.18 & $44,462,603$ \\
\hline $1995 / 96$ & $44,508,236$ & 48,524 & 52,004 & 45 & 0.12 & $44,560,241$ \\
\hline $1996 / 97$ & $44,698,884$ & 47,271 & 60,002 & 61 & 0.13 & $44,758,887$ \\
\hline $1997 / 98$ & $44,795,192$ & 43,767 & 116,447 & 98 & 0.26 & $44,911,638$ \\
\hline $1998 / 99$ & $45,010,976$ & 42,414 & 64,001 & 46 & 0.14 & $45,074,975$ \\
\hline $1999 / 00$ & $45,130,540$ & 46,138 & 89,001 & 56 & 0.20 & $45,219,542$ \\
\hline $2000 / 01$ & $45,374,004$ & 43,803 & 109,000 & 84 & 0.24 & $45,483,004$ \\
\hline 2001/02 & $45,546,944$ & 46,723 & 125,008 & 99 & 0.27 & $45,671,954$ \\
\hline $2002 / 03$ & $47,291,028$ & 52,950 & 127,311 & 93 & 0.27 & $47,418,339$ \\
\hline $2003 / 04$ & $47,502,560$ & 52,971 & 133,610 & 115 & 0.28 & $47,636,171$ \\
\hline $2004 / 05$ & $47,813,188$ & 51,390 & 152,601 & 127 & 0.32 & $47,965,790$ \\
\hline 2005/06 & $48,366,940$ & 51,569 & 166,603 & 126 & 0.34 & $48,533,542$ \\
\hline $2006 / 07$ & $48,776,460$ & 47,263 & 203,401 & 131 & 0.42 & $48,979,862$ \\
\hline 2007/08 & $49,282,236$ & 45,537 & 254,401 & 136 & 0.52 & $49,536,637$ \\
\hline 2008/09 & $49,730,852$ & 45,611 & 252,002 & 162 & 0.51 & $49,982,854$ \\
\hline $2009 / 10$ & $50,033,588$ & 45,767 & 249,386 & 149 & 0.50 & $50,282,974$ \\
\hline $2010 / 11$ & $50,516,168$ & 46,309 & 252,496 & 175 & 0.50 & $50,768,665$ \\
\hline 2011/12 & $51,351,512$ & 38,118 & 253,701 & 114 & 0.49 & $51,605,215$ \\
\hline 2012/13 & $51,635,808$ & 36,917 & 256,294 & 112 & 0.50 & $51,892,104$ \\
\hline
\end{tabular}

Source: Authors' calculations based on HBAI data. 


\section{Appendix C. Construction of individual-level HBAI and HBAI-SPI variables (cf.}

Section 2.4)

Figure C1. Median and mean gross and market incomes for HBAI-SPI individual income series (actual post-2005/06 series and imputed 1994/95-2012/13 series), in pounds per week (2012/13 prices)

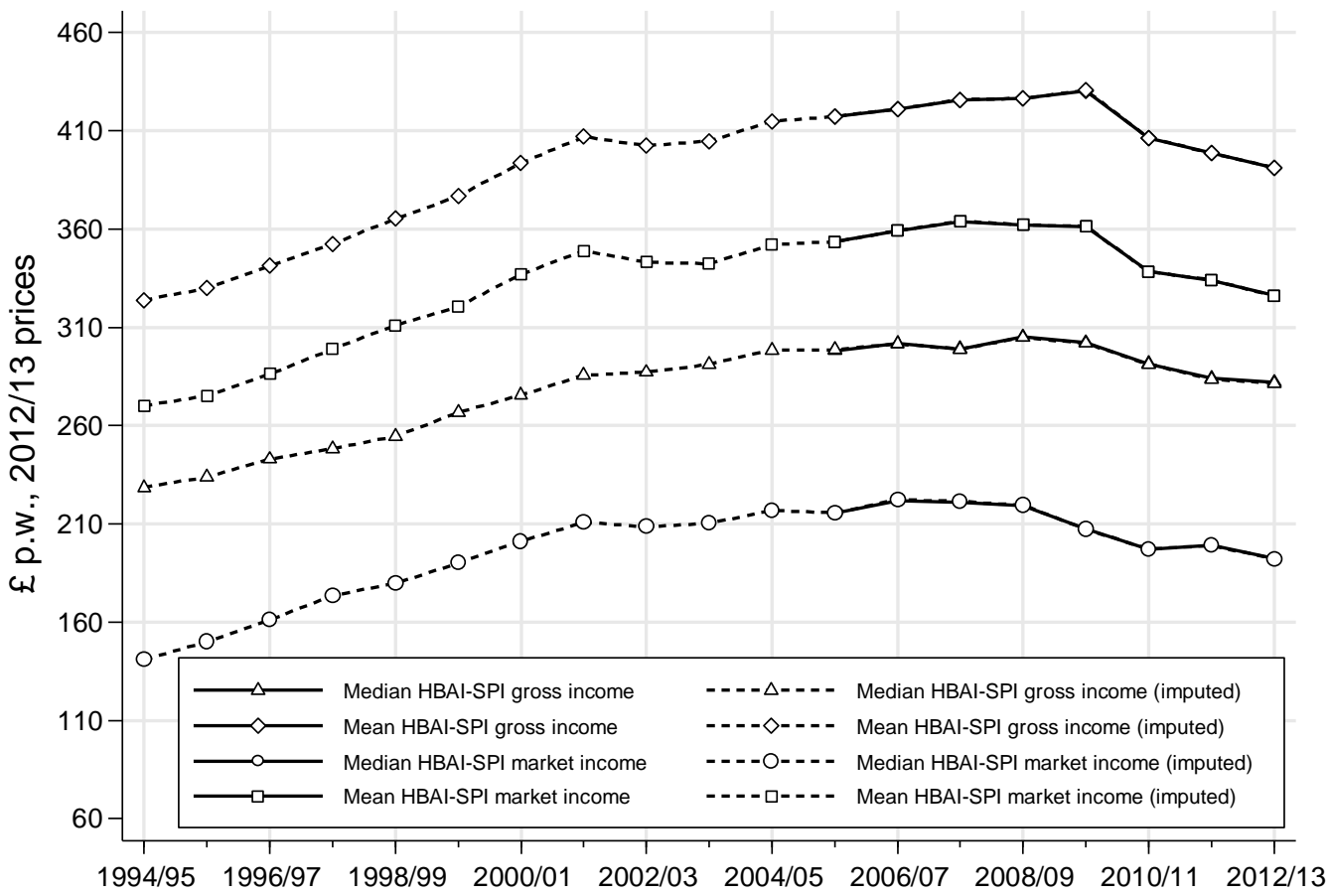

Note: The price index used is the all items RPI excluding Council tax (agg4111), a bespoke index created for the Department for Work and Pensions by the Office for National Statistics. Source: Authors' calculations based on HBAI and FRS data.

(Stata graph mean\&median1) 
Appendix D. WTID and HBAI control totals (cf. section 2.5)

Figure D1. Income control totals: total income (in billions of pounds per year, current prices)

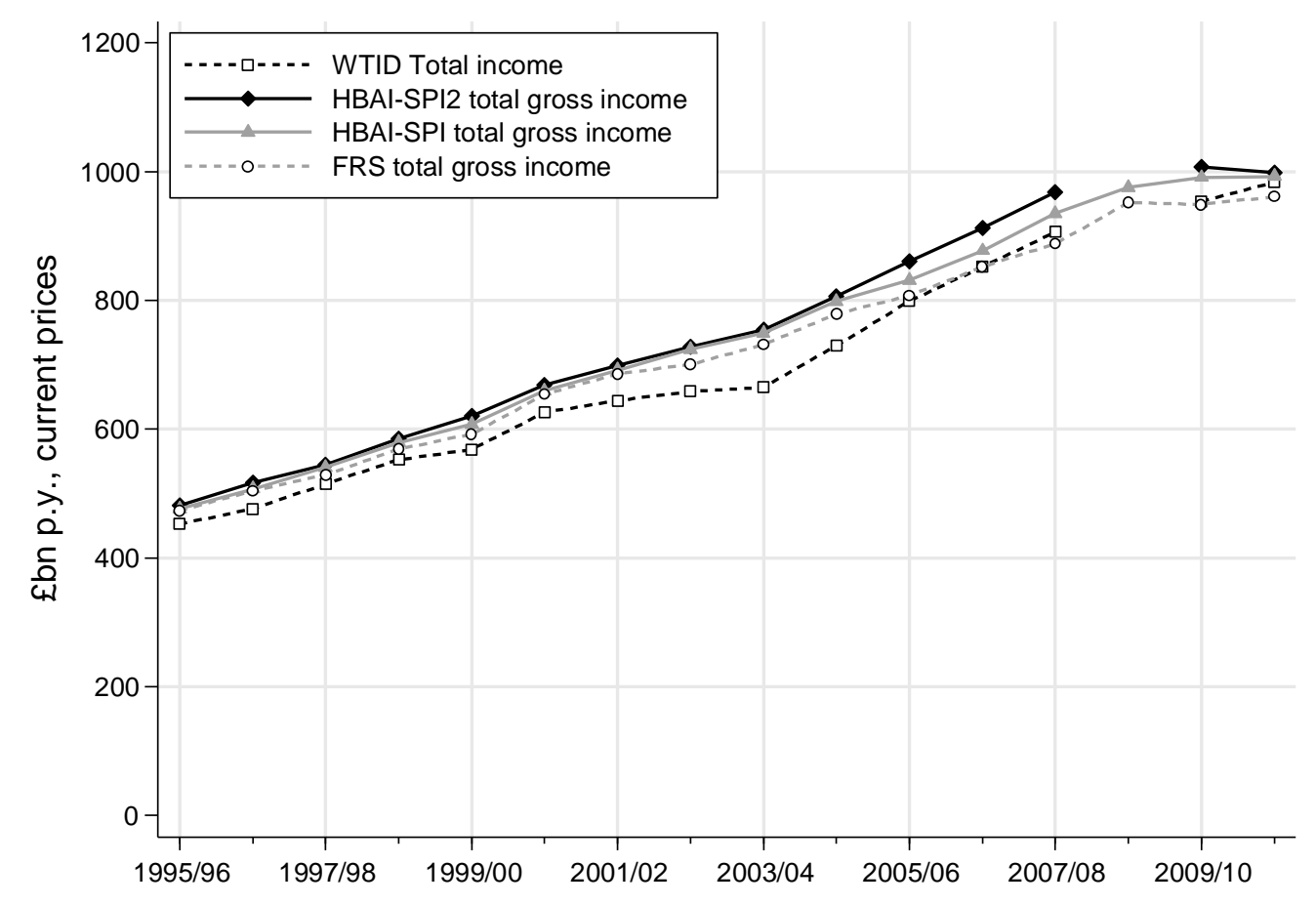

Notes: Northern Ireland is included in the FRS, HBAI-SPI and HBAI-SPI2 data only from 2002/03 onwards. Source: Authors' calculations based on HBAI, FRS, SPI and WTID data. 
Figure D2. Population control totals: number of individuals aged 15+ (millions), HBAI and WTID data

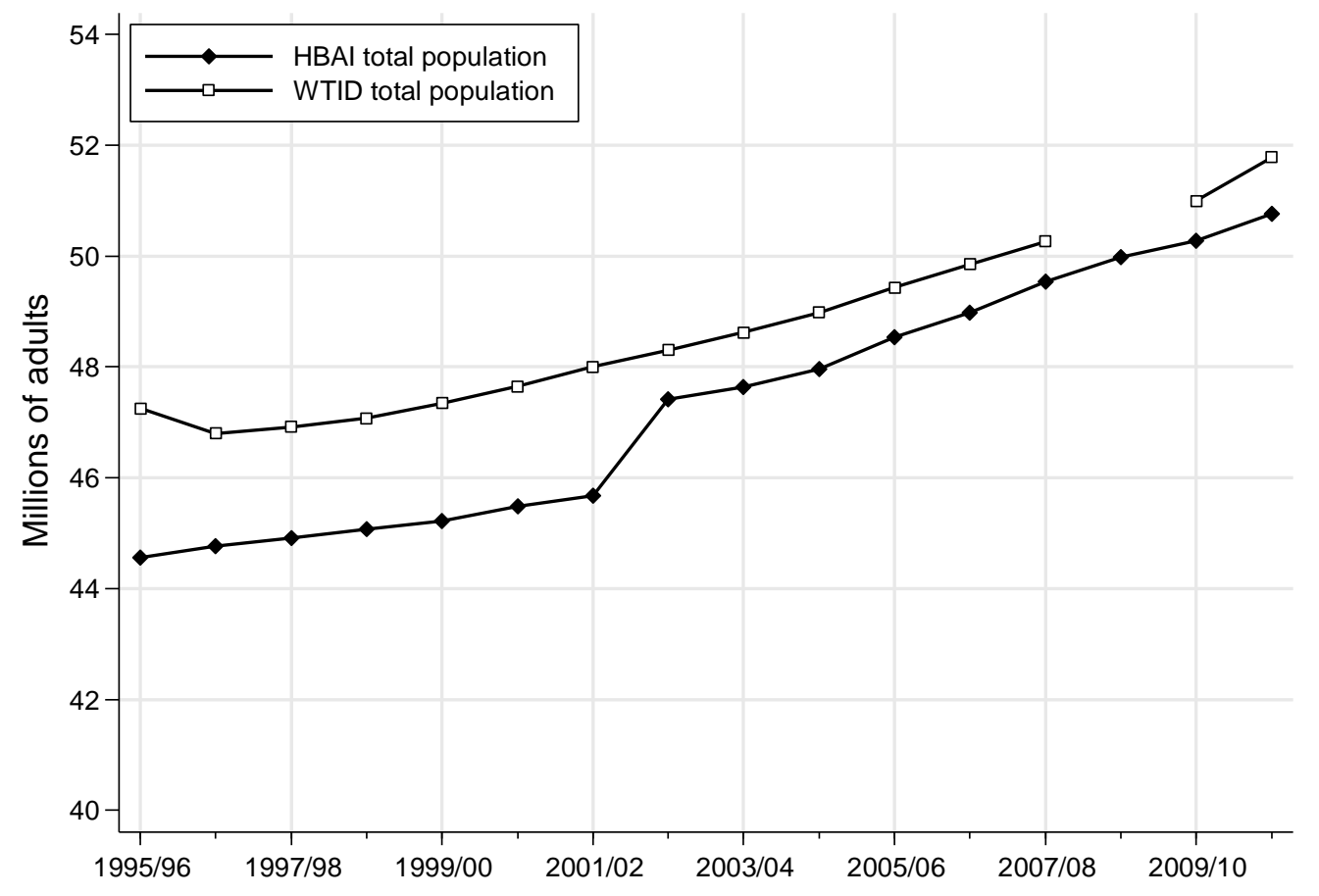

Notes: Northern Ireland is included in the FRS and hence HBAI data only from 2002/03 onwards.

Source: WTID data and authors' calculations based on HBAI data (weighted sum of the population aged 15 and above). 
Appendix E. Additional top income share estimates (cf. sections 3-5)

Figure E1. Top 0.1\% individual income shares: HBAI-SPI, HBAI-SPI2 and SPI/WTID series

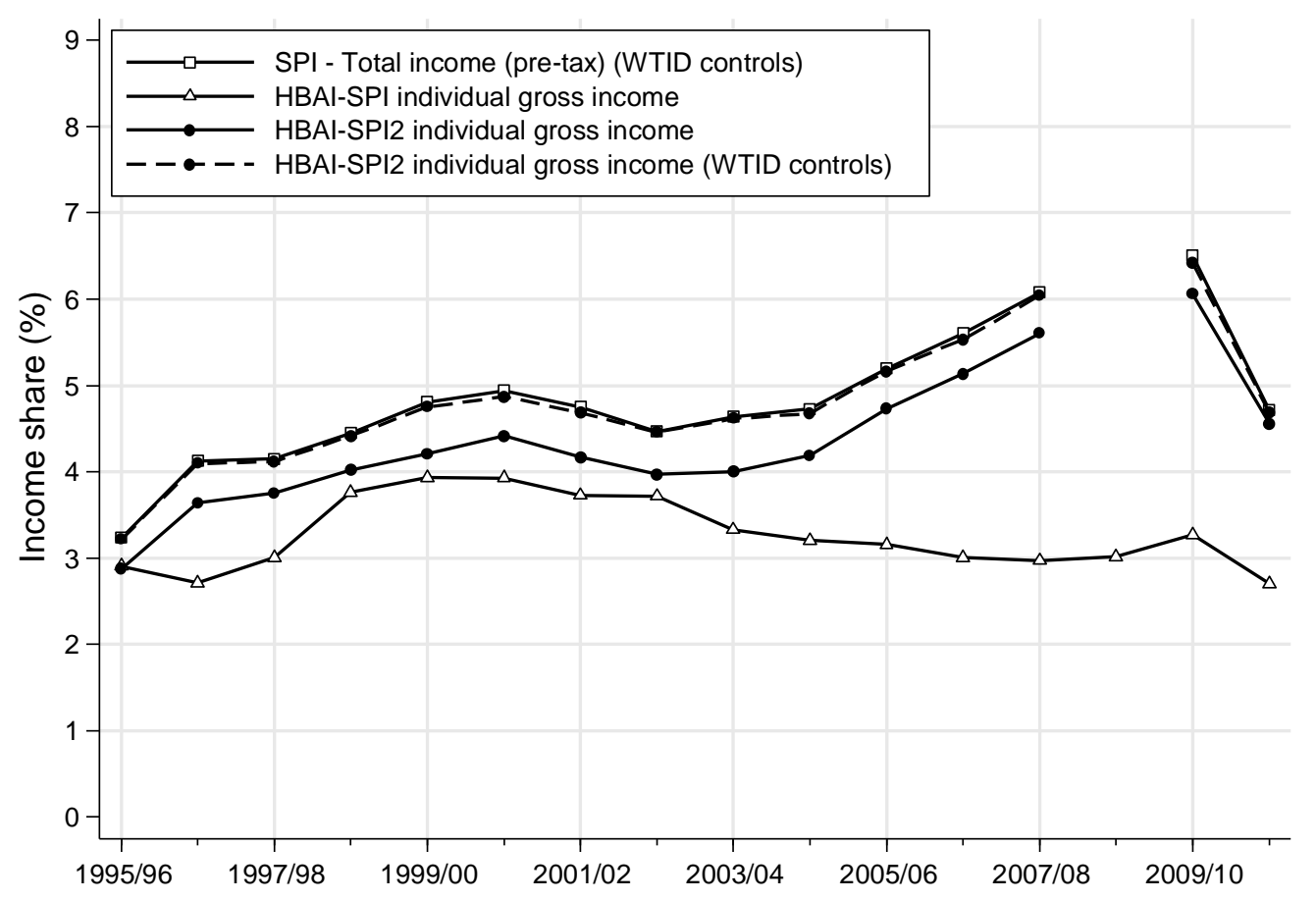

Notes: Northern Ireland is included in the FRS, HBAI-SPI and HBAI-SPI2 series only from 2002/03 onwards. Source: Authors' calculations based on HBAI, FRS, SPI and WTID data.

(Stata graph top01a) 
Figure E2. Top $10 \%$ to $5 \%$ and top $5 \%$ to $1 \%$ individual income shares: HBAI-SPI2 and SPI/WTID series

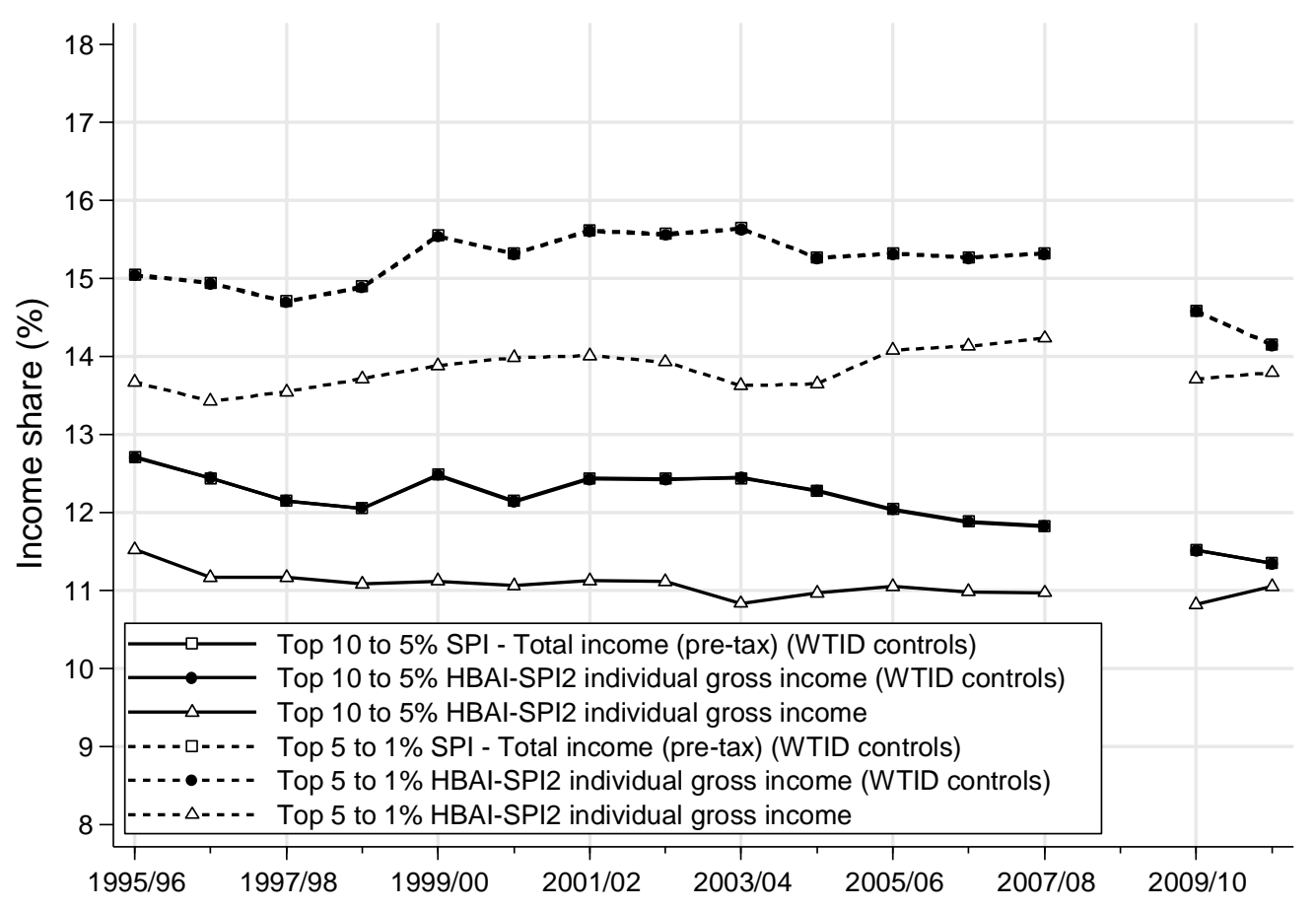

Notes: Northern Ireland is included in the FRS and hence HBAI-SPI2 data only from 2002/03 onwards. Source: Authors' calculations based on HBAI, FRS, SPI and WTID data.

(Stata graph 10-5-1a) 


\section{Appendix F. Top income shares and standard errors}

Table F.1 Top 1\% income shares and standard errors within parentheses

\begin{tabular}{|c|c|c|c|c|c|c|c|c|c|c|c|}
\hline Data set & SPI & HBAI-SPI & HBAI & FRS & $\begin{array}{l}\text { HBAI- } \\
\text { SPI2 }\end{array}$ & $\begin{array}{l}\text { HBAI- } \\
\text { SPI2 }\end{array}$ & $\begin{array}{l}\text { HBAI- } \\
\text { SPI2 }\end{array}$ & $\begin{array}{l}\text { HBAI- } \\
\text { SPI2 }\end{array}$ & $\begin{array}{l}\text { HBAI- } \\
\text { SPI2 }\end{array}$ & HBAI-SPI2 & HBAI-SPI2 \\
\hline $\begin{array}{l}\text { Income } \\
\text { definition }\end{array}$ & $\begin{array}{c}\text { Gross } \\
\text { income }\end{array}$ & $\begin{array}{l}\text { Gross } \\
\text { income }\end{array}$ & $\begin{array}{c}\text { Gross } \\
\text { income }\end{array}$ & $\begin{array}{l}\text { Gross } \\
\text { income }\end{array}$ & $\begin{array}{c}\text { Gross } \\
\text { income }\end{array}$ & $\begin{array}{c}\text { Gross } \\
\text { income }\end{array}$ & $\begin{array}{l}\text { Market } \\
\text { income }\end{array}$ & $\begin{array}{l}\text { Gross } \\
\text { income }\end{array}$ & $\begin{array}{l}\text { Market } \\
\text { income }\end{array}$ & $\begin{array}{c}\text { Gross } \\
\text { income }\end{array}$ & $\begin{array}{l}\text { Equivalised } \\
\text { gross } \\
\text { income }\end{array}$ \\
\hline Unit & Individual & Individual & Individual & Individual & Individual & Individual & Individual & Family & Family & Household & Household \\
\hline $\begin{array}{l}\text { Population } \\
\text { control }\end{array}$ & WTID & HBAI & HBAI & HBAI & HBAI & WTID & HBAI & HBAI & HBAI & HBAI & HBAI \\
\hline \multirow[t]{2}{*}{$\begin{array}{l}\text { Income } \\
\text { control }\end{array}$} & WTID & HBAI-SPI & HBAI & FRS & $\begin{array}{c}\text { HBAI- } \\
\text { SPI2 }\end{array}$ & WTID & $\begin{array}{l}\text { HBAI- } \\
\text { SPI2 }\end{array}$ & $\begin{array}{l}\text { HBAI- } \\
\text { SPI2 }\end{array}$ & $\begin{array}{l}\text { HBAI- } \\
\text { SPI2 }\end{array}$ & HBAI-SPI2 & HBAI-SPI2 \\
\hline & $(1)$ & $(2)$ & (3) & (4) & (5) & (6) & (7) & (8) & (9) & (10) & (11) \\
\hline 1994/95 & & $\begin{array}{c}9.05 \\
(0.30)\end{array}$ & $\begin{array}{c}8.50 \\
(0.34)\end{array}$ & $\begin{array}{c}8.50 \\
(0.31)\end{array}$ & & & & & & & \\
\hline 1995/96 & $\begin{array}{l}10.75 \\
(1.66)\end{array}$ & $\begin{array}{c}9.28 \\
(0.37)\end{array}$ & $\begin{array}{c}8.01 \\
(0.24)\end{array}$ & $\begin{array}{c}8.00 \\
(0.24)\end{array}$ & $\begin{array}{c}9.77 \\
(0.34)\end{array}$ & $\begin{array}{l}10.71 \\
(0.51)\end{array}$ & $\begin{array}{l}11.63 \\
(0.40)\end{array}$ & $\begin{array}{c}8.66 \\
(0.34)\end{array}$ & $\begin{array}{l}10.27 \\
(0.40)\end{array}$ & $\begin{array}{c}7.85 \\
(0.34)\end{array}$ & $\begin{array}{c}7.41 \\
(0.30)\end{array}$ \\
\hline 1996/97 & $\begin{array}{l}11.90 \\
(1.60)\end{array}$ & $\begin{array}{c}9.12 \\
(0.34)\end{array}$ & $\begin{array}{c}8.26 \\
(0.41)\end{array}$ & $\begin{array}{c}8.30 \\
(0.41)\end{array}$ & $\begin{array}{l}10.72 \\
(0.44)\end{array}$ & $\begin{array}{l}11.87 \\
(0.55)\end{array}$ & $\begin{array}{l}12.67 \\
(0.51)\end{array}$ & $\begin{array}{c}9.63 \\
(0.43)\end{array}$ & $\begin{array}{l}11.35 \\
(0.50)\end{array}$ & $\begin{array}{c}8.79 \\
(0.42)\end{array}$ & $\begin{array}{c}8.32 \\
(0.39)\end{array}$ \\
\hline 1997/98 & $\begin{array}{l}12.07 \\
(1.35)\end{array}$ & $\begin{array}{l}10.44 \\
(0.41)\end{array}$ & $\begin{array}{c}8.71 \\
(0.28)\end{array}$ & $\begin{array}{c}8.71 \\
(0.28)\end{array}$ & $\begin{array}{l}11.12 \\
(0.49)\end{array}$ & $\begin{array}{l}12.03 \\
(0.58)\end{array}$ & $\begin{array}{l}13.03 \\
(0.56)\end{array}$ & $\begin{array}{c}9.83 \\
(0.47)\end{array}$ & $\begin{array}{l}11.50 \\
(0.54)\end{array}$ & $\begin{array}{c}8.99 \\
(0.46)\end{array}$ & $\begin{array}{c}8.77 \\
(0.49)\end{array}$ \\
\hline 1998/99 & $\begin{array}{l}12.56 \\
(1.25)\end{array}$ & $\begin{array}{l}10.51 \\
(0.56)\end{array}$ & $\begin{array}{c}9.22 \\
(0.47)\end{array}$ & $\begin{array}{c}9.18 \\
(0.47)\end{array}$ & $\begin{array}{l}11.56 \\
(0.51)\end{array}$ & $\begin{array}{l}12.50 \\
(0.60)\end{array}$ & $\begin{array}{l}13.49 \\
(0.58)\end{array}$ & $\begin{array}{l}10.29 \\
(0.52)\end{array}$ & $\begin{array}{l}11.98 \\
(0.59)\end{array}$ & $\begin{array}{c}9.44 \\
(0.51)\end{array}$ & $\begin{array}{c}9.24 \\
(0.53)\end{array}$ \\
\hline 1999/00 & $\begin{array}{l}13.26 \\
(1.33)\end{array}$ & $\begin{array}{l}10.81 \\
(0.58)\end{array}$ & $\begin{array}{c}8.79 \\
(0.37)\end{array}$ & $\begin{array}{c}8.79 \\
(0.37)\end{array}$ & $\begin{array}{l}11.83 \\
(0.52)\end{array}$ & $\begin{array}{l}13.20 \\
(0.65)\end{array}$ & $\begin{array}{l}13.79 \\
(0.60)\end{array}$ & $\begin{array}{l}10.66 \\
(0.52)\end{array}$ & $\begin{array}{l}12.40 \\
(0.59)\end{array}$ & $\begin{array}{c}9.82 \\
(0.50)\end{array}$ & $\begin{array}{c}9.68 \\
(0.56)\end{array}$ \\
\hline $2000 / 01$ & $\begin{array}{l}13.51 \\
(1.23)\end{array}$ & $\begin{array}{l}11.66 \\
(0.54)\end{array}$ & $\begin{array}{l}11.60 \\
(0.86)\end{array}$ & $\begin{array}{l}11.44 \\
(0.86)\end{array}$ & $\begin{array}{l}12.31 \\
(0.58)\end{array}$ & $\begin{array}{l}13.43 \\
(0.69)\end{array}$ & $\begin{array}{l}14.27 \\
(0.66)\end{array}$ & $\begin{array}{l}11.02 \\
(0.56)\end{array}$ & $\begin{array}{l}12.74 \\
(0.64)\end{array}$ & $\begin{array}{l}10.25 \\
(0.56)\end{array}$ & $\begin{array}{l}10.07 \\
(0.61)\end{array}$ \\
\hline 2001/02 & $\begin{array}{l}13.40 \\
(1.19)\end{array}$ & $\begin{array}{l}11.65 \\
(0.60)\end{array}$ & $\begin{array}{l}11.04 \\
(1.39)\end{array}$ & $\begin{array}{l}11.08 \\
(1.39)\end{array}$ & $\begin{array}{l}12.00 \\
(0.50)\end{array}$ & $\begin{array}{l}13.32 \\
(0.65)\end{array}$ & $\begin{array}{l}13.91 \\
(0.57)\end{array}$ & $\begin{array}{l}10.72 \\
(0.50)\end{array}$ & $\begin{array}{l}12.40 \\
(0.57)\end{array}$ & $\begin{array}{c}9.81 \\
(0.49)\end{array}$ & $\begin{array}{c}9.72 \\
(0.53)\end{array}$ \\
\hline $2002 / 03$ & $\begin{array}{l}13.02 \\
(1.14)\end{array}$ & $\begin{array}{l}11.49 \\
(0.61)\end{array}$ & $\begin{array}{c}8.78 \\
(0.31)\end{array}$ & $\begin{array}{c}8.83 \\
(0.32)\end{array}$ & $\begin{array}{l}11.65 \\
(0.49)\end{array}$ & $\begin{array}{l}13.00 \\
(0.56)\end{array}$ & $\begin{array}{l}13.58 \\
(0.56)\end{array}$ & $\begin{array}{l}10.36 \\
(0.47)\end{array}$ & $\begin{array}{l}12.05 \\
(0.54)\end{array}$ & $\begin{array}{c}9.46 \\
(0.47)\end{array}$ & $\begin{array}{c}8.99 \\
(0.46)\end{array}$ \\
\hline 2003/04 & 13.29 & 10.80 & 8.90 & 8.91 & 11.57 & 13.25 & 13.57 & 10.26 & 12.01 & 9.35 & 9.04 \\
\hline
\end{tabular}

\footnotetext{
APPENDICES - 9
} 


\begin{tabular}{|c|c|c|c|c|c|c|c|c|c|c|c|}
\hline \multirow{3}{*}{$2004 / 05$} & (1.25) & $(0.52)$ & $(0.37)$ & $(0.37)$ & $(0.47)$ & $(0.55)$ & $(0.54)$ & $(0.47)$ & $(0.54)$ & $(0.46)$ & $(0.48)$ \\
\hline & 13.34 & 11.20 & 8.88 & 9.25 & 11.89 & 13.27 & 13.91 & 10.54 & 12.30 & 9.59 & 9.53 \\
\hline & (1.21) & $(0.52)$ & $(0.31)$ & (0.38) & $(0.50)$ & $(0.57)$ & $(0.57)$ & $(0.48)$ & (0.55) & $(0.47)$ & $(0.51)$ \\
\hline \multirow[t]{2}{*}{$2005 / 06$} & 14.26 & 11.17 & 10.93 & 9.05 & 13.09 & 14.22 & 15.29 & 11.81 & 13.76 & 10.70 & 10.39 \\
\hline & $(1.22)$ & $(0.50)$ & (1.54) & $(0.31)$ & $(0.53)$ & (0.59) & $(0.61)$ & $(0.52)$ & (0.60) & $(0.51)$ & $(0.55)$ \\
\hline \multirow[t]{2}{*}{$2006 / 07$} & 14.92 & 11.60 & 9.53 & 9.56 & 13.75 & 14.83 & 15.93 & 12.33 & 14.26 & 11.20 & 10.87 \\
\hline & (1.24) & $(0.54)$ & (0.38) & (0.38) & $(0.66)$ & $(0.71)$ & $(0.74)$ & $(0.71)$ & $(0.81)$ & $(0.71)$ & $(0.65)$ \\
\hline \multirow[t]{2}{*}{ 2007/08 } & 15.51 & 12.44 & 9.34 & 8.64 & 14.38 & 15.46 & 16.66 & 12.91 & 14.92 & 11.86 & 11.37 \\
\hline & $(1.20)$ & $(0.62)$ & $(0.36)$ & $(0.25)$ & $(0.76)$ & $(0.82)$ & $(0.86)$ & $(0.81)$ & $(0.92)$ & $(0.80)$ & $(0.80)$ \\
\hline \multirow[t]{2}{*}{ 2008/09 } & & 12.46 & 11.46 & 10.94 & & & & & & & \\
\hline & & $(0.65)$ & (2.23) & (2.24) & & & & & & & \\
\hline \multirow[t]{2}{*}{$2009 / 10$} & 15.47 & 13.12 & 10.04 & 9.66 & 14.47 & 15.36 & 17.10 & 13.17 & 15.53 & 12.14 & 11.15 \\
\hline & $(0.76)$ & $(0.78)$ & $(0.48)$ & $(0.43)$ & $(0.85)$ & $(0.90)$ & (0.97) & $(0.85)$ & (0.98) & $(0.85)$ & $(0.80)$ \\
\hline \multirow[t]{2}{*}{$2010 / 11$} & 12.61 & 11.63 & 10.06 & 8.98 & 12.28 & 12.57 & 14.63 & 11.04 & 13.12 & 10.07 & 9.62 \\
\hline & $(0.56)$ & $(0.47)$ & $(0.45)$ & $(0.28)$ & $(0.56)$ & $(0.58)$ & $(0.65)$ & (0.59) & (0.68) & $(0.58)$ & $(0.54)$ \\
\hline \multirow[t]{2}{*}{ 2011/12 } & & 12.35 & 8.89 & 9.66 & & & & & & & \\
\hline & & $(0.72)$ & $(0.37)$ & $(0.41)$ & & & & & & & \\
\hline \multirow[t]{2}{*}{$2012 / 13$} & & 11.81 & 9.09 & 9.52 & & & & & & & \\
\hline & & (0.69) & $(0.47)$ & $(0.29)$ & & & & & & & \\
\hline
\end{tabular}

Notes: Northern Ireland is included in the FRS and hence HBAI data only from 2002/03 onwards.

Source: Authors' calculations based on HBAI, FRS, SPI and WTID data. Household income is equivalised using the modified-OECD scale. The individual is the unit of analysis. Estimates are based on the full population. The definition of the 'family' is the 'benefit unit' (see Department for Work and Pensions 2015) 
Table F.2 Top $0.1 \%$ income shares and standard errors within parentheses

\begin{tabular}{|c|c|c|c|c|c|c|c|c|c|c|c|}
\hline Data set & SPI & HBAI-SPI & HBAI & FRS & $\begin{array}{c}\text { HBAI- } \\
\text { SPI2 }\end{array}$ & $\begin{array}{c}\text { HBAI- } \\
\text { SPI2 }\end{array}$ & $\begin{array}{c}\text { HBAI- } \\
\text { SPI2 }\end{array}$ & $\begin{array}{l}\text { HBAI- } \\
\text { SPI2 }\end{array}$ & $\begin{array}{l}\text { HBAI- } \\
\text { SPI2 }\end{array}$ & HBAI-SPI2 & HBAI-SPI2 \\
\hline $\begin{array}{l}\text { Income } \\
\text { definition }\end{array}$ & $\begin{array}{c}\text { Gross } \\
\text { income }\end{array}$ & $\begin{array}{c}\text { Gross } \\
\text { income }\end{array}$ & $\begin{array}{c}\text { Gross } \\
\text { income }\end{array}$ & $\begin{array}{c}\text { Gross } \\
\text { income }\end{array}$ & $\begin{array}{c}\text { Gross } \\
\text { income }\end{array}$ & $\begin{array}{c}\text { Gross } \\
\text { income }\end{array}$ & $\begin{array}{l}\text { Market } \\
\text { income }\end{array}$ & $\begin{array}{c}\text { Gross } \\
\text { income }\end{array}$ & $\begin{array}{l}\text { Market } \\
\text { income }\end{array}$ & $\begin{array}{c}\text { Gross } \\
\text { income }\end{array}$ & $\begin{array}{c}\text { Equivalised } \\
\text { gross } \\
\text { income }\end{array}$ \\
\hline Unit & Individual & Individual & Individual & Individual & Individual & Individual & Individual & Family & $\begin{array}{c}\text { Benefit } \\
\text { Unit }\end{array}$ & Household & Household \\
\hline $\begin{array}{l}\text { Population } \\
\text { control }\end{array}$ & WTID & HBAI & HBAI & HBAI & HBAI & WTID & HBAI & HBAI & HBAI & HBAI & HBAI \\
\hline \multirow[t]{2}{*}{$\begin{array}{l}\text { Income } \\
\text { control }\end{array}$} & WTID & HBAI-SPI & HBAI & FRS & $\begin{array}{c}\text { HBAI- } \\
\text { SPI2 }\end{array}$ & WTID & $\begin{array}{c}\text { HBAI- } \\
\text { SPI2 }\end{array}$ & $\begin{array}{l}\text { HBAI- } \\
\text { SPI2 }\end{array}$ & $\begin{array}{l}\text { HBAI- } \\
\text { SPI2 }\end{array}$ & HBAI-SPI2 & HBAI-SPI2 \\
\hline & $(1)$ & $(2)$ & $(3)$ & (4) & (5) & $(6)$ & $(7)$ & $(8)$ & (9) & $(10)$ & (11) \\
\hline $1994 / 95$ & & $\begin{array}{c}2.74 \\
(0.19)\end{array}$ & $\begin{array}{c}2.17 \\
(0.27)\end{array}$ & $\begin{array}{c}2.07 \\
(0.23)\end{array}$ & & & & & & & \\
\hline 1995/96 & $\begin{array}{c}3.24 \\
(0.81)\end{array}$ & $\begin{array}{c}2.91 \\
(0.15)\end{array}$ & $\begin{array}{c}1.89 \\
(0.16)\end{array}$ & $\begin{array}{c}1.90 \\
(0.16)\end{array}$ & $\begin{array}{c}2.87 \\
(0.02)\end{array}$ & $\begin{array}{c}3.22 \\
(0.26)\end{array}$ & $\begin{array}{c}3.42 \\
(0.03)\end{array}$ & $\begin{array}{c}2.12 \\
(0.09)\end{array}$ & $\begin{array}{c}2.52 \\
(0.10)\end{array}$ & $\begin{array}{c}1.77 \\
(0.09)\end{array}$ & $\begin{array}{c}1.71 \\
(0.08)\end{array}$ \\
\hline 1996/97 & $\begin{array}{c}4.13 \\
(0.89)\end{array}$ & $\begin{array}{c}2.71 \\
(0.02)\end{array}$ & $\begin{array}{c}2.19 \\
(0.37)\end{array}$ & $\begin{array}{c}2.20 \\
(0.36)\end{array}$ & $\begin{array}{c}3.64 \\
(0.03)\end{array}$ & $\begin{array}{c}4.10 \\
(0.36)\end{array}$ & $\begin{array}{c}4.31 \\
(0.04)\end{array}$ & $\begin{array}{c}2.54 \\
(0.07)\end{array}$ & $\begin{array}{c}3.00 \\
(0.08)\end{array}$ & $\begin{array}{c}2.11 \\
(0.07)\end{array}$ & $\begin{array}{c}2.13 \\
(0.17)\end{array}$ \\
\hline 1997/98 & $\begin{array}{c}4.15 \\
(0.64)\end{array}$ & $\begin{array}{c}3.00 \\
(0.02)\end{array}$ & $\begin{array}{c}2.18 \\
(0.14)\end{array}$ & $\begin{array}{c}2.19 \\
(0.14)\end{array}$ & $\begin{array}{c}3.75 \\
(0.03)\end{array}$ & $\begin{array}{c}4.12 \\
(0.39)\end{array}$ & $\begin{array}{c}4.40 \\
(0.04)\end{array}$ & $\begin{array}{c}2.55 \\
(0.05)\end{array}$ & $\begin{array}{c}2.99 \\
(0.06)\end{array}$ & $\begin{array}{c}2.13 \\
(0.05)\end{array}$ & $\begin{array}{c}2.42 \\
(0.18)\end{array}$ \\
\hline 1998/99 & $\begin{array}{c}4.45 \\
(0.64)\end{array}$ & $\begin{array}{c}3.76 \\
(0.40)\end{array}$ & $\begin{array}{c}2.80 \\
(0.41)\end{array}$ & $\begin{array}{c}2.80 \\
(0.41)\end{array}$ & $\begin{array}{c}4.02 \\
(0.03)\end{array}$ & $\begin{array}{c}4.42 \\
(0.41)\end{array}$ & $\begin{array}{c}4.70 \\
(0.05)\end{array}$ & $\begin{array}{c}2.90 \\
(0.14)\end{array}$ & $\begin{array}{c}3.39 \\
(0.16)\end{array}$ & $\begin{array}{c}2.44 \\
(0.13)\end{array}$ & $\begin{array}{c}2.63 \\
(0.19)\end{array}$ \\
\hline 1999/00 & $\begin{array}{c}4.81 \\
(0.64)\end{array}$ & $\begin{array}{c}3.94 \\
(0.38)\end{array}$ & $\begin{array}{c}2.49 \\
(0.29)\end{array}$ & $\begin{array}{c}2.49 \\
(0.29)\end{array}$ & $\begin{array}{c}4.21 \\
(0.03)\end{array}$ & $\begin{array}{c}4.75 \\
(0.45)\end{array}$ & $\begin{array}{c}4.92 \\
(0.04)\end{array}$ & $\begin{array}{c}2.92 \\
(0.05)\end{array}$ & $\begin{array}{c}3.41 \\
(0.06)\end{array}$ & $\begin{array}{c}2.44 \\
(0.05)\end{array}$ & $\begin{array}{c}2.81 \\
(0.14)\end{array}$ \\
\hline $2000 / 01$ & $\begin{array}{c}4.94 \\
(0.58)\end{array}$ & $\begin{array}{c}3.93 \\
(0.03)\end{array}$ & $\begin{array}{c}4.87 \\
(0.78)\end{array}$ & $\begin{array}{c}4.76 \\
(0.78)\end{array}$ & $\begin{array}{c}4.42 \\
(0.05)\end{array}$ & $\begin{array}{c}4.87 \\
(0.48)\end{array}$ & $\begin{array}{c}5.13 \\
(0.06)\end{array}$ & $\begin{array}{c}2.97 \\
(0.04)\end{array}$ & $\begin{array}{c}3.44 \\
(0.05)\end{array}$ & $\begin{array}{c}2.48 \\
(0.04)\end{array}$ & $\begin{array}{c}3.04 \\
(0.28)\end{array}$ \\
\hline $2001 / 02$ & $\begin{array}{c}4.75 \\
(0.54)\end{array}$ & $\begin{array}{c}3.73 \\
(0.03)\end{array}$ & $\begin{array}{c}4.58 \\
(1.45)\end{array}$ & $\begin{array}{c}4.59 \\
(1.44)\end{array}$ & $\begin{array}{c}4.17 \\
(0.03)\end{array}$ & $\begin{array}{c}4.68 \\
(0.42)\end{array}$ & $\begin{array}{c}4.84 \\
(0.05)\end{array}$ & $\begin{array}{c}2.90 \\
(0.10)\end{array}$ & $\begin{array}{c}3.37 \\
(0.11)\end{array}$ & $\begin{array}{c}2.40 \\
(0.10)\end{array}$ & $\begin{array}{c}2.82 \\
(0.21)\end{array}$ \\
\hline 2002/03 & $\begin{array}{c}4.47 \\
(0.50)\end{array}$ & $\begin{array}{c}3.72 \\
(0.03)\end{array}$ & $\begin{array}{c}2.35 \\
(0.21)\end{array}$ & $\begin{array}{c}2.36 \\
(0.21)\end{array}$ & $\begin{array}{c}3.97 \\
(0.04)\end{array}$ & $\begin{array}{c}4.46 \\
(0.40)\end{array}$ & $\begin{array}{c}4.63 \\
(0.04)\end{array}$ & $\begin{array}{c}2.64 \\
(0.02)\end{array}$ & $\begin{array}{c}3.07 \\
(0.03)\end{array}$ & $\begin{array}{c}2.19 \\
(0.03)\end{array}$ & $\begin{array}{c}2.40 \\
(0.19)\end{array}$ \\
\hline $2003 / 04$ & $\begin{array}{c}4.64 \\
(0.55)\end{array}$ & $\begin{array}{c}3.33 \\
(0.03)\end{array}$ & $\begin{array}{c}2.63 \\
(0.29)\end{array}$ & $\begin{array}{c}2.63 \\
(0.29)\end{array}$ & $\begin{array}{c}4.00 \\
(0.13)\end{array}$ & $\begin{array}{c}4.62 \\
(0.40)\end{array}$ & $\begin{array}{c}4.70 \\
(0.15)\end{array}$ & $\begin{array}{c}2.84 \\
(0.11)\end{array}$ & $\begin{array}{c}3.33 \\
(0.13)\end{array}$ & $\begin{array}{c}2.36 \\
(0.11)\end{array}$ & $\begin{array}{c}2.58 \\
(0.18)\end{array}$ \\
\hline
\end{tabular}

APPENDICES - 11 


\begin{tabular}{|c|c|c|c|c|c|c|c|c|c|c|c|}
\hline \multirow[t]{2}{*}{ 2004/05 } & 4.73 & 3.20 & 2.39 & 2.75 & 4.19 & 4.68 & 4.91 & 2.85 & 3.34 & 2.34 & 2.77 \\
\hline & $(0.58)$ & $(0.03)$ & $(0.21)$ & $(0.30)$ & $(0.32)$ & $(0.42)$ & (0.37) & $(0.04)$ & $(0.05)$ & $(0.04)$ & $(0.22)$ \\
\hline \multirow[t]{2}{*}{ 2005/06 } & 5.20 & 3.15 & 4.61 & 2.59 & 4.73 & 5.16 & 5.54 & 3.29 & 3.84 & 2.68 & 3.13 \\
\hline & $(0.62)$ & $(0.03)$ & (1.61) & $(0.20)$ & $(0.22)$ & $(0.44)$ & $(0.26)$ & $(0.08)$ & $(0.10)$ & $(0.08)$ & $(0.20)$ \\
\hline \multirow[t]{2}{*}{ 2006/07 } & 5.61 & 3.01 & 2.70 & 2.72 & 5.14 & 5.53 & 5.96 & 3.80 & 4.40 & 3.15 & 3.30 \\
\hline & $(0.64)$ & $(0.03)$ & $(0.24)$ & $(0.25)$ & $(0.51)$ & $(0.54)$ & $(0.58)$ & $(0.25)$ & $(0.29)$ & $(0.25)$ & $(0.27)$ \\
\hline \multirow[t]{2}{*}{ 2007/08 } & 6.08 & 2.97 & 2.48 & 1.78 & 5.60 & 6.04 & 6.50 & 4.00 & 4.64 & 3.32 & 3.67 \\
\hline & $(0.64)$ & $(0.03)$ & $(0.21)$ & $(0.13)$ & $(0.44)$ & $(0.65)$ & $(0.50)$ & $(0.25)$ & $(0.29)$ & $(0.25)$ & $(0.34)$ \\
\hline \multirow[t]{2}{*}{ 2008/09 } & & 3.01 & 5.00 & 4.40 & & & & & & & \\
\hline & & $(0.03)$ & (2.35) & (2.37) & & & & & & & \\
\hline \multirow[t]{2}{*}{ 2009/10 } & 6.50 & 3.27 & 3.18 & 2.69 & 6.06 & 6.42 & 7.17 & 4.23 & 5.00 & 3.52 & 3.62 \\
\hline & $(0.58)$ & $(0.04)$ & $(0.34)$ & $(0.34)$ & (0.69) & $(0.73)$ & $(0.81)$ & $(0.13)$ & $(0.15)$ & $(0.13)$ & $(0.29)$ \\
\hline \multirow[t]{2}{*}{ 2010/11 } & 4.72 & 2.70 & 3.29 & 1.92 & 4.56 & 4.69 & 5.44 & 3.26 & 3.88 & 2.69 & 2.75 \\
\hline & $(0.26)$ & $(0.02)$ & $(0.34)$ & $(0.17)$ & $(0.22)$ & $(0.44)$ & $(0.25)$ & $(0.16)$ & $(0.19)$ & $(0.16)$ & $(0.15)$ \\
\hline \multirow[t]{2}{*}{ 2011/12 } & & 3.05 & 2.35 & 1.73 & & & & & & & \\
\hline & & $(0.04)$ & $(0.24)$ & $(0.17)$ & & & & & & & \\
\hline \multirow[t]{2}{*}{ 2012/13 } & & 2.66 & 2.44 & 1.73 & & & & & & & \\
\hline & & $(0.03)$ & $(0.36)$ & $(0.14)$ & & & & & & & \\
\hline
\end{tabular}

Source: Authors' calculations based on HBAI, FRS, SPI and WTID data. Household income is equivalised using the modified-OECD scale. The individual is the unit of analysis.

Estimates are based on the full population. The definition of the 'family' is the 'benefit unit' (see Department for Work and Pensions 2015) 
Table F.3 Top 5 to $1 \%$ income shares and standard errors within parentheses

\begin{tabular}{|c|c|c|c|c|c|c|c|c|c|c|c|}
\hline Data set & SPI & HBAI-SPI & HBAI & FRS & $\begin{array}{c}\text { HBAI- } \\
\text { SPI2 }\end{array}$ & $\begin{array}{c}\text { HBAI- } \\
\text { SPI2 }\end{array}$ & $\begin{array}{l}\text { HBAI- } \\
\text { SPI2 }\end{array}$ & $\begin{array}{l}\text { HBAI- } \\
\text { SPI2 }\end{array}$ & $\begin{array}{l}\text { HBAI- } \\
\text { SPI2 }\end{array}$ & HBAI-SPI2 & HBAI-SPI2 \\
\hline $\begin{array}{l}\text { Income } \\
\text { definition }\end{array}$ & $\begin{array}{c}\text { Gross } \\
\text { income }\end{array}$ & $\begin{array}{c}\text { Gross } \\
\text { income }\end{array}$ & $\begin{array}{c}\text { Gross } \\
\text { income }\end{array}$ & $\begin{array}{c}\text { Gross } \\
\text { income }\end{array}$ & $\begin{array}{c}\text { Gross } \\
\text { income }\end{array}$ & $\begin{array}{c}\text { Gross } \\
\text { income }\end{array}$ & $\begin{array}{l}\text { Market } \\
\text { income }\end{array}$ & $\begin{array}{c}\text { Gross } \\
\text { income }\end{array}$ & $\begin{array}{l}\text { Market } \\
\text { income }\end{array}$ & $\begin{array}{c}\text { Gross } \\
\text { income }\end{array}$ & $\begin{array}{c}\text { Equivalised } \\
\text { gross } \\
\text { income }\end{array}$ \\
\hline Unit & Individual & Individual & Individual & Individual & Individual & Individual & Individual & Family & Family & Household & Household \\
\hline $\begin{array}{l}\text { Population } \\
\text { control }\end{array}$ & WTID & HBAI & HBAI & HBAI & HBAI & WTID & HBAI & HBAI & HBAI & HBAI & HBAI \\
\hline \multirow[t]{2}{*}{$\begin{array}{l}\text { Income } \\
\text { control }\end{array}$} & WTID & HBAI-SPI & HBAI & FRS & $\begin{array}{c}\text { HBAI- } \\
\text { SPI2 }\end{array}$ & WTID & $\begin{array}{c}\text { HBAI- } \\
\text { SPI2 }\end{array}$ & $\begin{array}{l}\text { HBAI- } \\
\text { SPI2 }\end{array}$ & $\begin{array}{l}\text { HBAI- } \\
\text { SPI2 }\end{array}$ & HBAI-SPI2 & HBAI-SPI2 \\
\hline & $(1)$ & $(2)$ & (3) & (4) & $(5)$ & (6) & $(7)$ & $(8)$ & $(9)$ & $(10)$ & $(11)$ \\
\hline $1994 / 95$ & & $\begin{array}{l}13.65 \\
(0.10)\end{array}$ & $\begin{array}{l}13.73 \\
(0.10)\end{array}$ & $\begin{array}{l}13.76 \\
(0.10)\end{array}$ & & & & & & & \\
\hline 1995/96 & $\begin{array}{l}15.05 \\
(2.29)\end{array}$ & $\begin{array}{l}13.41 \\
(0.10)\end{array}$ & $\begin{array}{l}13.56 \\
(0.10)\end{array}$ & $\begin{array}{l}13.54 \\
(0.10)\end{array}$ & $\begin{array}{l}13.68 \\
(0.11)\end{array}$ & $\begin{array}{l}15.04 \\
(0.57)\end{array}$ & $\begin{array}{l}16.19 \\
(0.13)\end{array}$ & $\begin{array}{l}13.35 \\
(0.11)\end{array}$ & $\begin{array}{l}15.70 \\
(0.13)\end{array}$ & $\begin{array}{l}12.27 \\
(0.11)\end{array}$ & $\begin{array}{l}11.77 \\
(0.11)\end{array}$ \\
\hline 1996/97 & $\begin{array}{l}14.95 \\
(2.15)\end{array}$ & $\begin{array}{l}13.38 \\
(0.09)\end{array}$ & $\begin{array}{l}13.51 \\
(0.10)\end{array}$ & $\begin{array}{l}13.54 \\
(0.10)\end{array}$ & $\begin{array}{l}13.43 \\
(0.11)\end{array}$ & $\begin{array}{l}14.94 \\
(0.45)\end{array}$ & $\begin{array}{l}15.79 \\
(0.13)\end{array}$ & $\begin{array}{l}13.18 \\
(0.12)\end{array}$ & $\begin{array}{l}15.38 \\
(0.14)\end{array}$ & $\begin{array}{l}12.26 \\
(0.12)\end{array}$ & $\begin{array}{l}11.69 \\
(0.12)\end{array}$ \\
\hline 1997/98 & $\begin{array}{l}14.71 \\
(1.83)\end{array}$ & $\begin{array}{l}13.45 \\
(0.11)\end{array}$ & $\begin{array}{l}13.66 \\
(0.11)\end{array}$ & $\begin{array}{l}13.66 \\
(0.11)\end{array}$ & $\begin{array}{l}13.55 \\
(0.13)\end{array}$ & $\begin{array}{l}14.70 \\
(0.41)\end{array}$ & $\begin{array}{l}15.79 \\
(0.15)\end{array}$ & $\begin{array}{l}13.26 \\
(0.13)\end{array}$ & $\begin{array}{l}15.37 \\
(0.16)\end{array}$ & $\begin{array}{l}12.32 \\
(0.14)\end{array}$ & $\begin{array}{l}11.67 \\
(0.13)\end{array}$ \\
\hline 1998/99 & $\begin{array}{l}14.90 \\
(1.64)\end{array}$ & $\begin{array}{l}13.74 \\
(0.12)\end{array}$ & $\begin{array}{l}13.88 \\
(0.12)\end{array}$ & $\begin{array}{l}13.88 \\
(0.12)\end{array}$ & $\begin{array}{l}13.72 \\
(0.13)\end{array}$ & $\begin{array}{l}14.89 \\
(0.41)\end{array}$ & $\begin{array}{l}15.93 \\
(0.16)\end{array}$ & $\begin{array}{l}13.49 \\
(0.14)\end{array}$ & $\begin{array}{l}15.59 \\
(0.17)\end{array}$ & $\begin{array}{l}12.66 \\
(0.15)\end{array}$ & $\begin{array}{l}11.99 \\
(0.13)\end{array}$ \\
\hline 1999/00 & $\begin{array}{l}15.55 \\
(1.72)\end{array}$ & $\begin{array}{l}13.40 \\
(0.12)\end{array}$ & $\begin{array}{l}13.57 \\
(0.11)\end{array}$ & $\begin{array}{l}13.54 \\
(0.11)\end{array}$ & $\begin{array}{l}13.89 \\
(0.13)\end{array}$ & $\begin{array}{l}15.54 \\
(0.47)\end{array}$ & $\begin{array}{l}16.10 \\
(0.15)\end{array}$ & $\begin{array}{l}13.61 \\
(0.14)\end{array}$ & $\begin{array}{l}15.69 \\
(0.16)\end{array}$ & $\begin{array}{l}12.74 \\
(0.14)\end{array}$ & $\begin{array}{l}12.00 \\
(0.13)\end{array}$ \\
\hline 2000/01 & $\begin{array}{l}15.32 \\
(1.57)\end{array}$ & $\begin{array}{l}13.66 \\
(0.13)\end{array}$ & $\begin{array}{l}13.57 \\
(0.16)\end{array}$ & $\begin{array}{l}13.63 \\
(0.16)\end{array}$ & $\begin{array}{l}13.99 \\
(0.14)\end{array}$ & $\begin{array}{l}15.31 \\
(0.45)\end{array}$ & $\begin{array}{l}16.16 \\
(0.16)\end{array}$ & $\begin{array}{l}13.60 \\
(0.15)\end{array}$ & $\begin{array}{l}15.60 \\
(0.17)\end{array}$ & $\begin{array}{l}12.79 \\
(0.14)\end{array}$ & $\begin{array}{l}12.16 \\
(0.15)\end{array}$ \\
\hline 2001/02 & $\begin{array}{l}15.62 \\
(1.53)\end{array}$ & $\begin{array}{l}13.59 \\
(0.12)\end{array}$ & $\begin{array}{l}13.53 \\
(0.23)\end{array}$ & $\begin{array}{l}13.36 \\
(0.33)\end{array}$ & $\begin{array}{l}14.01 \\
(0.13)\end{array}$ & $\begin{array}{l}15.61 \\
(0.49)\end{array}$ & $\begin{array}{l}16.17 \\
(0.15)\end{array}$ & $\begin{array}{l}13.72 \\
(0.14)\end{array}$ & $\begin{array}{l}15.76 \\
(0.16)\end{array}$ & $\begin{array}{l}12.88 \\
(0.14)\end{array}$ & $\begin{array}{l}12.20 \\
(0.14)\end{array}$ \\
\hline $2002 / 03$ & $\begin{array}{l}15.58 \\
(1.48)\end{array}$ & $\begin{array}{l}13.53 \\
(0.12)\end{array}$ & $\begin{array}{l}13.76 \\
(0.10)\end{array}$ & $\begin{array}{l}13.78 \\
(0.11)\end{array}$ & $\begin{array}{l}13.93 \\
(0.13)\end{array}$ & $\begin{array}{l}15.56 \\
(0.23)\end{array}$ & $\begin{array}{l}16.17 \\
(0.15)\end{array}$ & $\begin{array}{l}13.70 \\
(0.13)\end{array}$ & $\begin{array}{l}15.81 \\
(0.15)\end{array}$ & $\begin{array}{l}12.66 \\
(0.13)\end{array}$ & $\begin{array}{l}11.99 \\
(0.13)\end{array}$ \\
\hline 2003/04 & $\begin{array}{l}15.65 \\
(1.61)\end{array}$ & $\begin{array}{l}13.42 \\
(0.11)\end{array}$ & $\begin{array}{l}13.56 \\
(0.10)\end{array}$ & $\begin{array}{l}13.51 \\
(0.11)\end{array}$ & $\begin{array}{l}13.63 \\
(0.13)\end{array}$ & $\begin{array}{l}15.64 \\
(0.26)\end{array}$ & $\begin{array}{l}15.91 \\
(0.15)\end{array}$ & $\begin{array}{l}13.45 \\
(0.13)\end{array}$ & $\begin{array}{l}15.61 \\
(0.16)\end{array}$ & $\begin{array}{l}12.47 \\
(0.13)\end{array}$ & $\begin{array}{l}12.03 \\
(0.14)\end{array}$ \\
\hline
\end{tabular}

APPENDICES - 13 


\begin{tabular}{|c|c|c|c|c|c|c|c|c|c|c|c|}
\hline \multirow[t]{2}{*}{ 2004/05 } & 15.27 & 13.54 & 13.67 & 13.61 & 13.65 & 15.26 & 15.88 & 13.53 & 15.65 & 12.54 & 11.99 \\
\hline & (1.50) & $(0.12)$ & $(0.11)$ & $(0.12)$ & $(0.13)$ & $(0.25)$ & $(0.16)$ & (0.14) & $(0.17)$ & $(0.15)$ & $(0.15)$ \\
\hline \multirow[t]{2}{*}{$2005 / 06$} & 15.33 & 13.61 & 13.37 & 13.66 & 14.09 & 15.32 & 16.35 & 14.09 & 16.26 & 13.07 & 12.42 \\
\hline & (1.40) & $(0.12)$ & $(0.24)$ & $(0.11)$ & $(0.14)$ & $(0.22)$ & $(0.16)$ & (0.16) & $(0.18)$ & $(0.15)$ & $(0.15)$ \\
\hline \multirow[t]{2}{*}{ 2006/07 } & 15.27 & 13.59 & 13.54 & & 14.14 & 15.26 & 16.28 & 14.07 & 16.12 & 13.03 & 12.53 \\
\hline & (1.36) & $(0.14)$ & $(0.12)$ & $(0.12)$ & $(0.16)$ & $(0.23)$ & (0.19) & (0.18) & $(0.21)$ & (0.17) & $(0.18)$ \\
\hline \multirow[t]{2}{*}{$2007 / 08$} & 15.33 & 13.88 & 13.83 & 13.94 & 14.24 & 15.32 & 16.39 & 14.12 & 16.18 & 13.19 & 12.42 \\
\hline & (1.28) & $(0.16)$ & $(0.12)$ & $(0.12)$ & $(0.17)$ & $(0.22)$ & $(0.20)$ & (0.19) & $(0.22)$ & (0.19) & $(0.18)$ \\
\hline \multirow[t]{2}{*}{ 2008/09 } & & 13.82 & 13.51 & 13.60 & & & & & & & \\
\hline & & $(0.15)$ & $(0.35)$ & $(0.36)$ & & & & & & & \\
\hline \multirow[t]{2}{*}{ 2009/10 } & 14.59 & 13.96 & 13.91 & 14.06 & 13.71 & 14.57 & 16.09 & 13.72 & 16.02 & 12.75 & 12.06 \\
\hline & $(0.68)$ & $(0.16)$ & $(0.13)$ & $(0.13)$ & $(0.17)$ & $(0.21)$ & $(0.21)$ & (0.18) & $(0.22)$ & $(0.17)$ & $(0.16)$ \\
\hline \multirow[t]{2}{*}{ 2010/11 } & 14.16 & 13.97 & 13.82 & 14.08 & 13.80 & 14.15 & 16.33 & 13.82 & 16.27 & 12.68 & 11.88 \\
\hline & $(0.74)$ & $(0.14)$ & $(0.12)$ & $(0.12)$ & $(0.14)$ & $(0.21)$ & $(0.17)$ & (0.15) & $(0.19)$ & $(0.15)$ & $(0.14)$ \\
\hline \multirow[t]{2}{*}{ 2011/12 } & & 13.98 & 14.05 & 14.38 & & & & & & & \\
\hline & & $(0.18)$ & $(0.16)$ & $(0.17)$ & & & & & & & \\
\hline \multirow[t]{2}{*}{ 2012/13 } & & 13.86 & 13.75 & 14.09 & & & & & & & \\
\hline & & $(0.18)$ & $(0.14)$ & $(0.16)$ & & & & & & & \\
\hline
\end{tabular}

Source: Authors' calculations based on HBAI, FRS, SPI and WTID data. Household income is equivalised using the modified-OECD scale. The individual is the unit of analysis.

Estimates are based on the full population. The definition of the 'family' is the 'benefit unit' (see Department for Work and Pensions 2015) 
Table F.4 Top 10 to 5\% income shares and standard errors within parentheses

\begin{tabular}{|c|c|c|c|c|c|c|c|c|c|c|c|}
\hline Data set & SPI & HBAI-SPI & HBAI & FRS & $\begin{array}{c}\text { HBAI- } \\
\text { SPI2 }\end{array}$ & $\begin{array}{c}\text { HBAI- } \\
\text { SPI2 }\end{array}$ & $\begin{array}{c}\text { HBAI- } \\
\text { SPI2 }\end{array}$ & $\begin{array}{l}\text { HBAI- } \\
\text { SPI2 }\end{array}$ & $\begin{array}{l}\text { HBAI- } \\
\text { SPI2 }\end{array}$ & HBAI-SPI2 & HBAI-SPI2 \\
\hline $\begin{array}{l}\text { Income } \\
\text { definition }\end{array}$ & $\begin{array}{c}\text { Gross } \\
\text { income }\end{array}$ & $\begin{array}{c}\text { Gross } \\
\text { income }\end{array}$ & $\begin{array}{c}\text { Gross } \\
\text { income }\end{array}$ & $\begin{array}{c}\text { Gross } \\
\text { income }\end{array}$ & $\begin{array}{c}\text { Gross } \\
\text { income }\end{array}$ & $\begin{array}{c}\text { Gross } \\
\text { income }\end{array}$ & $\begin{array}{l}\text { Market } \\
\text { income }\end{array}$ & $\begin{array}{c}\text { Gross } \\
\text { income }\end{array}$ & $\begin{array}{l}\text { Market } \\
\text { income }\end{array}$ & $\begin{array}{c}\text { Gross } \\
\text { income }\end{array}$ & $\begin{array}{c}\text { Equivalised } \\
\text { gross } \\
\text { income }\end{array}$ \\
\hline Unit & Individual & Individual & Individual & Individual & Individual & Individual & Individual & Family & Family & Household & Household \\
\hline $\begin{array}{l}\text { Population } \\
\text { control }\end{array}$ & WTID & HBAI & HBAI & HBAI & HBAI & WTID & HBAI & HBAI & HBAI & HBAI & HBAI \\
\hline \multirow[t]{2}{*}{$\begin{array}{l}\text { Income } \\
\text { control }\end{array}$} & WTID & HBAI-SPI & HBAI & FRS & $\begin{array}{c}\text { HBAI- } \\
\text { SPI2 }\end{array}$ & WTID & $\begin{array}{c}\text { HBAI- } \\
\text { SPI2 }\end{array}$ & $\begin{array}{c}\text { HBAI- } \\
\text { SPI2 }\end{array}$ & $\begin{array}{c}\text { HBAI- } \\
\text { SPI2 }\end{array}$ & HBAI-SPI2 & HBAI-SPI2 \\
\hline & $(1)$ & $(2)$ & (3) & (4) & (5) & (6) & $(7)$ & $(8)$ & $(9)$ & $(10)$ & (11) \\
\hline $1994 / 95$ & & $\begin{array}{l}11.80 \\
(0.06)\end{array}$ & $\begin{array}{l}11.88 \\
(0.06)\end{array}$ & $\begin{array}{l}11.84 \\
(0.06)\end{array}$ & & & & & & & \\
\hline $1995 / 96$ & $\begin{array}{l}12.72 \\
(2.06)\end{array}$ & $\begin{array}{l}11.62 \\
(0.06)\end{array}$ & $\begin{array}{l}11.78 \\
(0.05)\end{array}$ & $\begin{array}{l}11.75 \\
(0.05)\end{array}$ & $\begin{array}{l}11.53 \\
(0.06)\end{array}$ & $\begin{array}{l}12.71 \\
(0.50)\end{array}$ & $\begin{array}{l}13.60 \\
(0.08)\end{array}$ & $\begin{array}{l}11.49 \\
(0.07)\end{array}$ & $\begin{array}{l}13.43 \\
(0.09)\end{array}$ & $\begin{array}{l}10.94 \\
(0.06)\end{array}$ & $\begin{array}{l}10.31 \\
(0.06)\end{array}$ \\
\hline 1996/97 & $\begin{array}{l}12.44 \\
(1.86)\end{array}$ & $\begin{array}{l}11.63 \\
(0.06)\end{array}$ & $\begin{array}{l}11.74 \\
(0.07)\end{array}$ & $\begin{array}{l}11.76 \\
(0.07)\end{array}$ & $\begin{array}{l}11.17 \\
(0.07)\end{array}$ & $\begin{array}{l}12.45 \\
(0.40)\end{array}$ & $\begin{array}{l}13.11 \\
(0.09)\end{array}$ & $\begin{array}{l}11.23 \\
(0.07)\end{array}$ & $\begin{array}{l}13.03 \\
(0.10)\end{array}$ & $\begin{array}{l}10.63 \\
(0.07)\end{array}$ & $\begin{array}{l}10.01 \\
(0.06)\end{array}$ \\
\hline $1997 / 98$ & $\begin{array}{l}12.15 \\
(1.68)\end{array}$ & $\begin{array}{l}11.43 \\
(0.07)\end{array}$ & $\begin{array}{l}11.65 \\
(0.06)\end{array}$ & $\begin{array}{l}11.65 \\
(0.06)\end{array}$ & $\begin{array}{l}11.17 \\
(0.08)\end{array}$ & $\begin{array}{l}12.15 \\
(0.37)\end{array}$ & $\begin{array}{l}12.97 \\
(0.10)\end{array}$ & $\begin{array}{l}11.17 \\
(0.08)\end{array}$ & $\begin{array}{l}12.86 \\
(0.11)\end{array}$ & $\begin{array}{l}10.61 \\
(0.08)\end{array}$ & $\begin{array}{l}10.00 \\
(0.07)\end{array}$ \\
\hline 1998/99 & $\begin{array}{l}12.06 \\
(1.44)\end{array}$ & $\begin{array}{l}11.40 \\
(0.08)\end{array}$ & $\begin{array}{l}11.56 \\
(0.08)\end{array}$ & $\begin{array}{l}11.56 \\
(0.08)\end{array}$ & $\begin{array}{l}11.09 \\
(0.08)\end{array}$ & $\begin{array}{l}12.06 \\
(0.36)\end{array}$ & $\begin{array}{l}12.83 \\
(0.10)\end{array}$ & $\begin{array}{l}11.22 \\
(0.09)\end{array}$ & $\begin{array}{l}12.88 \\
(0.11)\end{array}$ & $\begin{array}{l}10.74 \\
(0.08)\end{array}$ & $\begin{array}{l}10.10 \\
(0.08)\end{array}$ \\
\hline 1999/00 & $\begin{array}{l}12.49 \\
(1.52)\end{array}$ & $\begin{array}{l}11.26 \\
(0.08)\end{array}$ & $\begin{array}{l}11.52 \\
(0.06)\end{array}$ & $\begin{array}{l}11.52 \\
(0.06)\end{array}$ & $\begin{array}{l}11.12 \\
(0.08)\end{array}$ & $\begin{array}{l}12.48 \\
(0.40)\end{array}$ & $\begin{array}{l}12.85 \\
(0.11)\end{array}$ & $\begin{array}{l}11.17 \\
(0.08)\end{array}$ & $\begin{array}{l}12.79 \\
(0.11)\end{array}$ & $\begin{array}{l}10.78 \\
(0.08)\end{array}$ & $\begin{array}{l}10.18 \\
(0.08)\end{array}$ \\
\hline $2000 / 01$ & $\begin{array}{l}12.15 \\
(1.36)\end{array}$ & $\begin{array}{l}11.07 \\
(0.08)\end{array}$ & $\begin{array}{l}11.09 \\
(0.12)\end{array}$ & $\begin{array}{l}11.11 \\
(0.12)\end{array}$ & $\begin{array}{l}11.06 \\
(0.09)\end{array}$ & $\begin{array}{l}12.14 \\
(0.37)\end{array}$ & $\begin{array}{l}12.72 \\
(0.11)\end{array}$ & $\begin{array}{l}11.21 \\
(0.09)\end{array}$ & $\begin{array}{l}12.77 \\
(0.12)\end{array}$ & $\begin{array}{l}10.73 \\
(0.09)\end{array}$ & $\begin{array}{l}10.02 \\
(0.09)\end{array}$ \\
\hline 2001/02 & $\begin{array}{l}12.44 \\
(1.33)\end{array}$ & $\begin{array}{l}11.19 \\
(0.09)\end{array}$ & $\begin{array}{l}11.27 \\
(0.18)\end{array}$ & $\begin{array}{l}11.26 \\
(0.18)\end{array}$ & $\begin{array}{l}11.13 \\
(0.08)\end{array}$ & $\begin{array}{l}12.43 \\
(0.41)\end{array}$ & $\begin{array}{l}12.80 \\
(0.10)\end{array}$ & $\begin{array}{l}11.22 \\
(0.08)\end{array}$ & $\begin{array}{l}12.78 \\
(0.11)\end{array}$ & $\begin{array}{l}10.77 \\
(0.08)\end{array}$ & $\begin{array}{l}10.16 \\
(0.08)\end{array}$ \\
\hline $2002 / 03$ & $\begin{array}{l}12.44 \\
(1.28)\end{array}$ & $\begin{array}{l}11.21 \\
(0.09)\end{array}$ & $\begin{array}{l}11.55 \\
(0.06)\end{array}$ & $\begin{array}{l}11.52 \\
(0.06)\end{array}$ & $\begin{array}{l}11.12 \\
(0.08)\end{array}$ & $\begin{array}{l}12.43 \\
(0.18)\end{array}$ & $\begin{array}{l}12.85 \\
(0.10)\end{array}$ & $\begin{array}{l}11.24 \\
(0.08)\end{array}$ & $\begin{array}{l}12.88 \\
(0.10)\end{array}$ & $\begin{array}{l}10.76 \\
(0.08)\end{array}$ & $\begin{array}{l}10.14 \\
(0.07)\end{array}$ \\
\hline $2003 / 04$ & $\begin{array}{l}12.44 \\
(1.42)\end{array}$ & $\begin{array}{l}11.25 \\
(0.08)\end{array}$ & $\begin{array}{l}11.49 \\
(0.06)\end{array}$ & $\begin{array}{l}11.47 \\
(0.06)\end{array}$ & $\begin{array}{l}10.84 \\
(0.07)\end{array}$ & $\begin{array}{l}12.45 \\
(0.21)\end{array}$ & $\begin{array}{l}12.61 \\
(0.10)\end{array}$ & $\begin{array}{l}11.20 \\
(0.08)\end{array}$ & $\begin{array}{l}12.89 \\
(0.10)\end{array}$ & $\begin{array}{l}10.55 \\
(0.08)\end{array}$ & $\begin{array}{c}9.95 \\
(0.07)\end{array}$ \\
\hline
\end{tabular}




\begin{tabular}{|c|c|c|c|c|c|c|c|c|c|c|c|}
\hline \multirow[t]{2}{*}{ 2004/05 } & 12.29 & 11.12 & 11.41 & 11.36 & 10.97 & 12.28 & 12.72 & 11.13 & 12.77 & 10.62 & 9.95 \\
\hline & (1.36) & $(0.08)$ & $(0.06)$ & $(0.06)$ & $(0.08)$ & $(0.20)$ & $(0.10)$ & $(0.08)$ & $(0.11)$ & $(0.08)$ & $(0.08)$ \\
\hline \multirow[t]{2}{*}{$2005 / 06$} & 12.05 & 11.17 & 11.21 & 11.43 & 11.06 & 12.04 & 12.80 & 11.15 & 12.76 & 10.61 & 9.96 \\
\hline & (1.28) & $(0.08)$ & $(0.20)$ & $(0.06)$ & $(0.08)$ & (0.17) & $(0.11)$ & (0.09) & $(0.11)$ & $(0.08)$ & $(0.08)$ \\
\hline \multirow[t]{2}{*}{ 2006/07 } & 11.89 & 11.15 & 11.43 & 11.41 & 10.99 & 11.88 & 12.61 & 11.14 & 12.67 & 10.63 & 10.01 \\
\hline & $(1.24)$ & $(0.08)$ & $(0.07)$ & $(0.07)$ & $(0.10)$ & $(0.17)$ & (0.13) & $(0.11)$ & $(0.14)$ & $(0.11)$ & $(0.09)$ \\
\hline \multirow[t]{2}{*}{ 2007/08 } & 11.83 & 10.98 & 11.39 & 11.45 & 10.97 & 11.82 & 12.58 & 11.04 & 12.55 & 10.52 & 9.92 \\
\hline & (1.16) & (0.09) & $(0.06)$ & $(0.06)$ & $(0.11)$ & $(0.16)$ & $(0.15)$ & $(0.12)$ & $(0.16)$ & $(0.12)$ & $(0.10)$ \\
\hline \multirow[t]{2}{*}{ 2008/09 } & & 11.06 & 11.21 & 11.27 & & & & & & & \\
\hline & & $(0.10)$ & $(0.29)$ & $(0.29)$ & & & & & & & \\
\hline \multirow[t]{2}{*}{ 2009/10 } & 11.52 & 10.89 & 11.29 & 11.35 & 10.82 & 11.52 & 12.64 & 10.90 & 12.62 & 10.37 & 9.82 \\
\hline & $(0.62)$ & $(0.11)$ & $(0.08)$ & $(0.07)$ & $(0.12)$ & $(0.17)$ & $(0.16)$ & $(0.12)$ & $(0.17)$ & $(0.12)$ & $(0.11)$ \\
\hline \multirow[t]{2}{*}{ 2010/11 } & 11.36 & 11.07 & 11.28 & 11.42 & 11.05 & 11.35 & 13.02 & 11.22 & 13.08 & 10.60 & 9.92 \\
\hline & $(0.67)$ & $(0.08)$ & $(0.07)$ & $(0.06)$ & $(0.08)$ & $(0.16)$ & $(0.12)$ & $(0.10)$ & $(0.13)$ & (0.09) & $(0.08)$ \\
\hline \multirow[t]{2}{*}{ 2011/12 } & & 11.04 & 11.48 & 11.39 & & & & & & & \\
\hline & & $(0.11)$ & $(0.07)$ & $(0.08)$ & & & & & & & \\
\hline \multirow[t]{2}{*}{ 2012/13 } & & 10.92 & 11.27 & 11.22 & & & & & & & \\
\hline & & $(0.10)$ & $(0.08)$ & $(0.07)$ & & & & & & & \\
\hline
\end{tabular}

Source: Authors' calculations based on HBAI, FRS, SPI and WTID data. Household income is equivalised using the modified-OECD scale. The individual is the unit of analysis.

Estimates are based on the full population. The definition of the 'family' is the 'benefit unit' (see Department for Work and Pensions 2015) 
Appendix G. Inequality indices and standard errors

Table G.1 Gini coefficient and standard errors within parentheses

\begin{tabular}{|c|c|c|c|c|c|}
\hline Data set & $\begin{array}{c}\text { HBAI- } \\
\text { SPI }\end{array}$ & $\begin{array}{c}\text { HBAI- } \\
\text { SPI }\end{array}$ & $\begin{array}{c}\text { HBAI- } \\
\text { SPI }\end{array}$ & $\begin{array}{c}\text { HBAI- } \\
\text { SPI2 }\end{array}$ & $\begin{array}{c}\text { HBAI- } \\
\text { SPI2 }\end{array}$ \\
\hline $\begin{array}{l}\text { Income } \\
\text { definition }\end{array}$ & $\begin{array}{l}\text { Gross } \\
\text { income }\end{array}$ & $\begin{array}{l}\text { Market } \\
\text { income }\end{array}$ & $\begin{array}{c}\text { Net } \\
\text { income }\end{array}$ & $\begin{array}{l}\text { Gross } \\
\text { income }\end{array}$ & $\begin{array}{l}\text { Market } \\
\text { income }\end{array}$ \\
\hline & (1) & (2) & (3) & (4) & (5) \\
\hline $1994 / 95$ & $\begin{array}{l}0.372 \\
(0.00)\end{array}$ & $\begin{array}{l}0.512 \\
(0.00)\end{array}$ & $\begin{array}{l}0.332 \\
(0.00)\end{array}$ & & \\
\hline $1995 / 96$ & $\begin{array}{l}0.375 \\
(0.00)\end{array}$ & $\begin{array}{l}0.516 \\
(0.00)\end{array}$ & $\begin{array}{l}0.333 \\
(0.00)\end{array}$ & $\begin{array}{l}0.380 \\
(0.00)\end{array}$ & $\begin{array}{l}0.521 \\
(0.00)\end{array}$ \\
\hline 1996/97 & $\begin{array}{l}0.373 \\
(0.00)\end{array}$ & $\begin{array}{l}0.510 \\
(0.00)\end{array}$ & $\begin{array}{l}0.333 \\
(0.00)\end{array}$ & $\begin{array}{l}0.386 \\
(0.00)\end{array}$ & $\begin{array}{l}0.522 \\
(0.00)\end{array}$ \\
\hline $1997 / 98$ & $\begin{array}{l}0.383 \\
(0.00)\end{array}$ & $\begin{array}{l}0.512 \\
(0.00)\end{array}$ & $\begin{array}{l}0.340 \\
(0.00)\end{array}$ & $\begin{array}{l}0.388 \\
(0.00)\end{array}$ & $\begin{array}{l}0.517 \\
(0.00)\end{array}$ \\
\hline 1998/99 & $\begin{array}{l}0.389 \\
(0.01)\end{array}$ & $\begin{array}{l}0.517 \\
(0.00)\end{array}$ & $\begin{array}{l}0.348 \\
(0.00)\end{array}$ & $\begin{array}{l}0.396 \\
(0.00)\end{array}$ & $\begin{array}{l}0.523 \\
(0.00)\end{array}$ \\
\hline $1999 / 00$ & $\begin{array}{l}0.389 \\
(0.00)\end{array}$ & $\begin{array}{l}0.517 \\
(0.00)\end{array}$ & $\begin{array}{l}0.346 \\
(0.00)\end{array}$ & $\begin{array}{l}0.400 \\
(0.00)\end{array}$ & $\begin{array}{l}0.527 \\
(0.00)\end{array}$ \\
\hline $2000 / 01$ & $\begin{array}{l}0.395 \\
(0.00)\end{array}$ & $\begin{array}{l}0.519 \\
(0.00)\end{array}$ & $\begin{array}{l}0.353 \\
(0.00)\end{array}$ & $\begin{array}{l}0.403 \\
(0.00)\end{array}$ & $\begin{array}{l}0.526 \\
(0.00)\end{array}$ \\
\hline $2001 / 02$ & $\begin{array}{l}0.394 \\
(0.01)\end{array}$ & $\begin{array}{l}0.518 \\
(0.00)\end{array}$ & $\begin{array}{l}0.349 \\
(0.00)\end{array}$ & $\begin{array}{l}0.400 \\
(0.00)\end{array}$ & $\begin{array}{l}0.523 \\
(0.00)\end{array}$ \\
\hline $2002 / 03$ & $\begin{array}{l}0.388 \\
(0.01)\end{array}$ & $\begin{array}{l}0.514 \\
(0.00)\end{array}$ & $\begin{array}{l}0.343 \\
(0.00)\end{array}$ & $\begin{array}{l}0.391 \\
(0.00)\end{array}$ & $\begin{array}{l}0.517 \\
(0.00)\end{array}$ \\
\hline $2003 / 04$ & $\begin{array}{l}0.382 \\
(0.00)\end{array}$ & $\begin{array}{l}0.512 \\
(0.00)\end{array}$ & $\begin{array}{l}0.339 \\
(0.00)\end{array}$ & $\begin{array}{l}0.388 \\
(0.00)\end{array}$ & $\begin{array}{l}0.517 \\
(0.00)\end{array}$ \\
\hline $2004 / 05$ & $\begin{array}{l}0.384 \\
(0.00)\end{array}$ & $\begin{array}{l}0.513 \\
(0.00)\end{array}$ & $\begin{array}{l}0.339 \\
(0.00)\end{array}$ & $\begin{array}{l}0.390 \\
(0.00)\end{array}$ & $\begin{array}{l}0.518 \\
(0.00)\end{array}$ \\
\hline $2005 / 06$ & $\begin{array}{l}0.387 \\
(0.00)\end{array}$ & $\begin{array}{l}0.516 \\
(0.00)\end{array}$ & $\begin{array}{l}0.345 \\
(0.00)\end{array}$ & $\begin{array}{l}0.407 \\
(0.00)\end{array}$ & $\begin{array}{l}0.534 \\
(0.00)\end{array}$ \\
\hline $2006 / 07$ & $\begin{array}{l}0.392 \\
(0.01)\end{array}$ & $\begin{array}{l}0.516 \\
(0.00)\end{array}$ & $\begin{array}{l}0.350 \\
(0.00)\end{array}$ & $\begin{array}{l}0.414 \\
(0.01)\end{array}$ & $\begin{array}{l}0.536 \\
(0.01)\end{array}$ \\
\hline $2007 / 08$ & $\begin{array}{l}0.399 \\
(0.01)\end{array}$ & $\begin{array}{l}0.523 \\
(0.01)\end{array}$ & $\begin{array}{l}0.357 \\
(0.00)\end{array}$ & $\begin{array}{l}0.419 \\
(0.01)\end{array}$ & $\begin{array}{l}0.540 \\
(0.01)\end{array}$ \\
\hline 2008/09 & $\begin{array}{l}0.398 \\
(0.01)\end{array}$ & $\begin{array}{l}0.524 \\
(0.01)\end{array}$ & $\begin{array}{l}0.355 \\
(0.00)\end{array}$ & & \\
\hline $2009 / 10$ & $\begin{array}{l}0.404 \\
(0.01)\end{array}$ & $\begin{array}{l}0.538 \\
(0.01)\end{array}$ & $\begin{array}{l}0.356 \\
(0.01)\end{array}$ & $\begin{array}{l}0.413 \\
(0.01)\end{array}$ & $\begin{array}{l}0.547 \\
(0.01)\end{array}$ \\
\hline $2010 / 11$ & $\begin{array}{l}0.386 \\
(0.00)\end{array}$ & $\begin{array}{l}0.525 \\
(0.00)\end{array}$ & $\begin{array}{l}0.337 \\
(0.00)\end{array}$ & $\begin{array}{l}0.392 \\
(0.01)\end{array}$ & $\begin{array}{l}0.531 \\
(0.01)\end{array}$ \\
\hline $2011 / 12$ & $\begin{array}{l}0.392 \\
(0.01)\end{array}$ & $\begin{array}{l}0.528 \\
(0.01)\end{array}$ & $\begin{array}{l}0.340 \\
(0.01)\end{array}$ & & \\
\hline $2012 / 13$ & $\begin{array}{l}0.389 \\
(0.01)\end{array}$ & $\begin{array}{l}0.527 \\
(0.01)\end{array}$ & $\begin{array}{l}0.335 \\
(0.01)\end{array}$ & & \\
\hline
\end{tabular}

Notes: Northern Ireland is included in the FRS and hence HBAI data only from 2002/03 onwards.

Source: Authors' calculations based on HBAI, FRS, SPI and WTID data. Household income is equivalised using the modified-OECD scale. The individual is the unit of analysis. Estimates are based on the full population. 
Table G.2 Mean logarithmic deviation (MLD) and standard errors within parentheses

\begin{tabular}{|c|c|c|c|c|c|}
\hline Data set & $\begin{array}{l}\text { HBAI- } \\
\text { SPI }\end{array}$ & $\begin{array}{l}\text { HBAI- } \\
\text { SPI }\end{array}$ & $\begin{array}{l}\text { HBAI- } \\
\text { SPI }\end{array}$ & $\begin{array}{l}\text { HBAI- } \\
\text { SPI2 }\end{array}$ & $\begin{array}{l}\text { HBAI- } \\
\text { SPI2 }\end{array}$ \\
\hline $\begin{array}{l}\text { Income } \\
\text { definition }\end{array}$ & $\begin{array}{l}\text { Gross } \\
\text { income }\end{array}$ & $\begin{array}{l}\text { Market } \\
\text { income }\end{array}$ & $\begin{array}{c}\text { Net } \\
\text { income }\end{array}$ & $\begin{array}{l}\text { Gross } \\
\text { income }\end{array}$ & $\begin{array}{l}\text { Market } \\
\text { income }\end{array}$ \\
\hline & (1) & (2) & (3) & (4) & (5) \\
\hline $1994 / 95$ & $\begin{array}{l}0.235 \\
(0.00)\end{array}$ & $\begin{array}{l}0.660 \\
(0.01)\end{array}$ & $\begin{array}{l}0.186 \\
(0.00)\end{array}$ & & \\
\hline 1995/96 & $\begin{array}{l}0.239 \\
(0.00)\end{array}$ & $\begin{array}{l}0.639 \\
(0.01)\end{array}$ & $\begin{array}{l}0.186 \\
(0.00)\end{array}$ & $\begin{array}{l}0.245 \\
(0.00)\end{array}$ & $\begin{array}{l}0.647 \\
(0.01)\end{array}$ \\
\hline 1996/97 & $\begin{array}{l}0.238 \\
(0.00)\end{array}$ & $\begin{array}{l}0.652 \\
(0.01)\end{array}$ & $\begin{array}{l}0.187 \\
(0.00)\end{array}$ & $\begin{array}{l}0.255 \\
(0.01)\end{array}$ & $\begin{array}{l}0.669 \\
(0.01)\end{array}$ \\
\hline $1997 / 98$ & $\begin{array}{l}0.252 \\
(0.01)\end{array}$ & $\begin{array}{l}0.641 \\
(0.01)\end{array}$ & $\begin{array}{l}0.196 \\
(0.00)\end{array}$ & $\begin{array}{l}0.259 \\
(0.01)\end{array}$ & $\begin{array}{l}0.645 \\
(0.01)\end{array}$ \\
\hline 1998/99 & $\begin{array}{l}0.260 \\
(0.01)\end{array}$ & $\begin{array}{l}0.653 \\
(0.01)\end{array}$ & $\begin{array}{l}0.205 \\
(0.01)\end{array}$ & $\begin{array}{l}0.269 \\
(0.01)\end{array}$ & $\begin{array}{l}0.661 \\
(0.01)\end{array}$ \\
\hline 1999/00 & $\begin{array}{l}0.260 \\
(0.01)\end{array}$ & $\begin{array}{l}0.653 \\
(0.01)\end{array}$ & $\begin{array}{l}0.203 \\
(0.01)\end{array}$ & $\begin{array}{l}0.275 \\
(0.01)\end{array}$ & $\begin{array}{l}0.669 \\
(0.01)\end{array}$ \\
\hline 2000/01 & $\begin{array}{l}0.270 \\
(0.01)\end{array}$ & $\begin{array}{l}0.685 \\
(0.01)\end{array}$ & $\begin{array}{l}0.211 \\
(0.01)\end{array}$ & $\begin{array}{l}0.280 \\
(0.01)\end{array}$ & $\begin{array}{l}0.697 \\
(0.01)\end{array}$ \\
\hline $2001 / 02$ & $\begin{array}{l}0.268 \\
(0.01)\end{array}$ & $\begin{array}{l}0.671 \\
(0.01)\end{array}$ & $\begin{array}{l}0.208 \\
(0.01)\end{array}$ & $\begin{array}{l}0.275 \\
(0.01)\end{array}$ & $\begin{array}{l}0.680 \\
(0.01)\end{array}$ \\
\hline $2002 / 03$ & $\begin{array}{l}0.261 \\
(0.01)\end{array}$ & $\begin{array}{l}0.665 \\
(0.01)\end{array}$ & $\begin{array}{l}0.201 \\
(0.01)\end{array}$ & $\begin{array}{l}0.264 \\
(0.01)\end{array}$ & $\begin{array}{l}0.668 \\
(0.01)\end{array}$ \\
\hline $2003 / 04$ & $\begin{array}{l}0.253 \\
(0.01)\end{array}$ & $\begin{array}{l}0.656 \\
(0.01)\end{array}$ & $\begin{array}{l}0.196 \\
(0.01)\end{array}$ & $\begin{array}{l}0.260 \\
(0.01)\end{array}$ & $\begin{array}{l}0.663 \\
(0.01)\end{array}$ \\
\hline $2004 / 05$ & $\begin{array}{l}0.254 \\
(0.01)\end{array}$ & $\begin{array}{l}0.649 \\
(0.01)\end{array}$ & $\begin{array}{l}0.195 \\
(0.00)\end{array}$ & $\begin{array}{l}0.261 \\
(0.01)\end{array}$ & $\begin{array}{l}0.658 \\
(0.01)\end{array}$ \\
\hline $2005 / 06$ & $\begin{array}{l}0.259 \\
(0.01)\end{array}$ & $\begin{array}{l}0.653 \\
(0.01)\end{array}$ & $\begin{array}{l}0.203 \\
(0.01)\end{array}$ & $\begin{array}{l}0.286 \\
(0.01)\end{array}$ & $\begin{array}{l}0.683 \\
(0.01)\end{array}$ \\
\hline $2006 / 07$ & $\begin{array}{l}0.268 \\
(0.01)\end{array}$ & $\begin{array}{l}0.639 \\
(0.01)\end{array}$ & $\begin{array}{l}0.211 \\
(0.01)\end{array}$ & $\begin{array}{l}0.299 \\
(0.01)\end{array}$ & $\begin{array}{l}0.675 \\
(0.01)\end{array}$ \\
\hline $2007 / 08$ & $\begin{array}{l}0.277 \\
(0.01)\end{array}$ & $\begin{array}{l}0.651 \\
(0.01)\end{array}$ & $\begin{array}{l}0.217 \\
(0.01)\end{array}$ & $\begin{array}{l}0.305 \\
(0.01)\end{array}$ & $\begin{array}{l}0.684 \\
(0.01)\end{array}$ \\
\hline 2008/09 & $\begin{array}{l}0.276 \\
(0.01)\end{array}$ & $\begin{array}{l}0.646 \\
(0.01)\end{array}$ & $\begin{array}{l}0.217 \\
(0.01)\end{array}$ & & \\
\hline $2009 / 10$ & $\begin{array}{l}0.283 \\
(0.01)\end{array}$ & $\begin{array}{l}0.675 \\
(0.01)\end{array}$ & $\begin{array}{l}0.217 \\
(0.01)\end{array}$ & $\begin{array}{l}0.297 \\
(0.01)\end{array}$ & $\begin{array}{l}0.691 \\
(0.01)\end{array}$ \\
\hline 2010/11 & $\begin{array}{l}0.256 \\
(0.01)\end{array}$ & $\begin{array}{l}0.640 \\
(0.01)\end{array}$ & $\begin{array}{l}0.194 \\
(0.00)\end{array}$ & $\begin{array}{l}0.265 \\
(0.01)\end{array}$ & $\begin{array}{l}0.654 \\
(0.01)\end{array}$ \\
\hline $2011 / 12$ & $\begin{array}{l}0.263 \\
(0.01)\end{array}$ & $\begin{array}{l}0.629 \\
(0.01)\end{array}$ & $\begin{array}{l}0.196 \\
(0.01)\end{array}$ & & \\
\hline $2012 / 13$ & $\begin{array}{l}0.261 \\
(0.01)\end{array}$ & $\begin{array}{l}0.622 \\
(0.01)\end{array}$ & $\begin{array}{l}0.193 \\
(0.01)\end{array}$ & & \\
\hline
\end{tabular}

Notes: Northern Ireland is included in the FRS and hence HBAI data only from 2002/03 onwards.

Source: Authors' calculations based on HBAI, FRS, SPI and WTID data. Household income is equivalised using the modified-OECD scale. The individual is the unit of analysis. Estimates are based on the full population. 
Table G.3 Theil index and standard errors within parentheses

\begin{tabular}{|c|c|c|c|c|c|}
\hline Data set & $\begin{array}{l}\text { HBAI- } \\
\text { SPI }\end{array}$ & $\begin{array}{l}\text { HBAI- } \\
\text { SPI }\end{array}$ & $\begin{array}{l}\text { HBAI- } \\
\text { SPI }\end{array}$ & $\begin{array}{l}\text { HBAI- } \\
\text { SPI2 }\end{array}$ & $\begin{array}{c}\text { HBAI- } \\
\text { SPI2 }\end{array}$ \\
\hline $\begin{array}{l}\text { Income } \\
\text { definition }\end{array}$ & $\begin{array}{l}\text { Gross } \\
\text { income }\end{array}$ & $\begin{array}{l}\text { Market } \\
\text { income }\end{array}$ & $\begin{array}{c}\text { Net } \\
\text { income }\end{array}$ & $\begin{array}{l}\text { Gross } \\
\text { income }\end{array}$ & $\begin{array}{l}\text { Market } \\
\text { income }\end{array}$ \\
\hline & $(1)$ & (2) & (3) & (4) & (5) \\
\hline $1994 / 95$ & $\begin{array}{l}0.257 \\
(0.01)\end{array}$ & $\begin{array}{l}0.417 \\
(0.01)\end{array}$ & $\begin{array}{l}0.202 \\
(0.00)\end{array}$ & & \\
\hline $1995 / 96$ & $\begin{array}{l}0.266 \\
(0.01)\end{array}$ & $\begin{array}{l}0.418 \\
(0.01)\end{array}$ & $\begin{array}{l}0.205 \\
(0.01)\end{array}$ & $\begin{array}{l}0.275 \\
(0.01)\end{array}$ & $\begin{array}{l}0.427 \\
(0.01)\end{array}$ \\
\hline 1996/97 & $\begin{array}{l}0.261 \\
(0.01)\end{array}$ & $\begin{array}{l}0.414 \\
(0.01)\end{array}$ & $\begin{array}{l}0.205 \\
(0.01)\end{array}$ & $\begin{array}{l}0.297 \\
(0.01)\end{array}$ & $\begin{array}{l}0.453 \\
(0.01)\end{array}$ \\
\hline $1997 / 98$ & $\begin{array}{l}0.289 \\
(0.01)\end{array}$ & $\begin{array}{l}0.435 \\
(0.01)\end{array}$ & $\begin{array}{l}0.222 \\
(0.01)\end{array}$ & $\begin{array}{l}0.303 \\
(0.01)\end{array}$ & $\begin{array}{l}0.449 \\
(0.01)\end{array}$ \\
\hline 1998/99 & $\begin{array}{l}0.303 \\
(0.02)\end{array}$ & $\begin{array}{l}0.450 \\
(0.02)\end{array}$ & $\begin{array}{l}0.238 \\
(0.01)\end{array}$ & $\begin{array}{l}0.321 \\
(0.01)\end{array}$ & $\begin{array}{l}0.469 \\
(0.01)\end{array}$ \\
\hline $1999 / 00$ & $\begin{array}{l}0.306 \\
(0.01)\end{array}$ & $\begin{array}{l}0.454 \\
(0.02)\end{array}$ & $\begin{array}{l}0.237 \\
(0.01)\end{array}$ & $\begin{array}{l}0.331 \\
(0.01)\end{array}$ & $\begin{array}{l}0.480 \\
(0.01)\end{array}$ \\
\hline $2000 / 01$ & $\begin{array}{l}0.322 \\
(0.01)\end{array}$ & $\begin{array}{l}0.475 \\
(0.01)\end{array}$ & $\begin{array}{l}0.251 \\
(0.01)\end{array}$ & $\begin{array}{l}0.341 \\
(0.01)\end{array}$ & $\begin{array}{l}0.494 \\
(0.02)\end{array}$ \\
\hline $2001 / 02$ & $\begin{array}{l}0.325 \\
(0.02)\end{array}$ & $\begin{array}{l}0.479 \\
(0.02)\end{array}$ & $\begin{array}{l}0.250 \\
(0.01)\end{array}$ & $\begin{array}{l}0.333 \\
(0.01)\end{array}$ & $\begin{array}{l}0.486 \\
(0.01)\end{array}$ \\
\hline $2002 / 03$ & $\begin{array}{l}0.312 \\
(0.01)\end{array}$ & $\begin{array}{l}0.469 \\
(0.02)\end{array}$ & $\begin{array}{l}0.239 \\
(0.01)\end{array}$ & $\begin{array}{l}0.312 \\
(0.01)\end{array}$ & $\begin{array}{l}0.467 \\
(0.01)\end{array}$ \\
\hline $2003 / 04$ & $\begin{array}{l}0.296 \\
(0.01)\end{array}$ & $\begin{array}{l}0.455 \\
(0.02)\end{array}$ & $\begin{array}{l}0.228 \\
(0.01)\end{array}$ & $\begin{array}{l}0.311 \\
(0.01)\end{array}$ & $\begin{array}{l}0.471 \\
(0.01)\end{array}$ \\
\hline $2004 / 05$ & $\begin{array}{l}0.299 \\
(0.01)\end{array}$ & $\begin{array}{l}0.457 \\
(0.01)\end{array}$ & $\begin{array}{l}0.229 \\
(0.01)\end{array}$ & $\begin{array}{l}0.317 \\
(0.01)\end{array}$ & $\begin{array}{l}0.476 \\
(0.01)\end{array}$ \\
\hline 2005/06 & $\begin{array}{l}0.305 \\
(0.01)\end{array}$ & $\begin{array}{l}0.464 \\
(0.01)\end{array}$ & $\begin{array}{l}0.238 \\
(0.01)\end{array}$ & $\begin{array}{l}0.356 \\
(0.01)\end{array}$ & $\begin{array}{l}0.519 \\
(0.02)\end{array}$ \\
\hline 2006/07 & $\begin{array}{l}0.316 \\
(0.01)\end{array}$ & $\begin{array}{l}0.467 \\
(0.02)\end{array}$ & $\begin{array}{l}0.247 \\
(0.01)\end{array}$ & $\begin{array}{l}0.384 \\
(0.02)\end{array}$ & $\begin{array}{l}0.540 \\
(0.02)\end{array}$ \\
\hline $2007 / 08$ & $\begin{array}{l}0.332 \\
(0.01)\end{array}$ & $\begin{array}{l}0.484 \\
(0.02)\end{array}$ & $\begin{array}{l}0.258 \\
(0.01)\end{array}$ & $\begin{array}{l}0.396 \\
(0.02)\end{array}$ & $\begin{array}{l}0.553 \\
(0.03)\end{array}$ \\
\hline 2008/09 & $\begin{array}{l}0.335 \\
(0.02)\end{array}$ & $\begin{array}{l}0.494 \\
(0.02)\end{array}$ & $\begin{array}{l}0.258 \\
(0.01)\end{array}$ & & \\
\hline 2009/10 & $\begin{array}{l}0.347 \\
(0.02)\end{array}$ & $\begin{array}{l}0.517 \\
(0.02)\end{array}$ & $\begin{array}{l}0.260 \\
(0.01)\end{array}$ & $\begin{array}{l}0.395 \\
(0.02)\end{array}$ & $\begin{array}{l}0.571 \\
(0.03)\end{array}$ \\
\hline 2010/11 & $\begin{array}{l}0.307 \\
(0.01)\end{array}$ & $\begin{array}{l}0.475 \\
(0.01)\end{array}$ & $\begin{array}{l}0.221 \\
(0.01)\end{array}$ & $\begin{array}{l}0.334 \\
(0.02)\end{array}$ & $\begin{array}{l}0.506 \\
(0.02)\end{array}$ \\
\hline $2011 / 12$ & $\begin{array}{l}0.327 \\
(0.02)\end{array}$ & $\begin{array}{l}0.494 \\
(0.02)\end{array}$ & $\begin{array}{l}0.230 \\
(0.01)\end{array}$ & & \\
\hline 2012/13 & $\begin{array}{l}0.306 \\
(0.02)\end{array}$ & $\begin{array}{l}0.467 \\
(0.02)\end{array}$ & $\begin{array}{l}0.216 \\
(0.01)\end{array}$ & & \\
\hline
\end{tabular}

Notes: Northern Ireland is included in the FRS and hence HBAI data only from 2002/03 onwards. Source: Authors' calculations based on HBAI, FRS, SPI and WTID data. Household income is equivalised using the modified-OECD scale. The individual is the unit of analysis. Estimates are based on the full population. 
Table G.4 Half-squared coefficient of variation and standard errors within parentheses

\begin{tabular}{|c|c|c|c|c|c|}
\hline Data set & $\begin{array}{l}\text { HBAI- } \\
\text { SPI }\end{array}$ & $\begin{array}{l}\text { HBAI- } \\
\text { SPI }\end{array}$ & $\begin{array}{l}\text { HBAI- } \\
\text { SPI }\end{array}$ & $\begin{array}{l}\text { HBAI- } \\
\text { SPI2 }\end{array}$ & $\begin{array}{l}\text { HBAI- } \\
\text { SPI2 }\end{array}$ \\
\hline $\begin{array}{l}\text { Income } \\
\text { definition }\end{array}$ & $\begin{array}{l}\text { Gross } \\
\text { income }\end{array}$ & $\begin{array}{l}\text { Market } \\
\text { income }\end{array}$ & $\begin{array}{c}\text { Net } \\
\text { income }\end{array}$ & $\begin{array}{l}\text { Gross } \\
\text { income }\end{array}$ & $\begin{array}{l}\text { Market } \\
\text { income }\end{array}$ \\
\hline & (1) & (2) & (3) & (4) & (5) \\
\hline $1994 / 95$ & $\begin{array}{l}0.431 \\
(0.02)\end{array}$ & $\begin{array}{l}0.610 \\
(0.03)\end{array}$ & $\begin{array}{l}0.314 \\
(0.01)\end{array}$ & & \\
\hline $1995 / 96$ & $\begin{array}{l}0.470 \\
(0.03)\end{array}$ & $\begin{array}{l}0.645 \\
(0.04)\end{array}$ & $\begin{array}{l}0.330 \\
(0.02)\end{array}$ & $\begin{array}{l}0.486 \\
(0.03)\end{array}$ & $\begin{array}{l}0.661 \\
(0.04)\end{array}$ \\
\hline 1996/97 & $\begin{array}{l}0.444 \\
(0.02)\end{array}$ & $\begin{array}{l}0.614 \\
(0.03)\end{array}$ & $\begin{array}{l}0.321 \\
(0.02)\end{array}$ & $\begin{array}{l}0.594 \\
(0.04)\end{array}$ & $\begin{array}{l}0.795 \\
(0.05)\end{array}$ \\
\hline 1997/98 & $\begin{array}{l}0.565 \\
(0.04)\end{array}$ & $\begin{array}{l}0.751 \\
(0.05)\end{array}$ & $\begin{array}{l}0.390 \\
(0.03)\end{array}$ & $\begin{array}{l}0.637 \\
(0.05)\end{array}$ & $\begin{array}{l}0.835 \\
(0.06)\end{array}$ \\
\hline 1998/99 & $\begin{array}{l}0.642 \\
(0.07)\end{array}$ & $\begin{array}{l}0.843 \\
(0.09)\end{array}$ & $\begin{array}{l}0.461 \\
(0.05)\end{array}$ & $\begin{array}{l}0.717 \\
(0.06)\end{array}$ & $\begin{array}{l}0.929 \\
(0.08)\end{array}$ \\
\hline 1999/00 & $\begin{array}{l}0.667 \\
(0.06)\end{array}$ & $\begin{array}{l}0.876 \\
(0.08)\end{array}$ & $\begin{array}{l}0.463 \\
(0.04)\end{array}$ & $\begin{array}{l}0.763 \\
(0.06)\end{array}$ & $\begin{array}{l}0.985 \\
(0.07)\end{array}$ \\
\hline 2000/01 & $\begin{array}{l}0.712 \\
(0.05)\end{array}$ & $\begin{array}{l}0.935 \\
(0.07)\end{array}$ & $\begin{array}{l}0.505 \\
(0.04)\end{array}$ & $\begin{array}{l}0.805 \\
(0.07)\end{array}$ & $\begin{array}{l}1.043 \\
(0.08)\end{array}$ \\
\hline $2001 / 02$ & $\begin{array}{l}0.765 \\
(0.08)\end{array}$ & $\begin{array}{l}1.003 \\
(0.09)\end{array}$ & $\begin{array}{l}0.527 \\
(0.05)\end{array}$ & $\begin{array}{l}0.777 \\
(0.07)\end{array}$ & $\begin{array}{l}1.011 \\
(0.08)\end{array}$ \\
\hline $2002 / 03$ & $\begin{array}{l}0.679 \\
(0.06)\end{array}$ & $\begin{array}{l}0.908 \\
(0.07)\end{array}$ & $\begin{array}{l}0.466 \\
(0.04)\end{array}$ & $\begin{array}{l}0.659 \\
(0.05)\end{array}$ & $\begin{array}{l}0.877 \\
(0.06)\end{array}$ \\
\hline $2003 / 04$ & $\begin{array}{l}0.620 \\
(0.06)\end{array}$ & $\begin{array}{l}0.850 \\
(0.08)\end{array}$ & $\begin{array}{l}0.441 \\
(0.04)\end{array}$ & $\begin{array}{l}0.697 \\
(0.06)\end{array}$ & $\begin{array}{l}0.941 \\
(0.07)\end{array}$ \\
\hline $2004 / 05$ & $\begin{array}{l}0.619 \\
(0.04)\end{array}$ & $\begin{array}{l}0.844 \\
(0.06)\end{array}$ & $\begin{array}{l}0.430 \\
(0.03)\end{array}$ & $\begin{array}{l}0.721 \\
(0.06)\end{array}$ & $\begin{array}{l}0.967 \\
(0.07)\end{array}$ \\
\hline $2005 / 06$ & $\begin{array}{l}0.635 \\
(0.05)\end{array}$ & $\begin{array}{l}0.865 \\
(0.06)\end{array}$ & $\begin{array}{l}0.458 \\
(0.04)\end{array}$ & $\begin{array}{l}0.894 \\
(0.07)\end{array}$ & $\begin{array}{l}1.177 \\
(0.09)\end{array}$ \\
\hline $2006 / 07$ & $\begin{array}{l}0.661 \\
(0.06)\end{array}$ & $\begin{array}{l}0.882 \\
(0.08)\end{array}$ & $\begin{array}{l}0.471 \\
(0.04)\end{array}$ & $\begin{array}{l}1.074 \\
(0.14)\end{array}$ & $\begin{array}{l}1.381 \\
(0.16)\end{array}$ \\
\hline $2007 / 08$ & $\begin{array}{l}0.705 \\
(0.06)\end{array}$ & $\begin{array}{l}0.934 \\
(0.07)\end{array}$ & $\begin{array}{l}0.501 \\
(0.04)\end{array}$ & $\begin{array}{l}1.162 \\
(0.15)\end{array}$ & $\begin{array}{l}1.485 \\
(0.18)\end{array}$ \\
\hline 2008/09 & $\begin{array}{l}0.746 \\
(0.07)\end{array}$ & $\begin{array}{l}1.002 \\
(0.08)\end{array}$ & $\begin{array}{l}0.514 \\
(0.04)\end{array}$ & & \\
\hline $2009 / 10$ & $\begin{array}{l}0.757 \\
(0.06)\end{array}$ & $\begin{array}{l}1.031 \\
(0.08)\end{array}$ & $\begin{array}{l}0.501 \\
(0.04)\end{array}$ & $\begin{array}{l}1.214 \\
(0.14)\end{array}$ & $\begin{array}{l}1.607 \\
(0.17)\end{array}$ \\
\hline 2010/11 & $\begin{array}{l}0.620 \\
(0.04)\end{array}$ & $\begin{array}{l}0.869 \\
(0.06)\end{array}$ & $\begin{array}{l}0.378 \\
(0.02)\end{array}$ & $\begin{array}{l}0.842 \\
(0.09)\end{array}$ & $\begin{array}{l}1.150 \\
(0.12)\end{array}$ \\
\hline $2011 / 12$ & $\begin{array}{l}0.715 \\
(0.07)\end{array}$ & $\begin{array}{l}0.984 \\
(0.09)\end{array}$ & $\begin{array}{l}0.412 \\
(0.04)\end{array}$ & & \\
\hline $2012 / 13$ & $\begin{array}{l}0.578 \\
(0.05)\end{array}$ & $\begin{array}{l}0.802 \\
(0.06)\end{array}$ & $\begin{array}{l}0.350 \\
(0.03)\end{array}$ & & \\
\hline
\end{tabular}

Notes: Northern Ireland is included in the FRS and hence HBAI data only from 2002/03 onwards. Source: Authors' calculations based on HBAI, FRS, SPI and WTID data. Household income is equivalised using the modified-OECD scale. The individual is the unit of analysis. Estimates are based on the full population. 